Prepared in cooperation with the National Park Service

\title{
Spring Types and Contributing Aquifers from Water-Chemistry and Multivariate Statistical Analyses for Seeps and Springs in Theodore Roosevelt National Park, North Dakota, 2018
}

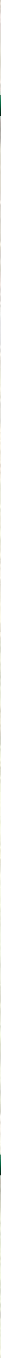

U.S. Department of the Interior U.S. Geological Survey 
Cover: Left photograph: Overlook Spring in the North Unit of Theodore Roosevelt National Park, taken May 22, 2018, by Jeff Hughes, U.S. National Park Service.

Right photograph: Stevens Spring in the North Unit of Theodore Roosevelt National Park, taken September 21, 2018, by Bill Eldridge, U.S. Geological Survey, Dakota Water Science Center.

Lower photograph: National Park Service personnel sampling a seep at Sheep Butte Spring in the South Unit of Theodore Roosevelt National Park, taken September 21, 2018, by Bill Eldridge, U.S. Geological Survey, Dakota Water Science Center. 


\section{Spring Types and Contributing Aquifers from Water-Chemistry and Multivariate Statistical Analyses for Seeps and Springs in Theodore Roosevelt National Park, North Dakota, 2018}

By Colton J. Medler and William G. Eldridge

Prepared in cooperation with the National Park Service

Scientific Investigations Report 2020-5121 


\section{U.S. Geological Survey, Reston, Virginia: 2021}

For more information on the USGS - the Federal source for science about the Earth, its natural and living resources, natural hazards, and the environment—visit https://www.usgs.gov or call 1-888-ASK-USGS.

For an overview of USGS information products, including maps, imagery, and publications, visit https://store.usgs.gov/.

Any use of trade, firm, or product names is for descriptive purposes only and does not imply endorsement by the U.S. Government.

Although this information product, for the most part, is in the public domain, it also may contain copyrighted materials as noted in the text. Permission to reproduce copyrighted items must be secured from the copyright owner.

Suggested citation:

Medler, C.J., and Eldridge, W.G., 2021, Spring types and contributing aquifers from water-chemistry and multivariate statistical analyses for seeps and springs in Theodore Roosevelt National Park, North Dakota, 2018: U.S. Geological Survey Scientific Investigations Report 2020-5121, 48 p., https://doi.org/10.3133/sir20205121.

Associated data for this publication:

U.S. Geological Survey, 2020, USGS water data for the Nation: U.S. Geological Survey National Water Information System database, https://doi.org/10.5066/F7P55KJN.

ISSN 2328-0328 (online) 


\section{Acknowledgments}

Funding for this study was provided by the National Park Service. The authors acknowledge the efforts of several people who contributed to this study. Most importantly, the staff of Theodore Roosevelt National Park assisted with site visits, access to records, and background information for wells, springs, and seeps. Staff from the National Park Service, Water Resources Division, also assisted with site visits, provided access to documents, and provided a thorough review of this report.

The authors also thank the U.S. Geological Survey reviewers for their careful reviews of this report. Their comments greatly improved the accuracy and readability of this report. 



\section{Contents}

Acknowledgments ……...................................................................................................................

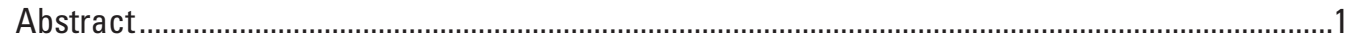

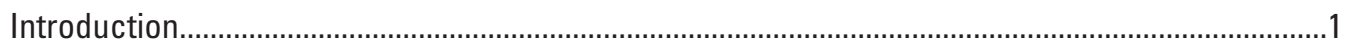

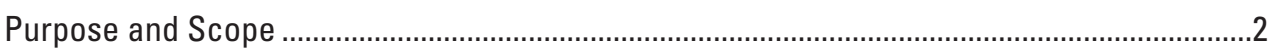

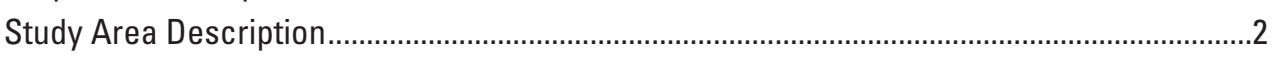

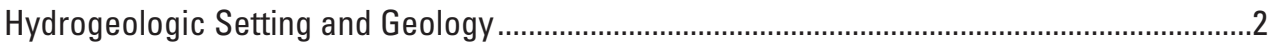

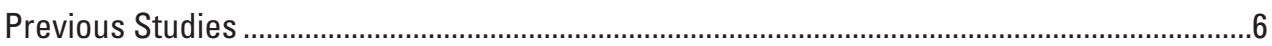

Methods for Sample Collection and Water-Chemistry Data Analysis ...............................................6

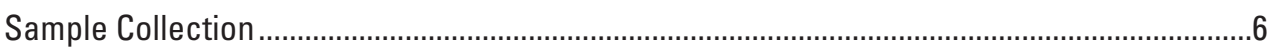

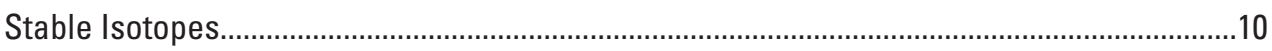

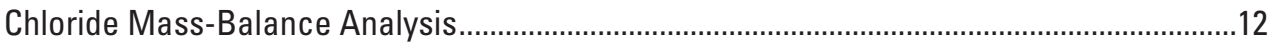

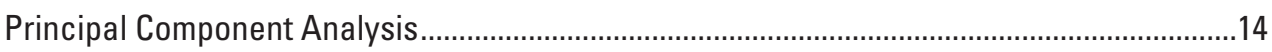

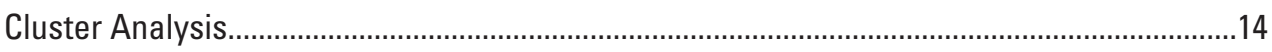

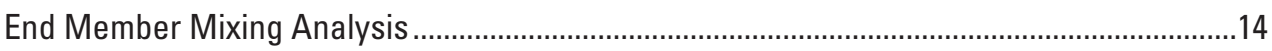

Water-Chemistry and Multivariate Statistical Analyses ...........................................................15

Comparisons to Meteoric Conditions and Sampling Site Evaluations using Stable

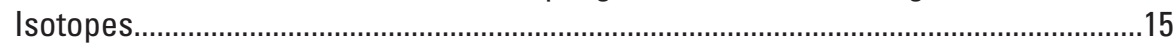

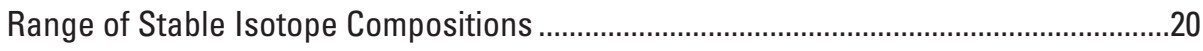

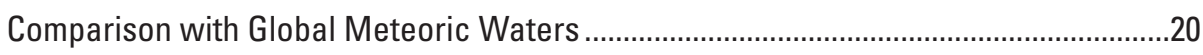

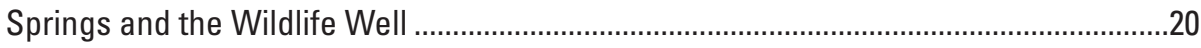

Upper Fort Union and Fox Hills-Lower Hell Creek Aquifers...............................................24

Streams and Rain Collectors ...............................................................................24

Recharge Rate and Percent Recharge Estimates from Chloride Mass Balance ...................25

Site Groupings and Water Sources from Principal Component Analysis ...............................29

Cluster Assignments and Water Sources from Cluster Analysis ............................................30

Groundwater and Precipitation Contributions from End Member Mixing Analysis ................32

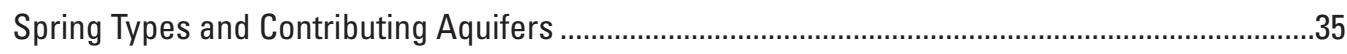

North Unit Spring Types and Contributing Aquifers..............................................................35

South Unit Spring Types and Contributing Aquifers.................................................................35

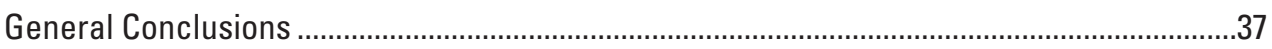

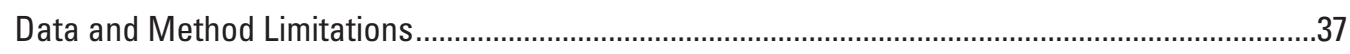

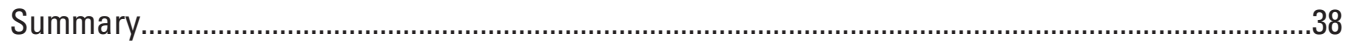

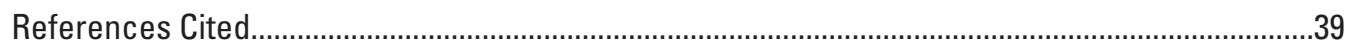

Appendix 1. Principal Component Analysis and Cluster Analysis with Water-Chemistry

Data from a 1980s National Park Service Study in Theodore Roosevelt National Park.....44 


\section{Figures}

1. Map showing Theodore Roosevelt National Park including the North Unit, Elkhorn Ranch Unit, and South Unit in southwestern North Dakota.

2. Stratigraphic columnar section showing generalized geologic units in Theodore Roosevelt National Park listing the era, system, group, formation, maximum thickness, description and lithology, and generalized hydrogeologic unit ......4

3. Diagram showing types of springs in the study area

4. Maps showing springs, streams, wells, and rain collectors sampled in Theodore Roosevelt National Park

5. Graph showing the effects of hydrologic processes on the oxygen and hydrogen isotopic composition of water...

6. Graph showing a 12-day lag time from May 1 to October 1, 2018, between the cumulative precipitation curve for the National Oceanic and Atmospheric Administration Taylor 7 NNWS climate station and water levels in a well completed in an unconfined part of the upper Fort Union near Dickinson, North Dakota

7. Graph showing a stable isotope plot of water samples collected in May 2018 in Theodore Roosevelt National Park

8. Graph showing a stable isotope plot of water samples collected in June and July 2018 in Theodore Roosevelt National Park

9. Graph showing a stable isotope plot of water samples collected in August and September 2018 in Theodore Roosevelt National Park.

10. Graphs showing the 12-day recharge rate and 12-day percent recharge estimates from the chloride mass-balance method for springs and the Wildlife Well (NU_WldlfW)

11. Graph showing a principal component analysis biplot of water-chemistry data with loading lines for each variable label used in the analysis

12. Graph showing the $k$-means procedure applied to the principal component analysis biplot in figure 11 of water-chemistry data with colors symbolizing the five cluster assignment groups

13. Graph showing the end member mixing analysis results for samples from springs and the Wildlife well expressed as mean percentages of upper Fort Union aquifer groundwater and precipitation

14. Graph showing the end member mixing analysis results for samples from springs and the Wildlife well expressed as percentages of upper Fort Union aquifer groundwater by month.

\section{Tables}

1. Summary of site information, including site number, site name, short name, location, elevation, elevation accuracy, depth to well bottom, and sample category, for water samples collected in Theodore Roosevelt National Park, 2018 ........8

2. Primary and replicate sample data for select sites in the North and South Units of Theodore Roosevelt National Park

3. Summary of water-chemistry results for samples collected from springs, streams, wells, and rain collectors in Theodore Roosevelt National Park, North Dakota 
4. Summary of chloride-mass balance results, including the 12-day recharge rate, 12-day percent recharge, and annual recharge rate estimates for springs and one alluvial well

5. Summary of cluster analysis results listing groups, sampling site names, sampling site short names, and categories from the $k$-means clustering procedure applied to principal component analysis results.

6. Summary of multivariate statistical analyses results with geologic setting, spring, type, and aquifer type for springs in the North and South Units of Theodore Roosevelt National Park.

\section{Conversion Factors}

U.S. customary units to International System of Units

\begin{tabular}{lcl}
\hline & \multicolumn{1}{c}{ Multiply } & \multicolumn{1}{c}{ Bo obtain } \\
\hline inch (in.) & Length & \\
inch (in.) & 2.54 & centimeter (cm) \\
foot (ft) & 25.4 & millimeter (mm) \\
mile (mi) & 0.3048 & meter (m) \\
& 1.609 & kilometer (km) \\
\hline inch per year (in/yr) & Flow rate & \\
\hline
\end{tabular}

Temperature in degrees Celsius $\left({ }^{\circ} \mathrm{C}\right)$ may be converted to degrees Fahrenheit $\left({ }^{\circ} \mathrm{F}\right)$ as follows:

$$
{ }^{\circ} \mathrm{F}=\left(1.8 \times{ }^{\circ} \mathrm{C}\right)+32 .
$$

\section{Datum}

Vertical coordinate information is referenced to the North American Vertical Datum of 1988 (NAVD 88).

Horizontal coordinate information is referenced to the North American Datum of 1983 (NAD 83).

Altitude, as used in this report, refers to distance above the vertical datum.

\section{Supplemental Information}

Specific conductance is given in microsiemens per centimeter at 25 degrees Celsius $(\mu \mathrm{S} / \mathrm{cm}$ at $\left.25^{\circ} \mathrm{C}\right)$.

Concentrations of chemical constituents in water are given in milligrams per liter (mg/L).

Stable isotope ratios of oxygen $(180 / 160)$ and hydrogen $(2 \mathrm{H} / 1 \mathrm{H})$ are shown in delta $(\delta)$ notation as $\delta^{180}$ and $\delta^{2} \mathrm{H}$, in parts per thousand $(\%)$. 
viii

\section{Abbreviations}

$\begin{array}{ll}\text { CMB } & \text { chloride mass balance } \\ \text { EMMA } & \text { end-member mixing analysis } \\ \text { GMWL } & \text { global meteoric water line } \\ \text { LMWL } & \text { local meteoric water line } \\ \text { NADP } & \text { National Atmospheric Deposition Program } \\ \text { NOAA } & \text { National Oceanic and Atmospheric Administration } \\ \text { PCA } & \text { principal component analysis } \\ \text { RPD } & \text { relative percent difference } \\ \text { USGS } & \text { U.S. Geological Survey }\end{array}$




\title{
Spring Types and Contributing Aquifers from Water-Chemistry and Multivariate Statistical Analyses for Seeps and Springs in Theodore Roosevelt National Park, North Dakota, 2018
}

\author{
By Colton J. Medler and William G. Eldridge
}

\section{Abstract}

Water resources in Theodore Roosevelt National Park, North Dakota, support wildlife, visitors, and staff, and play a vital role in supporting the native ecology of the park. The U.S. Geological Survey, in cooperation with the National Park Service, completed field work in 2018 for a study to address concerns about water availability and possible sources of groundwater contamination for seeps and springs in Theodore Roosevelt National Park. The objective of the study was to improve hydrologic knowledge and determine the water composition of 11 seeps and springs in the park by collecting water-chemistry data at springs, streams, wells, and rain collectors.

Water samples were collected at 26 sites at springs, streams, wells, and rain collectors in the North and South Units of Theodore Roosevelt National Park. Samples in the North Unit were collected at 5 springs, 1 stream, 2 wells, and 1 rain collector. Samples in the South Unit were collected at 6 springs, 2 streams, 8 wells, and 1 rain collector. Samples from springs, streams, and wells were collected in May, July, and September 2018. Samples from rain collectors were collected when enough daily precipitation accumulated in the collectors. Sampled precipitation events during the study period were in May, June, July, August, and September 2018. Physical properties of sampled water-temperature, $\mathrm{pH}$, and specific conductance - were measured in the field. Water samples were analyzed for stable isotopes of oxygen and hydrogen and for chloride concentration. Recharge rates for aquifers supplying springs were determined using precipitation volume and chloride concentrations for a 12-day period before the sample-collection date. Multivariate statistical analysis methods used on water-chemistry data included principal component analysis, cluster analysis, and end-member mixing analysis.

Water composition was used to determine the spring type and contributing aquifers for 11 springs in the North and South Units of Theodore Roosevelt National Park from analyses of water-chemistry data between May and September 2018. In the North Unit, Achenbach Spring was classified as a filtration spring with water from an unconfined part of the upper Fort Union aquifer and infiltration of precipitation. Hagen Spring, Mandal Spring, and Stevens Spring were classified as contact springs supplied by semiconfined parts of the upper Fort Union aquifer. Overlook Spring at one time may have been a natural spring or seep but now is a developed spring that behaves like a flowing artesian well completed in a confined part of the upper Fort Union aquifer. In the South Unit, six springs were classified into two spring types: filtration and contact springs. Boicourt Spring and Sheep Butte Spring were classified as filtration springs that have water supplied by unconfined parts of the upper Fort Union aquifer and infiltrated precipitation. Big Plateau Spring, Lone Tree Spring, Sheep Pasture Spring, and Southeast Corner Spring were classified as contact springs that receive waters from a semiconfined part of the upper Fort Union aquifer.

\section{Introduction}

Water resources in Theodore Roosevelt National Park, North Dakota, support wildlife, visitors, and staff while also playing a vital role in supporting the native ecology of the park. Beginning in the late 1970s, demand for water at sites near the park increased because of oil and gas development and ethanol production (Eldridge and Medler, 2020). The increased water demand may affect the availability of freshwater in the region used for park operations. Surface waters, including seeps and springs, are the primary water resources for Theodore Roosevelt National Park (National Park Service, 2014). The aquifers supplying seeps and springs in the park, however, may be vulnerable to groundwater withdrawals, drought conditions, changes in evapotranspiration rates (Griffin and Friedman, 2017), and contamination-making seeps and springs, as well as contributing aquifers, a priority for protection. 
The National Park Service has concerns regarding water availability and possible sources of groundwater contamination for seeps and springs in Theodore Roosevelt National Park. The U.S. Geological Survey, in cooperation with the National Park Service, completed field work in 2018 for a study to address these concerns. The goals of the study were to improve hydrologic knowledge and determine the water composition of 11 seeps and springs in the park by collecting water-chemistry data at springs, streams, wells, and rain collectors. Water-chemistry data included physical properties, stable isotopes of oxygen and hydrogen, and chloride concentrations. Water-chemistry results, combined with multivariate statistical analysis methods, were used to achieve the study goals by qualitatively and quantitatively analyzing waterchemistry data for patterns and groupings at 26 total sites in the North and South Units of the park. The results of the study may assist park managers with protecting springs and seeps in Theodore Roosevelt National Park.

\section{Purpose and Scope}

The purpose of this report is to describe the spring types and contributing aquifers in Theodore Roosevelt National Park. This report provides a summary of the methods and results used to improve hydrologic knowledge of 11 springs and seeps in Theodore Roosevelt National Park. Hydrologic characteristics of springs in the park were determined from analysis of water-chemistry data collected between May and September 2018 from springs, streams, wells, and rain collectors in Theodore Roosevelt National Park. Stable isotopes of oxygen and hydrogen were used to compare park waters to the global annual mean of meteoric waters, as well as to compare isotopic compositions among sites. Chloride concentrations were used to determine recharge characteristics through the chloride mass-balance (CMB) method. Multivariate statistical analysis methods, including principal component analysis (PCA), $k$-means clustering, and end-member mixing analysis (EMMA), were used on all water-chemistry data to highlight relations among sites and group sites into hydrologically similar clusters. The water-chemistry patterns and multivariate statistical method results, in conjunction with information about precipitation and hydrogeologic units in Theodore Roosevelt National Park, were used to determine spring type and identify supplying aquifers for all 11 springs.

\section{Study Area Description}

Theodore Roosevelt National Park is in southwestern North Dakota, in McKenzie and Billings Counties, and consists of three separate units: the North Unit, Elkhorn Ranch Unit, and the South Unit (fig. 1). The three park units are largely contained within the Little Missouri River watershed (fig. 1) - a semiarid continental environment with badlandtype topography. Bluemle (1977) described the badlands of the Little Missouri drainage basin as steep, hilly topography formed from deep erosion by the Little Missouri River and its tributaries. The Little Missouri River flows north through the South Unit, adjacent to the Elkhorn Ranch Unit, and bends eastward in the North Unit before discharging into the Missouri River (fig. 1). Theodore Roosevelt National Park contains 21 miles (mi) of the Little Missouri River and $269 \mathrm{mi}$ of intermittent streams (Amberg and others, 2014). The study area included only the North and South Units.

\section{Hydrogeologic Setting and Geology}

The hydrogeologic setting and geology of Theodore Roosevelt National Park are important for identifying aquifers supplying seeps and springs within the park. The park is near the center of the Williston Basin - a large, roughly circular depression underlying parts of North Dakota, South Dakota, Montana, and Canada (Pollastro and others, 2013; fig. 1). The Williston Basin is filled with a nearly complete sequence of Phanerozoic sedimentary rocks that can exceed 16,000 feet (ft) in thickness (Anna and others, 2013). Groundwater in aquifers underlying the Cretaceous-age Pierre Shale (fig. 2) in the basin typically are not suitable for human consumption (Croft, 1985). The Pierre Shale acts as a low permeability layer between underlying aquifers and groundwater sources for seeps and springs in the park because of its 1,700 to 2,300 ft thickness (Sandberg, 1962) and its largely impermeable composition of mostly shale and siltstone (Murphy and others, 2009). Geologic units overlying the Pierre Shale contain three major aquifers: the upper Fort Union aquifer, the lower Fort Union aquifer, and the Fox Hills-lower Hell Creek aquifer (fig. 2). The upper Fort Union aquifer and lower Fort Union aquifer are contained in the Tertiary-age Fort Union Formation, and the Fox Hills-lower Hell Creek aquifer is contained in the Cretaceous-age Fox Hills Sandstone and the Hell Creek Formation. Geologic maps from Biek and Gonzalez (2001) showed geologic exposures in the North and South Units of the park are upper Fort Union aquifer materials from the Sentinel Butte and Bullion Creek Formations. Additionally, low-permeability beds of bentonite, clinker, and lignite in the Sentinel Butte and Bullion Creek Formations were mapped in both units of the park. The presence of both permeable and impermeable geologic units in these formations, combined with steep topography, provide ideal conditions for spring and seep formation.

As early as 1929, the hydrogeology in the region around Theodore Roosevelt National Park was noted for its ability to form springs and seeps (Simpson and Riffenburg, 1929). Springs are defined as places where water naturally issues from the ground and flows or forms pools (Bryan, 1919). Springs commonly form when the side of a hill, a valley bottom, or other excavations intersect flowing groundwater at or below the local water table (U.S. Geological Survey, 2019). Seeps are a type of spring in which the water flows from pores in the ground over considerable areas (Bryan, 1919). Seeps occur from a slow movement of water through 


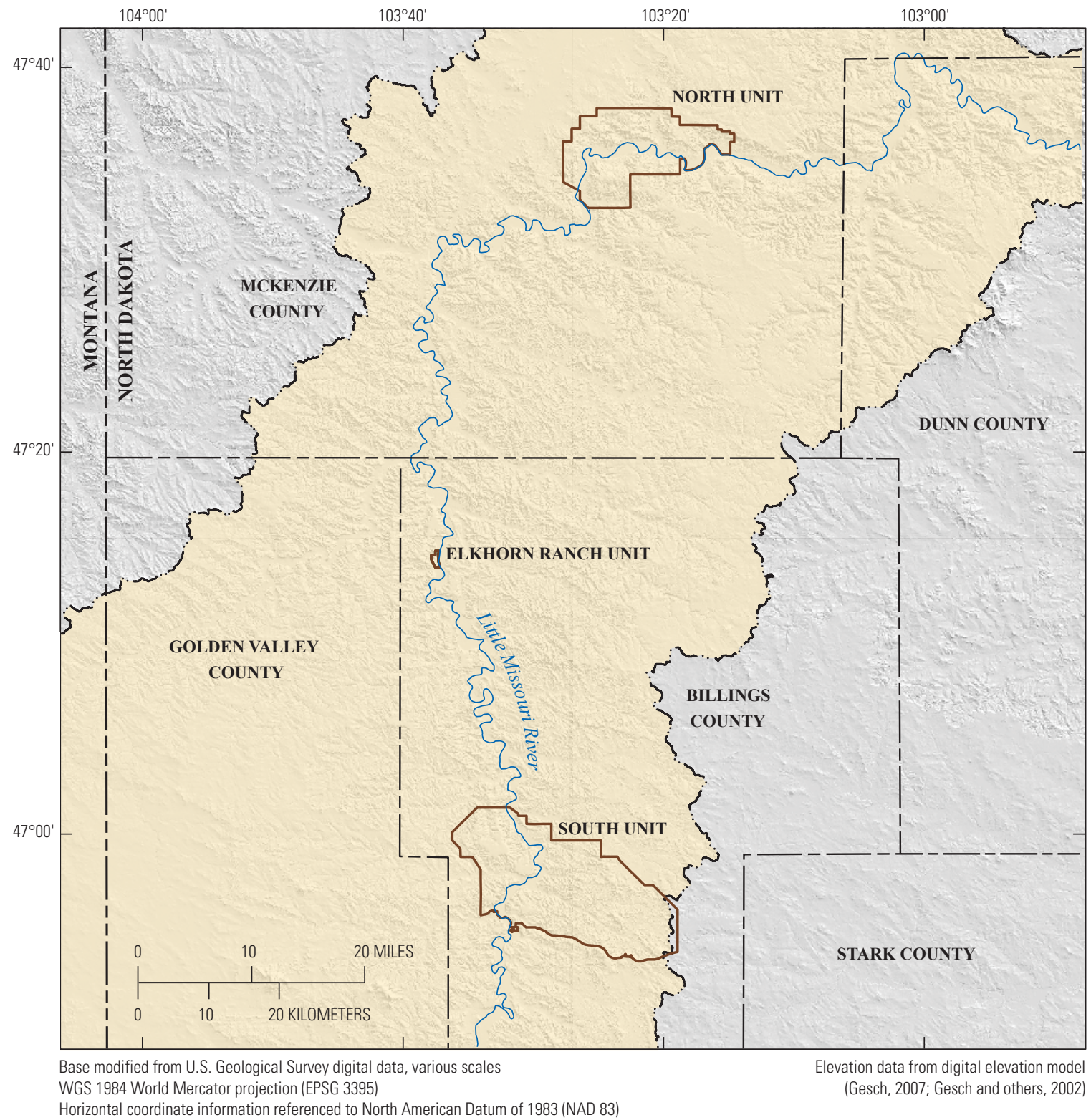

EXPLANATION
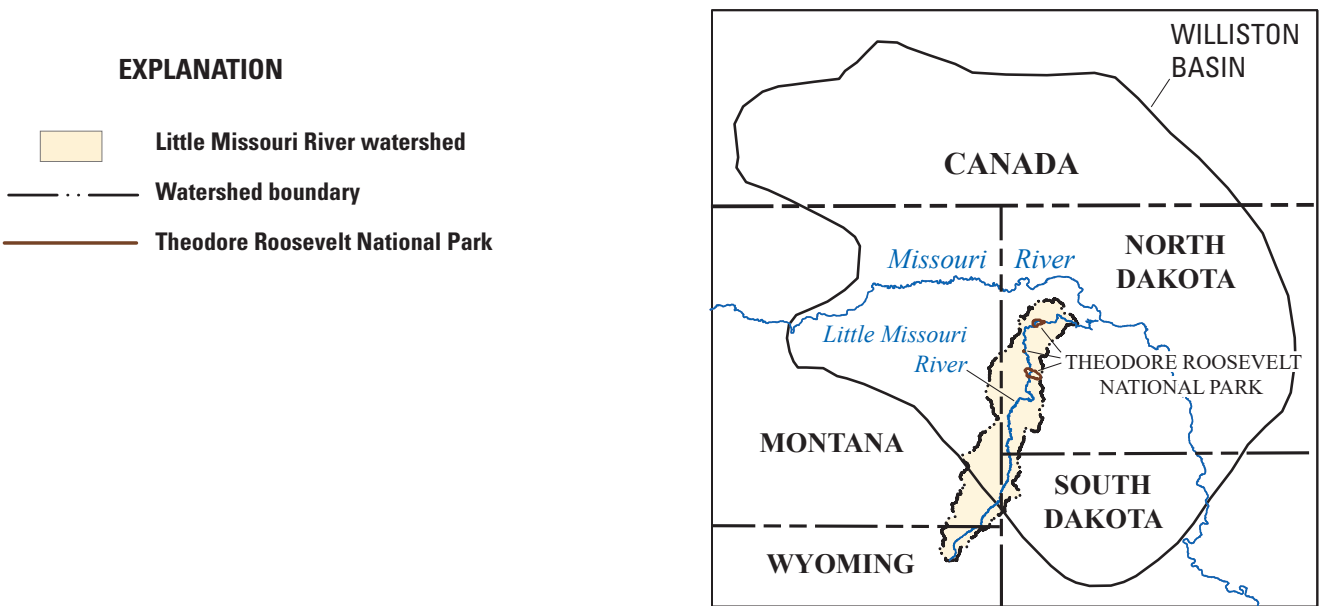

Figure 1. Theodore Roosevelt National Park including the North Unit, Elkhorn Ranch Unit, and South Unit in southwestern North Dakota. The study area included only the North and South Units. 


\begin{tabular}{|c|c|c|c|c|c|c|}
\hline Era & System & Group & Formation & $\begin{array}{l}\text { Maximum } \\
\text { thickness, } \\
\text { in feet }\end{array}$ & Description and lithology & $\begin{array}{l}\text { Generalized } \\
\text { hydrogeologic unit }\end{array}$ \\
\hline \multirow{14}{*}{ 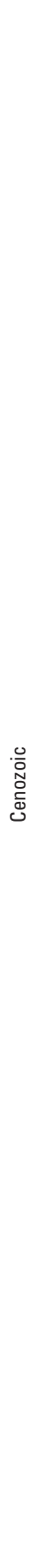 } & \multirow{3}{*}{ Quaternary } & & & Variable & $\begin{array}{l}\text { Sand, gravel, silt, and clay from locally derived sources, such } \\
\text { as weathering of consolidated rock and terrace gravels }\end{array}$ & Alluvial/surficial deposits \\
\hline & & & Oahe Formation & 100 & $\begin{array}{l}\text { Oahe Formation: tan to gray to black clay, silt, sand, and } \\
\text { gravel; organic rich or organic-rich lenses; pebbles consisting } \\
\text { of clinker and lignite fragments; paleosols }\end{array}$ & \multirow{8}{*}{$\begin{array}{l}\text { Not an important source of } \\
\text { groundwater in the study area }\end{array}$} \\
\hline & & Coleharbor & $\begin{array}{l}\text { See Murphy and others (2009) } \\
\text { for a complete list }\end{array}$ & 1,000 & $\begin{array}{l}\text { Coleharbor Group: olive gray to tan clay, silt, sand, gravel, and } \\
\text { boulders; glacial till; glaciolacustrine clays; organic rich; plant } \\
\text { and animal remains }\end{array}$ & \\
\hline & \multirow{11}{*}{ Tertiary } & & Unnamed units & 300 & $\begin{array}{l}\text { Gravel, sand, sandstone, silicified wood, concretions; mainly } \\
\text { pebbles and cobbles; clay, silt, sand, and gravel }\end{array}$ & \\
\hline & & & Arikaree Formation & 330 & $\begin{array}{l}\text { Light gray, green, white limestone, sandstone, and siltstone; } \\
\text { tuffaceous; green chert nodules in marlstone; contains the } \\
\text { burrowed marker unit }\end{array}$ & \\
\hline & & & Brule Formation & 200 & $\begin{array}{l}\text { Brown to pink siltstone, sandstone, and claystone; nodular } \\
\text { siltstones may contain claystone inclusions; mammal fossils } \\
\text { common }\end{array}$ & \\
\hline & & \multirow[t]{3}{*}{ White River } & \multirow[b]{2}{*}{ Chadron Formation } & \multirow[b]{2}{*}{ 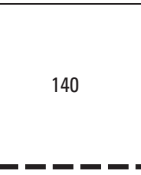 } & $\begin{array}{l}\text { Top: brown, pink, and green claystone; contains silicified } \\
\text { zones; bentonitic; popcorn weathering surface }\end{array}$ & \\
\hline & & & & & $\begin{array}{l}\text { Bottom: grayish green to white sandstone and conglomerate; } \\
\text { cross-bedded, poorly cemented sandstone; pebbles include } \\
\text { volcanic porphyries, quartz, and some petrified wood } \\
\text { Top: yellow and brown sandstone, siltstone, mudstone, } \\
\text { laystone, and thin lignite; poorly to well-cemented sandstone; } \\
\text { micaceous }\end{array}$ & \\
\hline & & & Golden Valley Formation & 400 & $\begin{array}{l}\text { Bottom: white, gold, purple claystone, siltstone, and } \\
\text { sandstone; kaolinitic; small iron spheres }\end{array}$ & \\
\hline & & \multirow{5}{*}{ Fort Union } & Sentinel Butte Formation & 650 & $\begin{array}{l}\text { Gray, blue, and brown sandstone, siltstone, claystone, } \\
\text { mudstone, clinker, and lignite; poorly to well-cemented } \\
\text { sandstone; swelling bentonitic and nonswelling claystones; } \\
\text { limestone with nodules and concretions; petrified wood }\end{array}$ & \multirow{3}{*}{$\begin{array}{l}\text { Upper Fort Union } \\
\text { aquifer }\end{array}$} \\
\hline & & & Bullion Creek Formation ${ }^{1}$ & 650 & $\begin{array}{l}\text { Generally bright colored, yellow, brown, gray sandstone, } \\
\text { siltstone, claystone, mudstone, clinker, and lignite; poorly to } \\
\text { well-cemented sandstones; swelling and nonswelling } \\
\text { claystones; limestone with nodules and concretions }\end{array}$ & \\
\hline & & & Slope Formation ${ }^{2}$ & 270 & $\begin{array}{l}\text { Generally dark colored, brown and gray sandstone, siltstone, } \\
\text { claystone, mudstone, clinker, and lignite; poorly to well- } \\
\text { cemented sandstone, swelling and nonswelling claystones; } \\
\text { limestone with nodules and concretions }\end{array}$ & \\
\hline & & & Cannonball Formation & 255 & $\begin{array}{l}\text { Dark gray to black mudstone; greenish gray to yellow } \\
\text { sandstone; glauconitic; mudstone contains lenses of siltstone } \\
\text { and sandstone; poorly to well-cemented sandstone; } \\
\text { abudnant marine fossils }\end{array}$ & \multirow{3}{*}{$\begin{array}{l}\text { Lower Fort Union } \\
\quad \text { aquifer }\end{array}$} \\
\hline & & & Ludlow Formation ${ }^{3}$ & 300 & $\begin{array}{l}\text { Brown and gray sandstone, siltstone, claystone, mudstone, } \\
\text { clinker, and lignite; poorly cemented to well-cemented } \\
\text { sandstones; swelling and nonswelling claystones; limestone } \\
\text { with nodules and concretions }\end{array}$ & \\
\hline \multirow{4}{*}{ 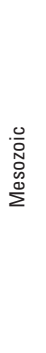 } & \multirow{4}{*}{ Cretaceous } & \multirow{4}{*}{ Montana } & \multirow{2}{*}{ Hell Creek Formation } & \multirow{2}{*}{330} & \multirow{2}{*}{$\begin{array}{l}\text { Gray, brown, and purple sandstone, siltstone, claystone, } \\
\text { mudstone and thin discontinuous lignite; moderately to poorly } \\
\text { cemented, organic rich, cross-bedded sandstone; bentonitic } \\
\text { claystone; tuffaceous beds, limestone with nodules, and } \\
\text { concretions; dinosaur fossils }\end{array}$} & \\
\hline & & & & & & \multirow[b]{2}{*}{$\begin{array}{l}\text { Fox Hills-lower Hell Creek } \\
\text { aquifer }\end{array}$} \\
\hline & & & Fox Hills Sandstone & 400 & $\begin{array}{l}\text { Yellowish brown to gray mudstone, siltstone, and sandstone; } \\
\text { poorly to well-cemented sandstone; organic laminae, } \\
\text { tuffaceous beds; abundant fossils }\end{array}$ & \\
\hline & & & Pierre Shale & 2,300 & $\begin{array}{l}\text { Light to dark gray shale, generally noncalcareous, and fissile } \\
\text { to blocky }\end{array}$ & $\begin{array}{l}\text { Not an important source of } \\
\text { groundwater in the study area }\end{array}$ \\
\hline
\end{tabular}

'Equivalent to Tongue River Formation pre-1977.

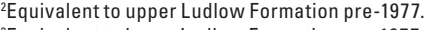

${ }^{3}$ Equivalent to lower Ludlow Formation pre-1977.

Figure 2. Generalized stratigraphic column of the geologic units in Theodore Roosevelt National Park listing the era, system, group, formation, maximum thickness, description and lithology, and generalized hydrogeologic unit. Modified from Eldridge and Medler (2020). 
small cracks, pores, or interstices of a material into or out of a body of surface or subsurface water (U.S. Geological Survey, 2019). Simpson and Riffenburg (1929) described porous beds of sandstone and lignite exposed at the land surface below the groundwater level in Billings County, N. Dak. (fig. 1), that provided the necessary hydrogeologic conditions to form springs. Reports summarized by the National Park Service (2011) described springs in the park as receiving their water from the upland prairie recharge areas surrounding the badlands or from remnants of the prairie within the badlands.

In Theodore Roosevelt National Park, the type of spring or seep can be identified by its contributing aquifer, geologic setting, and flow characteristics (fig. 3). Filtration springs and seeps (also called depression or dimple springs by Bryan, 1919) discharge groundwater from unconfined aquifers near steep terrain, along the sides of bluffs, or at the base of hills and depressions. Filtration springs receive water primarily from precipitation that flows through the aquifer to the spring. Discharge from filtration springs and seeps is intermittent and seasonal as the water table fluctuates with precipitation rates and frequency.
Contact springs (fig. 3; Bryan, 1919) form along lowpermeability units, such as the clinker deposits found in the Sentinel Butte Formation (fig. 2). The source of water for contact springs is unconfined aquifers, recharged by precipitation infiltrating downward until reaching a low-permeability unit and flowing along the low-permeability contact until reaching a point of discharge at the land surface (upper contact springs; fig. 3). Additionally, contact springs can form beneath a lowpermeability unit (lower contact springs; fig. 3) and receive waters from confined or semiconfined aquifers discharging near steep terrain, possibly near a slump or landslide (fig. 3).

Flowing artesian springs are formed when water from a confined aquifer percolates through a low permeability unit (fig. 3; Bryan, 1919; U.S. Geological Survey, 2019). The hydraulic head from artesian springs is above the land surface and equal to the hydraulic head of the confined aquifer at the location of the spring. Spring discharge rates from confined aquifers generally are more consistent than other spring types because of the volume of groundwater stored under pressure in confined aquifers (Bryan, 1919); however, groundwater withdrawals from wells completed in confined aquifers near

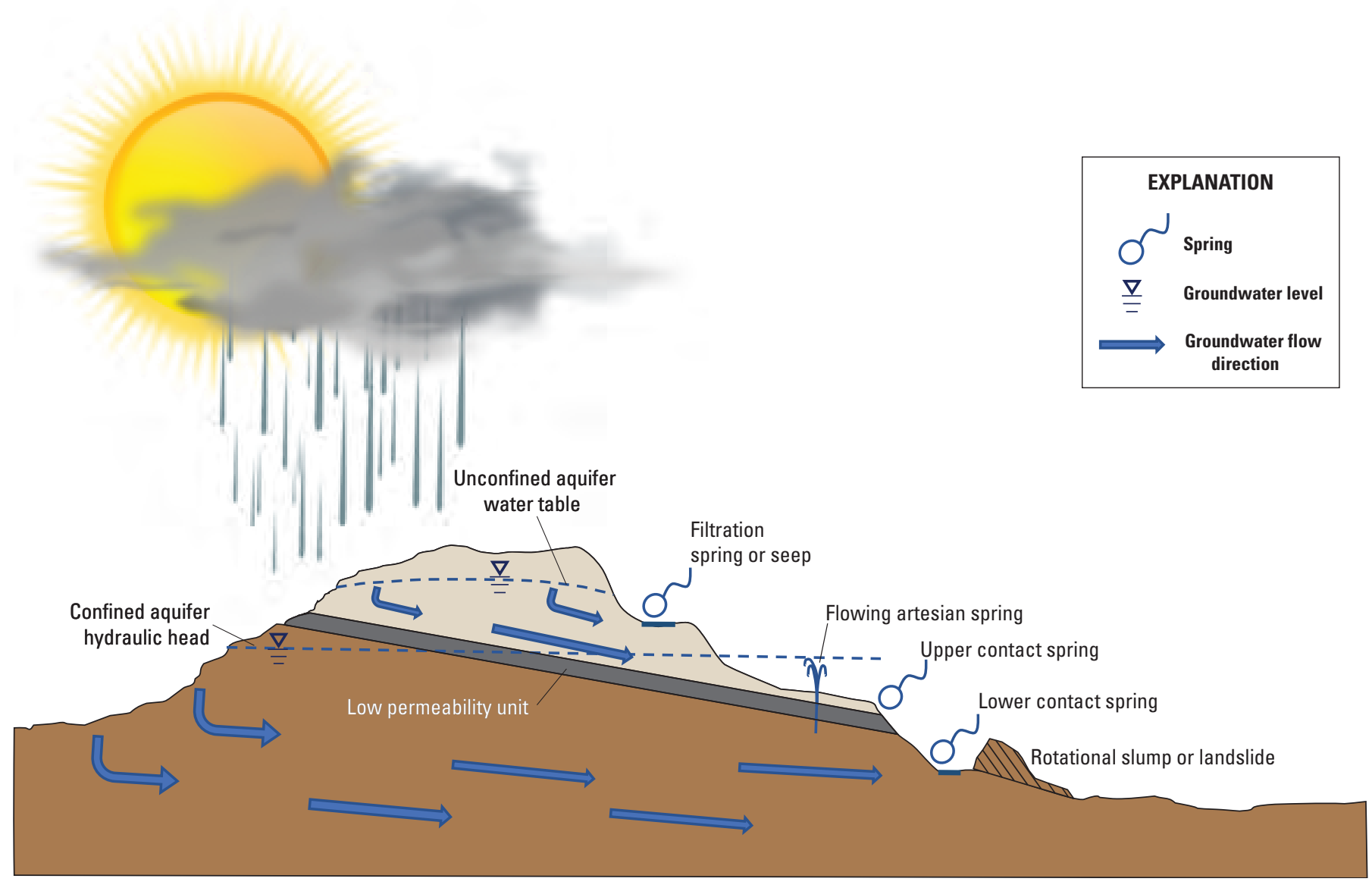

Figure 3. Types of springs in the study area. 
the spring can lower the hydraulic head of the aquifer and, in some circumstances, can lower the hydraulic head below the land surface causing artesian springs to cease flowing. Similarly, reduced recharge rates caused by higher evapotranspiration rates or changes in landcover that reduce the infiltration rate of precipitation to the aquifer also could decrease the discharge of flowing artesian springs.

\section{Previous Studies}

Several previous studies used water-chemistry data to improve hydrologic knowledge for seeps and springs across a range of geographic and geologic settings. Stable isotopes of oxygen and hydrogen were used to determine spring provenance (Mori and others, 2015; Stamm and McBride, 2016), to estimate the location of recharge areas (Blasch and Bryson, 2007; Kanduč and others, 2012), and to trace groundwater movement (Muir and Coplen, 1981). Greene (1997) and Naus and others (2001) used stable isotopes of oxygen and hydrogen in the Black Hills of South Dakota to trace groundwater flow paths in a karstic environment from sources of recharge to wells and springs several kilometers downgradient. The studies included water sampling, water-chemistry field property collection, hydrogeologic mapping, and additional water-chemistry characterization. Collected data were analyzed to determine spring water origins, group similar waters, and trace groundwater flow paths. Other studies used CMB to determine groundwater recharge rates in semiarid environments (Anderholm, 1994; McCoy and Blanchard, 2008) using assumptions provided by Dettinger (1989).

Previous studies also cataloged and described the springs and seeps in Theodore Roosevelt National Park. Anna (1981) described aquifers, surface water, and groundwater resources in the counties that contain the three park units. Discharge rates for springs in the park were measured in the 1980s and 1990s, but the measurements were not continuous and were recorded intermittently. Iierkley and others (1998) identified 16 springs in the park, 4 in the North Unit and 12 in the South Unit and noted that many other sites were not inventoried. Oehler and Sexton (2010) inventoried human-made water developments in the South Unit and included descriptions of seven wells and six springs and seeps used by wildlife. The National Park Service (2014) natural resources condition report for Theodore Roosevelt National Park listed 14 springs and seeps identified by park staff; 5 were in the North Unit, and 9 were in the South Unit. Additionally, the report states that low precipitation may cause water table decline, resulting in ceased flow for some springs.

\section{Methods for Sample Collection and Water-Chemistry Data Analysis}

Water samples from springs, streams, wells, and rain collectors were collected in the North and South Units of Theodore Roosevelt National Park (fig. 4). Stable isotope plots were constructed from stable isotope data collected at the sites. Recharge rates for aquifers supplying springs were determined using precipitation volume, and chloride concentrations were determined from precipitation and springs for a 12-day period before the sample collection. Multivariate statistical analysis methods used on water-chemistry data included PCA, cluster analysis, and EMMA. Water-chemistry data recorded by the National Park Service (1997), the National Oceanic and Atmospheric Association (NOAA, 2020), and the National Atmospheric Deposition Program (NADP, 2020) were used to supplement data collected during this study. The multivariate statistical analyses in this report used a similar approach as described in Long and Valder (2011) and Long and others (2012) to analyze water-chemistry data to determine spring types and identify aquifers supplying springs in the park.

\section{Sample Collection}

Water samples were collected at 26 sites at springs, streams, wells, and rain collectors in the North and South Units of Theodore Roosevelt National Park (table 1; fig. 4). Samples in the North Unit were collected at 5 springs, 1 stream, 2 wells, and 1 rain collector. In the South Unit, samples were collected at 6 springs, 2 streams, 8 wells, and 1 rain collector (table 1). Samples from springs, streams, and wells were collected in May, July, and September 2018. Samples from rain collectors were collected when enough daily precipitation accumulated in the collectors. Sampled precipitation events during the study period occurred in May, June, July, August, and September 2018.

Water samples were collected as grab samples using methods described in U.S. Geological Survey (variously dated). Physical properties of sampled water-temperature, $\mathrm{pH}$, and specific conductance - were measured in the field. Rain collectors used for precipitation sampling were "ballin-funnel" type (Michelsen and others, 2018), installed at two sites by National Park Service personnel, fixed about $6 \mathrm{ft}$ above the land surface in unobstructed areas. Water samples were analyzed for stable isotopes of oxygen (oxygen-18, $\delta^{18} \mathrm{O}$ ) and hydrogen (deuterium, $\left.\delta^{2} \mathrm{H}\right)$. Stable isotope samples were collected using 60-milliliter $(\mathrm{mL})$ glass bottles with Polyseal caps and stored at ambient temperature before laboratory analysis at the U.S. Geological Survey (USGS) Reston Stable Isotope Laboratory in Reston, Virginia. The laboratory methods used to determine stable isotope ratios are described by Révész and Coplen (2008a, 2008b). Chloride samples were collected using a $250-\mathrm{mL}$ polyethylene bottle rinsed and filled with a sample passed through a 0.45 -micrometer filter. 

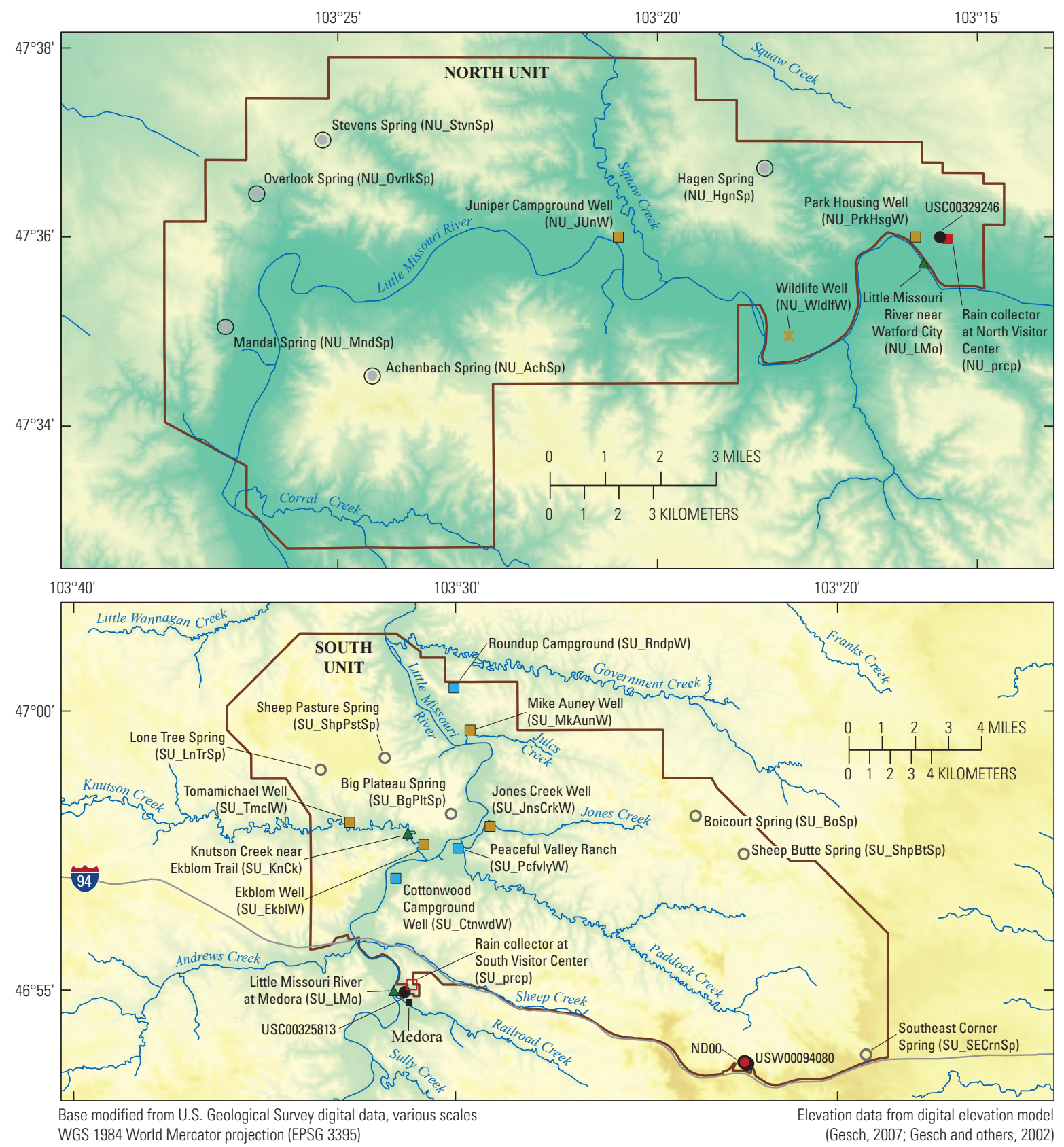

Horizontal coordinate information referenced to North American Datum of 1983 (NAD 83)

\section{EXPLANATION}

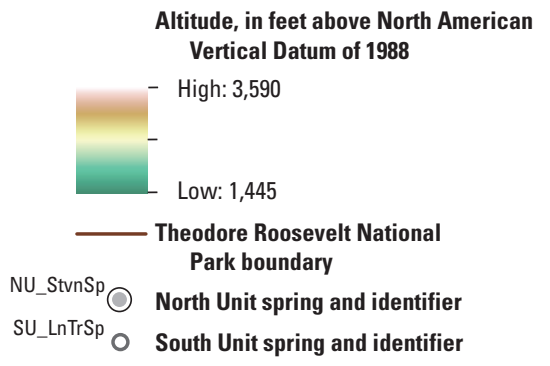

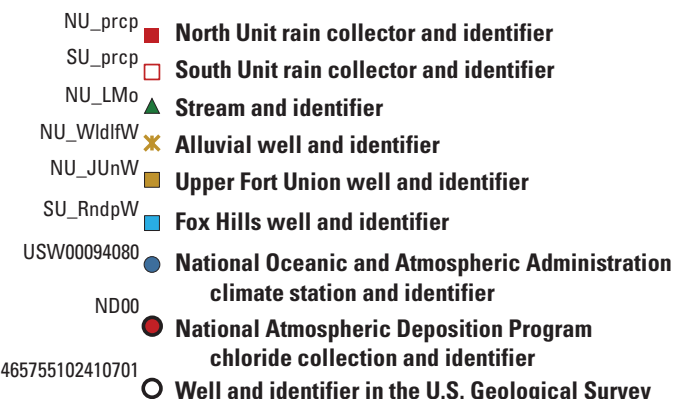

O Well and identifier in the U.S. Geological Survey

National Water Information System database (see inset)

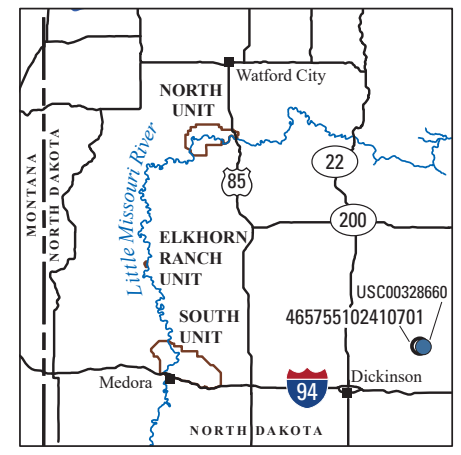

Figure 4. Springs, streams, wells, and rain collectors sampled in Theodore Roosevelt National Park. The map also shows the National Oceanic and Atmospheric Administration climate stations, National Atmospheric Deposition Program rain collectors, and a well in the U.S. Geological Survey National Water Information System (U.S. Geological Survey, 2020). 
Table 1. Summary of site information, including site number, site name, short name, location, elevation, elevation accuracy, depth to well bottom, and sample category, for water samples collected in Theodore Roosevelt National Park, 2018.

[USGS, U.S. Geological Survey; NAD 83, North American Datum of 1983; NAVD 88, North American Vertical Datum of 1988; ft, foot; bls, below land surface; NU, North Unit; SU, South Unit; nr, near; ND, North Dakota; Cmpgrd, campground; S, South; SE, Southeast]

\begin{tabular}{|c|c|c|c|c|c|c|c|c|}
\hline USGS site number1 & $\begin{array}{c}\text { USGS site name } 1 \\
\text { (when provided, name includes range- } \\
\text { township-section-quarter sections) }\end{array}$ & Short name & $\begin{array}{l}\text { Latitude } \\
\text { (NAD 83) }\end{array}$ & $\begin{array}{l}\text { Longitude } \\
\text { (NAD 83) }\end{array}$ & $\begin{array}{c}\text { Elevation } \\
\text { (ft, NAVD 88) }\end{array}$ & $\begin{array}{l}\text { Elevation } \\
\text { accuracy } \\
\quad(\mathrm{ft})\end{array}$ & $\begin{array}{l}\text { Well bottom } \\
\text { elevation } \\
\text { (ft bls) }\end{array}$ & Site type \\
\hline \multicolumn{9}{|c|}{ North Unit rain collector } \\
\hline 473600103153601 & Rain collector at North Visitor Center & NU_prep & 47.60001 & -103.26009 & 2,006 & 1.6 & -- & Rain collector \\
\hline \multicolumn{9}{|c|}{ South Unit rain collector } \\
\hline 465500103313501 & Rain collector at South Visitor Center & SU_prep & 46.91659 & -103.52643 & 2,262 & 4.3 & -- & Rain collector \\
\hline \multicolumn{9}{|c|}{ North Unit river } \\
\hline 06337000 & Little Missouri River nr Watford City, ND & NU_LMo & 47.59544 & -103.26337 & $1,930.77$ & 0.1 & -- & Stream \\
\hline \multicolumn{9}{|c|}{ South Unit river } \\
\hline 06336000 & Little Missouri River at Medora, ND & SU_LMo & 46.91807 & -103.53034 & $2,248.4$ & 0.1 & -- & Stream \\
\hline 465749103312401 & Knutson Creek Near Ekblom Trail & SU_KnCk & 46.96355 & -103.52335 & 2,260 & 4.3 & -- & Stream \\
\hline \multicolumn{9}{|c|}{ North Unit alluvium well } \\
\hline 473458103175501 & 147-099-04AC (NU Wildlife Well) & NU_WldlfW & 47.58281 & -103.29955 & 1,960 & 10.0 & 1,920 & Well \\
\hline \multicolumn{9}{|c|}{ Upper Fort Union aquifer wells } \\
\hline 473547103200901 & 148-099-31AC (NU Juniper Cmpgrd Well) & NU_JunW & 47.60002 & -103.34341 & 2,029 & 1.6 & 1,599 & Well \\
\hline 473601103155801 & 148-099-35BBCB (Park Housing Well) & NU_PrkHsgW & 47.60015 & -103.26624 & 1,980 & 1.6 & 1,605 & Well \\
\hline 465932103300001 & 141-101-32 (S Unit Mike Auney Well) & SU_MkAunW & 46.99224 & -103.50009 & 2,244 & 4.3 & 1,894 & Well \\
\hline 465755103292201 & 140-102-01DCAA (S Unit Jones Creek Well) & SU_JnsCrkW & 46.96539 & -103.48936 & 2,253 & 4.3 & 1,810 & Well \\
\hline 465756103330201 & 140-102-04DA (S Unit Tomamichael Well) & SU_TmclW & 46.96561 & -103.55056 & 2,314 & 4.3 & 1,674 & Well \\
\hline 465744103310601 & 140-102-2CDCD (Ekblom Well) & SU_EkblW & 46.96221 & -103.51821 & 2,273 & 4.3 & 2,273 & Well \\
\hline \multicolumn{9}{|c|}{ Fox Hills-lower Hell Creek aquifer wells } \\
\hline 470024103301601 & 141-101-29ABD (Roundup Campground) & SU_RndpW & 47.00663 & -103.50453 & 2,391 & 4.3 & 1,066 & Well \\
\hline 465700103314801 & 140-102-10DDBB (S Unit Campground Well) & SU_CtnwdW & 46.95012 & -103.53013 & 2,254 & 4.3 & 869 & Well \\
\hline 465721103300301 & $\begin{array}{l}\text { 140-102-12BC (S Unit Peaceful Valley Ranch } \\
\text { Well) }\end{array}$ & SU_PcfvlyW & 46.95896 & -103.50309 & 2,244 & 4.3 & 1,064 & Well \\
\hline \multicolumn{9}{|c|}{ North Unit springs } \\
\hline 473432103242801 & Achenbach Spring & NU_AchSp & 47.57551 & -103.40767 & 2,495 & 1.6 & -- & Spring \\
\hline 473644103181901 & Hagen Spring & NU_HgnSp & 47.61213 & -103.30540 & 2,248 & 1.6 & -- & Spring \\
\hline 473509103265101 & 147-100-05 (Mandal Spring) & NU_MndSp & 47.58398 & -103.44637 & 2,017 & 1.6 & -- & Spring \\
\hline
\end{tabular}


Table 1. Summary of site information, including site number, site name, short name, location, elevation, elevation accuracy, depth to well bottom, and sample category, for water samples collected in Theodore Roosevelt National Park, 2018.-Continued

[USGS, U.S. Geological Survey; NAD 83, North American Datum of 1983; NAVD 88, North American Vertical Datum of 1988; ft, foot; bls, below land surface; NU, North Unit; SU, South Unit; nr, near; ND, North Dakota; Cmpgrd, campground; S, South; SE, Southeast]

\begin{tabular}{|c|c|c|c|c|c|c|c|c|}
\hline USGS site number1 & $\begin{array}{l}\text { USGS site name }{ }^{1} \\
\text { (when provided, name includes range- } \\
\text { township-section-quarter sections) }\end{array}$ & Short name & $\begin{array}{l}\text { Latitude } \\
\text { (NAD 83) }\end{array}$ & $\begin{array}{l}\text { Longitude } \\
\text { (NAD 83) }\end{array}$ & $\begin{array}{c}\text { Elevation } \\
\text { (ft, NAVD 88) }\end{array}$ & $\begin{array}{l}\text { Elevation } \\
\text { accuracy } \\
\quad(\mathrm{ft})\end{array}$ & $\begin{array}{l}\text { Well bottom } \\
\text { elevation } \\
\text { (ft bls) }\end{array}$ & Site type \\
\hline \multicolumn{9}{|c|}{ North Unit springs-Continued } \\
\hline 473627103261601 & Overlook Spring & NU_OvrlkSp & 47.60762 & -103.43780 & 2,085 & 1.6 & -- & Spring \\
\hline 473701103251401 & Stevens Spring & NU_StvnSp & 47.61703 & -103.42067 & 2,360 & 1.6 & -- & Spring \\
\hline \multicolumn{9}{|c|}{ South Unit springs } \\
\hline 465807103235601 & Boicourt Spring & SU_BoSp & 46.96860 & -103.39886 & 2,630 & 4.3 & -- & Spring \\
\hline 465809103302201 & Big Plateau Spring & SU_BgPltSp & 46.96918 & -103.50625 & 2,438 & 4.3 & -- & Spring \\
\hline 465856103334401 & Lone Tree Spring & SU_LnTrSp & 46.98222 & -103.56234 & 2,596 & 4.3 & -- & Spring \\
\hline 465726103224301 & Sheep Butte Spring & SU_ShpBtSp & 46.95716 & -103.37863 & 2,634 & 4.3 & -- & Spring \\
\hline 465909103320401 & Sheep Pasture Spring & SU_ShpPstSp & 46.98588 & -103.53446 & 2,598 & 4.3 & -- & Spring \\
\hline 465350103192901 & SE Corner Spring & SU_SECrnSp & 46.89724 & -103.32480 & 2,709 & 4.3 & -- & Spring \\
\hline
\end{tabular}

1U.S. Geological Survey (2020). 
Chloride samples were analyzed by the USGS National Water Quality Laboratory in Lakewood, Colorado, using methods described by Fishman and Friedman (1989), Fishman (1993), and Garbarino and others (2006).

Samples were not collected at dry spring sites or at springs with discharge rates less than a slow drip (20-30 minutes to fill a $60-\mathrm{mL}$ bottle). Physical properties and chloride were not collected for precipitation samples due to rain collectors not collecting the water volume required for chloride sampling. Laboratory analysis results were stored in the USGS National Water Information System database (U.S. Geological Survey, 2020) and can be accessed using the USGS site numbers provided in table 1 .

Seven stable isotope replicate samples and six chloride replicate samples were collected for quality control. Replicates were collected within 10 minutes of the primary sample using the same collection procedures (table 2). Analysis of replicate samples alongside primary samples provide information regarding reproducibility and variability within samples and could indicate variations in field sampling techniques or laboratory processing and analysis. Variability between replicate and primary samples commonly is calculated by the relative percent difference (RPD; Sando and others, 2006; Long and others, 2012), defined as the absolute difference in concentration between the replicate and primary sample values, divided by the mean concentration of the primary and replicate sample values, and expressed as a percentage. The RPD of chloride samples ranged from 0.04 percent (Peaceful Valley Ranch Well) to 4.58 percent (Overlook Spring) with a mean of 1.42 percent (table 2). The RPD of $\delta 18 \mathrm{O}$ samples ranged from 0.12 percent (Overlook Spring) to 1.28 percent (Ekblom Well) with a mean of 0.59 percent. The RPD of $\delta^{2} \mathrm{H}$ samples ranged from 0.12 percent (Lone Tree Spring) to 0.44 percent (Achenbach Spring) with a mean of 0.29 percent. Generally, an RPD of 20 percent or less is considered acceptable for sample concentrations not near the limit of laboratory detectability (Putnam and others, 2008; Taylor, 1987).

\section{Stable Isotopes}

Hydrogeological studies commonly use stable isotopes of abundant elements that occur naturally, such as hydrogen, carbon, or oxygen, to estimate water provenance, age, recharge processes, and groundwater flow paths. In particular, stable isotopes of hydrogen (protium, ${ }^{1} \mathrm{H}$; deuterium, ${ }^{2} \mathrm{H}$; and tritium, ${ }^{3} \mathrm{H}$ ) and oxygen (oxygen- $16,{ }^{16} \mathrm{O}$; oxygen-17, ${ }^{17} \mathrm{O}$; and oxygen-18, ${ }^{18} \mathrm{O}$ ) are used as flow path tracers because they are found naturally in groundwater, and meteoric weather processes can modify their composition (Clark and Fritz, 1997). Stable isotope analysis of a water sample compares ratios of heavier to lighter isotopes to a standard isotope ratio of known composition (Clark and Fritz, 1997). The result is reported in delta $(\delta)$ notation in parts per thousand $(\%)$ calculated using equation 1 (Kendall and Caldwell, 1998):

$$
\delta=\left(\left[R_{x} \div R_{s}\right]-1\right) \times 1,000
$$

where

$R_{x}$ and $R_{s} \quad$ are the ratios of the sample and standard, respectively.

A positive value of $\delta$ indicates the sampled isotope ratio is higher than the standard, and a negative value of $\delta$ indicates the sampled ratio is lower than the standard (Kendall and Caldwell, 1998).

Stable isotope ratios of oxygen $(18 \mathrm{O} / 16 \mathrm{O})$ and hydrogen $\left({ }^{2} \mathrm{H} / 1 \mathrm{H}\right)$ were measured for water samples collected at springs, streams, wells, and rain collectors from May to September 2018 for this study. Stable isotope data were converted to $\delta$ notation using equation 1 and the Vienna Standard Mean Ocean Water and Standard Light Antarctic Precipitation standards (Révész and Coplen, 2008a, 2008b). The notations $\delta^{18} \mathrm{O}$ and $\delta^{2} \mathrm{H}$ are used in this report to describe the ratios of heavy to light isotopes of oxygen and hydrogen, respectively.

The $\delta^{18} \mathrm{O}$ and $\delta^{2} \mathrm{H}$ data from this study were plotted using a method described by Muir and Coplen (1981). Stable isotope samples generally are plotted with $\delta^{18} \mathrm{O}$ values on the $\mathrm{x}$-axis and $\delta^{2} \mathrm{H}$ values on the $\mathrm{y}$-axis. The global meteoric water line (GMWL) from Craig (1961) was plotted with the sample data to compare the stable isotopic composition of samples to the global stable isotopic composition of precipitation. Stable isotope ratios of local precipitation samples deviated from the GMWL and were plotted as the local meteoric water line (LMWL). Linear regression was used to determine a LMWL by relating $\delta^{2} \mathrm{H}$ to $\delta^{18} \mathrm{O}$ for precipitation samples from the North and South Units of the park. Stable isotope samples from springs, streams, wells, and rain collectors were plotted separately for May, July, and September 2018 in stable isotope plots. Rain collector samples were plotted similarly on stable isotope plots, except precipitation from June was included with July samples, and precipitation samples from August were included with September samples to match the site sampling schedule (May, July, September). No samples were enriched relative to the standards used to calculate stable isotopes ratios - indicated by all samples plotting below the origin on stable isotope plots; however, some samples plotted closer to the origin than other samples. Samples plotting closer to the origin in stable isotope plots are heavier (more enriched in heavy isotopes) than samples with more negative $\delta^{18} \mathrm{O}$ and $\delta^{2} \mathrm{H}$ values that plot further below the origin (fig. 5).

Ocean waters are considered to have heavy stable isotope compositions and, as precipitation that originates from ocean evaporation moves inland, become lighter in isotopes as the heavier isotopes preferentially fall to the surface during rains (fig. 5; U.S. Geological Survey, 2004). Generally, summer rains are heavier (more positive) than winter rains (more negative; fig. 5). Similarly, precipitation from cooler, high latitude, high altitude, and inland sources is lighter than precipitation from warmer, low latitude, low altitude, coastal areas (fig. 5; Sustainability of Semi-Arid Hydrology and Riparian Areas, 2020). Shallow groundwater stable isotope values are similar to precipitation values, but evaporation, 
Table 2. Primary and replicate sample data for select sites in the North and South Units of Theodore Roosevelt National Park.

[Sample dates are given in month, day, and year ( $\mathrm{mm} / \mathrm{dd} / \mathrm{yyyy}$ ). Sample times are given in hours and minutes (hh:mm, military). The relative percent difference (RPD) was calculated for chloride and stable isotope ratios of oxygen $\left(\delta^{18} \mathrm{O} / \delta^{16} \mathrm{O}\right)$ and hydrogen $\left(\delta^{2} \mathrm{H} / \delta^{1} \mathrm{H}\right)$ to determine the expected variance among samples. USGS, U.S. Geological Survey; mg/L, milligram per liter; \%, percent; S, South; SU, South Unit; NU, North Unit; --, not measured]

\begin{tabular}{|c|c|c|c|c|c|c|c|c|c|c|}
\hline USGS site number ${ }^{1}$ & $\begin{array}{l}\text { USGS site name }{ }^{1} \\
\text { (when provided, name includes } \\
\text { range-township-section-quarter } \\
\text { sections) }\end{array}$ & Short name & Sample date & $\begin{array}{l}\text { Sample } \\
\text { time }\end{array}$ & $\begin{array}{l}\text { Chloride, } \\
\text { filtered } \\
\text { (mg/L) }\end{array}$ & $\begin{array}{l}\text { RPD for } \\
\text { chloride } \\
\quad(\%)\end{array}$ & $\begin{array}{c}\delta^{180} / \delta^{160}, \\
\text { unfiltered, } \\
\text { per mil }\end{array}$ & $\begin{array}{c}\text { RPD for } \\
\delta^{180 / \delta^{160}} \\
(\%)\end{array}$ & $\begin{array}{c}\delta^{2} \mathrm{H} / \delta^{1} \mathrm{H}, \\
\text { unfiltered, } \\
\text { per mil }\end{array}$ & $\begin{array}{l}\text { RPD for } \\
\delta^{2} \mathrm{H} / \delta^{1} \mathrm{H} \\
(\%)\end{array}$ \\
\hline 465721103300301 & $\begin{array}{l}\text { 140-102-12BC (S UNIT } \\
\text { PEACEFUL VALLEY } \\
\text { RANCH WELL) }\end{array}$ & SU_PcfvlyW & $07 / 11 / 2018$ & $\begin{array}{l}09: 55 \\
10: 00\end{array}$ & $\begin{array}{l}52.50 \\
52.48\end{array}$ & 0.04 & $\begin{array}{l}-140.00 \\
-139.50\end{array}$ & 0.36 & $\begin{array}{l}-18.19 \\
-18.13\end{array}$ & 0.33 \\
\hline 473432103242801 & Achenbach Spring & NU_AchSp & $07 / 09 / 2018$ & $\begin{array}{l}13: 32 \\
13: 40\end{array}$ & $\begin{array}{l}2.380 \\
2.373\end{array}$ & 0.29 & $\begin{array}{l}-122.00 \\
-121.60\end{array}$ & 0.33 & $\begin{array}{l}-15.97 \\
-16.04\end{array}$ & 0.44 \\
\hline 473627103261601 & Overlook Spring & NU_OvrlkSp & $05 / 22 / 2018$ & $\begin{array}{l}12: 00 \\
12: 10\end{array}$ & $\begin{array}{l}5.340 \\
5.101\end{array}$ & 4.58 & $\begin{array}{l}-16.200 \\
-16.180\end{array}$ & 0.12 & $\begin{array}{l}-17.07 \\
-17.10\end{array}$ & 0.18 \\
\hline 473701103251401 & Stevens Spring & NU_StvnSp & $09 / 21 / 2018$ & $\begin{array}{l}09: 50 \\
10: 00\end{array}$ & $\begin{array}{l}9.030 \\
8.906\end{array}$ & 1.38 & $\begin{array}{r}-150.75 \\
-149.98\end{array}$ & 0.51 & $\begin{array}{l}-19.56 \\
-19.51\end{array}$ & 0.26 \\
\hline 465500103313501 & $\begin{array}{l}\text { Rain collector at South Visitor } \\
\text { Center }\end{array}$ & SU_prep_10May & 05/10/2018 & $\begin{array}{l}19: 58 \\
19: 59\end{array}$ & $\begin{array}{l}-- \\
--\end{array}$ & -- & $\begin{array}{l}-92.900 \\
-94.030\end{array}$ & 1.21 & $\begin{array}{l}-11.57 \\
-11.62\end{array}$ & 0.43 \\
\hline 465856103334401 & Lone Tree Spring & SU_LnTrSp & $05 / 21 / 2018$ & $\begin{array}{l}14: 45 \\
14: 50\end{array}$ & $\begin{array}{l}2.400 \\
2.442\end{array}$ & 1.73 & $\begin{array}{l}-125.40 \\
-124.98\end{array}$ & 0.34 & $\begin{array}{l}-16.20 \\
-16.18\end{array}$ & 0.12 \\
\hline 465744103310601 & 140-102-2CDCD (Ekblom Well) & SU_EkblW & 09/20/2018 & $\begin{array}{l}12: 37 \\
12: 47 \\
\text { Mean }\end{array}$ & $\begin{array}{c}8.380 \\
8.420 \\
--\end{array}$ & $\begin{array}{l}0.48 \\
1.42\end{array}$ & $\begin{array}{c}-154.51 \\
-152.54 \\
--\end{array}$ & $\begin{array}{l}1.28 \\
0.59\end{array}$ & $\begin{array}{l}-20.09 \\
-20.14 \\
--\end{array}$ & 0.29 \\
\hline
\end{tabular}

1U.S. Geological Survey (2020). 
transpiration, and fractionation may alter the stable isotope ratios as the water moves downward towards the saturation zone (U.S. Geological Survey, 2004). Additionally, evaporative loss from rivers, reservoirs, and lakes changes the isotopic composition of water, causing it to become heavier (fig. 5; Sustainability of Semi-Arid Hydrology and Riparian Areas, 2020).

\section{Chloride Mass-Balance Analysis}

The CMB method estimates recharge rates to aquifers in arid and semiarid environments based on the chloride concentration of a water sample and the rate of atmospheric chloride deposition (McCoy and Blanchard, 2008). The chloride ion

$\left(\mathrm{Cl}^{-}\right)$is a useful environmental tracer in groundwater because it is not a prominent reagent in geochemical processes, and it is conservative, meaning that chloride remains in solution and becomes more concentrated during evaporation and transpiration (Brooks and Mason, 2005). The CMB method assumes the primary source of chloride in groundwater is from precipitation; therefore, if the volume of precipitation, the concentration of chloride in the precipitation, and the concentration of chloride in the groundwater are known, the volume of water recharging the aquifer can be calculated using equation 2 (Wood and Sanford, 1995; Brooks and Mason, 2005):

$$
q=\left(P \times C l_{p}\right) \div C l_{g w}
$$

where

$$
\begin{aligned}
q & \text { is the recharge volume, in inches; } \\
P & \text { is precipitation, in inches; } \\
C l_{p} & \text { is the effective chloride concentration in the } \\
& \text { precipitation, in milligrams per liter; and } \\
C l_{g w} & \text { is the chloride concentration in the } \\
& \text { groundwater, in milligrams per liter. }
\end{aligned}
$$

Effective chloride concentrations include both wet and dry deposition rates, but dry deposition data are not recorded regionally; therefore, $\mathrm{CMB}$ calculations often assume that dry and wet deposition are equal (Gates and others, 2008). Precipitation that infiltrates quickly results in low chloride concentrations in groundwater; conversely, precipitation that infiltrates slowly results in higher chloride concentrations (Healy, 2010).

Wood (1999) and Brooks and Mason (2005) list the following assumptions for the CMB method: (1) the only source of chloride in groundwater is from direct precipitation on aquifer materials; (2) chloride concentration in groundwater is affected by evapotranspiration within the unsaturated zone, not from recycling, dissolution of minerals containing chloride, or inflow from adjacent aquifers; (3) chloride is conservative in the groundwater system; and (4) the mass flux of chloride in a system does not change. In this study, the first three assumptions are valid for groundwater from springs sourced from unconfined or alluvial aquifers above low permeability confining units. Spring flow sourced from groundwater that originates from or mixes with bedrock aquifers composed of

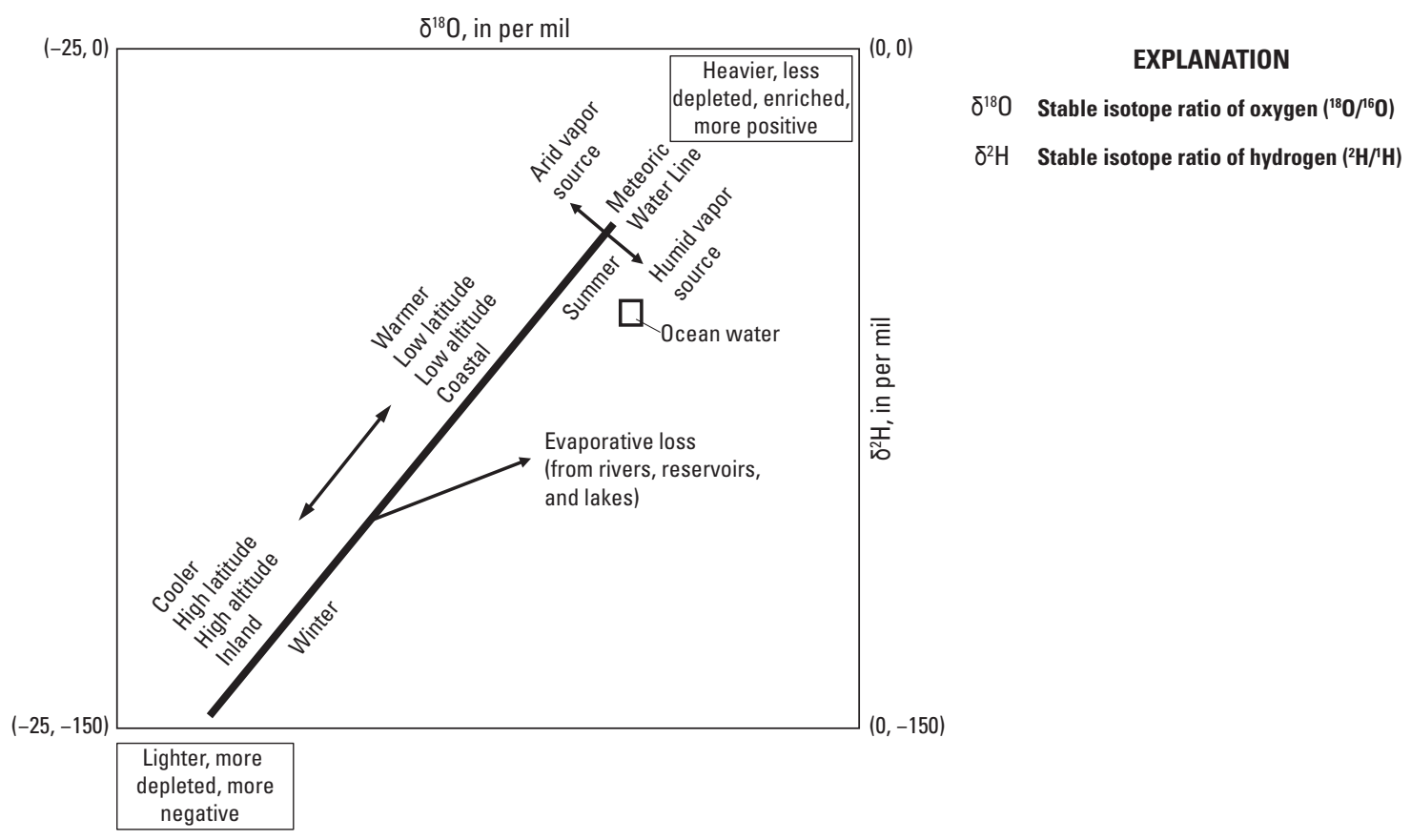

Figure 5. The effects of hydrologic processes on the oxygen and hydrogen isotopic composition of water. Modified from Sustainability of Semi-Arid Hydrology and Riparian Areas (2020). 
marine sedimentary rocks would not satisfy these assumptions. All springs in the North and South Units of the park are in either the Sentinel Butte and Bullion Creek Formations of the Fort Union Group (fig. 2), both of which were deposited from terrestrial sources (Murphy and others, 2009). Assumption four is valid for the study area because, according to data from NADP (2020), the long-term mean chloride concentration in rainfall is consistent, and stream water generally does not influence regional chloride concentrations in semiarid climates.

Precipitation volume for the study was calculated from NOAA climate data from three stations near the North and South Units of the park from January 1, 2018, through December 31, 2018 (fig. 4). The Watford City 14S, N. Dak., climate station (USC00329246) is in the North Unit. The Medora (USC00325813) and Medora 7E (USC00094080), N. Dak., climate stations are in the South Unit near Medora and about $10 \mathrm{mi}$ east of Medora, respectively. The value of the $P$ variable in equation 2 was calculated by summing precipitation for 12 days before the sampling date at each site using precipitation data from the nearest NOAA climate station. The 12-day period was based on the lag time observed between cumulative precipitation in 2018 from NOAA climate station Taylor 7 NNW, N. Dak. (USC00328660; fig. 4) and 2018 water levels from a well completed in an unconfined part of the upper Fort Union aquifer near Dickinson, N. Dak. (USGS site 465755102410701; figs. 4, 6). USGS site 465755102410701 was selected because it was the only well completed in an unconfined part of the upper Fort Union aquifer with daily water-level data in the USGS National Water Information System and North Dakota State Water Commission (North Dakota State Water Commission, 2015) databases.

Chloride concentration data from the NADP from January 1 through December 31, 2018, were used to determine the mean chloride concentration of rainwater for $\mathrm{Cl}_{p}$ in equation 2. The only active NADP site in the study area in 2018 was in the South Unit of the park about 10 mi east of Medora

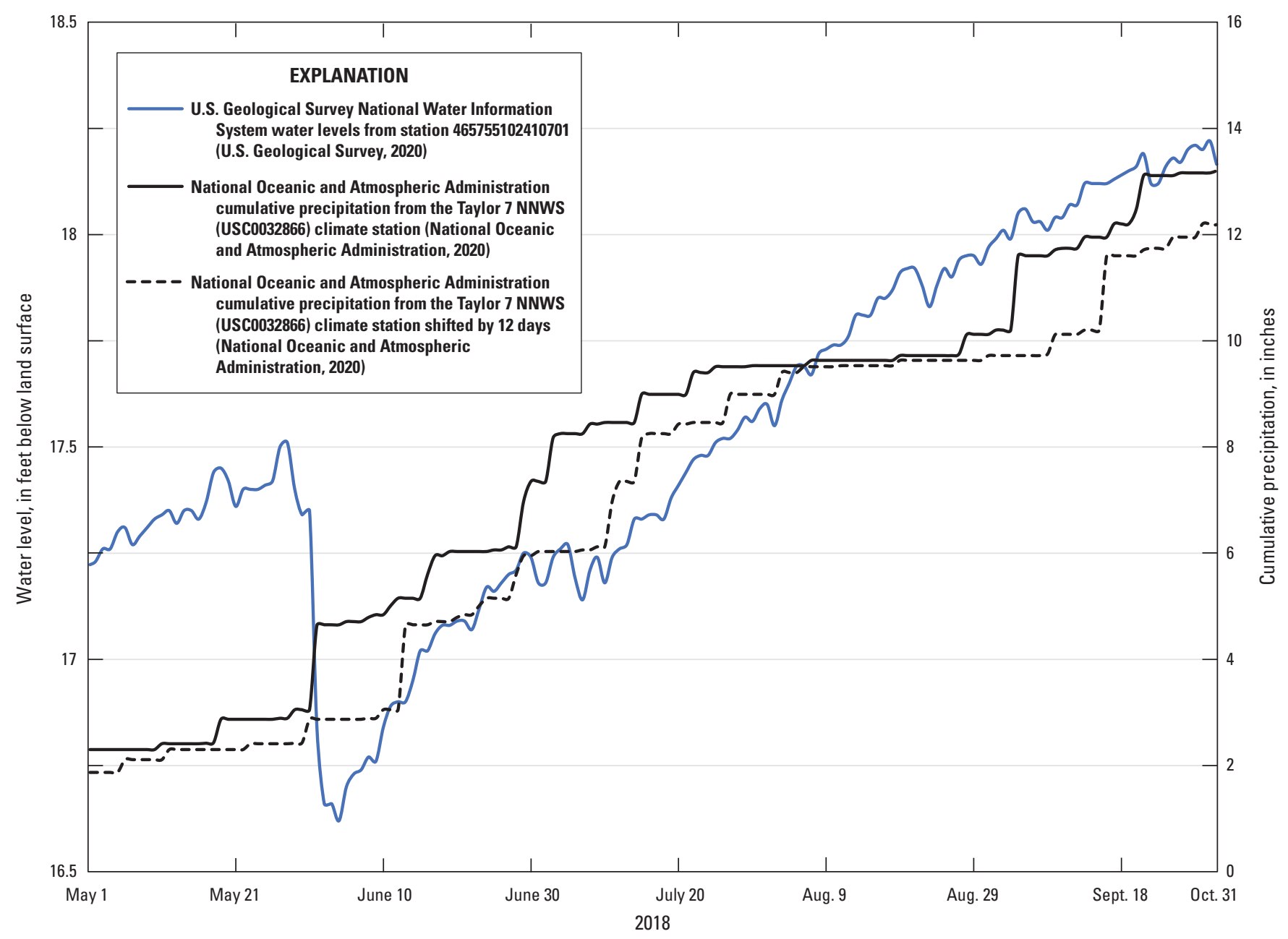

Figure 6. A 12-day lag time from May 1 to 0 ctober 1, 2018, between the cumulative precipitation curve for the National 0ceanic and Atmospheric Administration Taylor 7 NNWS (USC0032866) climate station and water levels in a well completed in an unconfined part of the upper Fort Union near Dickinson, North Dakota. 
(ND00; fig. 4). The chloride concentration data from this site were used in calculations for North and South Unit springs. The value of $C l_{p}$ was calculated by dividing the total mass of chloride by the total volume of precipitation to determine a mean chloride concentration for the 12-day period before the water sampling date. The 12-day period was appropriate due to the small variability of chloride concentrations in precipitation events (Neal and Kirchner, 2000). The chloride concentration measured from each spring water sample was used for the $\mathrm{Cl}_{g w}$ variable in equation 2.

Equation 2 was used to calculate 12-day recharge rates for aquifers supplying each spring and for the alluvial aquifer well (Wildlife well). Additionally, 12-day percent recharge and annual recharge rates were estimated for each spring using 12-day recharge rates. Recharge rate estimates were computed using equation 2 with total precipitation and 12-day mean chloride concentration data determined from NADP (2020) data. The 12-day percent recharge estimates were calculated by dividing the 12-day recharge rate by the total amount of precipitation in the 12-day period before sampling. Annual recharge rates were estimated by converting the 12-day recharge rate to a daily rate (dividing by 12 days) and then multiplying by 365 days. The annual mean recharge from precipitation was calculated by taking the mean of the individual recharge rates calculated for multiple samples from each site.

\section{Principal Component Analysis}

PCA is a multivariate technique that tests for linear relations among variables in a dataset (Helsel and others, 2020). The PCA method is performed by linearly transforming the original dataset into new axes, called principal components, that are linear combinations of all the input variables. The principal components responsible for the most variance (principal components one and two) are used to plot multidimensional data in two dimensions so data patterns and groupings can be observed and interpreted (Long and Valder, 2011). Additional details and mathematical derivations of PCA are provided in Davis (2002). Python programming language (Rossum and Drake, 2011) was used to implement the PCA method.

The PCA method was performed on the physical property and chemical constituent data collected for this study. The physical property and chemical constituent data included water temperature, specific conductance, $\mathrm{pH}$, chloride, $\delta^{2} \mathrm{H}$, and $\delta^{18} \mathrm{O}$. Physical properties and chloride concentrations were not measured for precipitation samples and for two samples from Sheep Butte Spring (SU_ShpBtSp; table 2); therefore, those samples were excluded from PCA analysis because the method requires data types to have the same number of variables. Physical property and chemical constituent data were normalized, by setting the mean of each variable to zero, and standardized, by setting the standard deviation of each variable to one, before performing PCA to ensure that the distribution of the dataset was independent of measurement units (Davis, 2002).
Principal component biplots were created to visualize the results on principal component axes one and two. Biplots are PCA plots with vectors, called loading lines, that relate variance and correlation of the variables. Variance is represented by the magnitude of the vector, with larger vectors meaning larger variance, whereas correlation is represented by the direction of the vector, with opposite direction vectors meaning negative correlation (Jolliffe, 2002). Individual data points that plot close to loading lines have above-mean values for that loading line variable; conversely, data points that plot opposite of loading lines have lower than normal values for that loading line variable (Jolliffe, 2002).

\section{Cluster Analysis}

Cluster analysis is a method of assigning data points to groups, called clusters, based on similarities (Long and Valder, 2011). The cluster analysis method selected for this study was the $k$-means procedure because of its simplicity and frequent use in hydrological studies (Long and Valder, 2011; Masoud, 2014; Celestino and others, 2018). The $k$-means procedure involves iteratively finding the minimum Euclidean distance between a manually selected number of cluster centroids, $k$, and an observation, $n$ (Davis, 2002). Iterations continue until the location of each $k$ is optimized and every observation is assigned to a cluster.

In this study, the $k$-means procedure was used to determine clusters for the PCA results of water-chemistry data collected during this study. The purpose of using the $k$-means procedure was to statistically group sampling sites without introducing bias. The number of clusters for the $k$-means procedure was determined using scree plots (Jolliffe, 2002). Scree plots are constructed by plotting the number of cluster groups in numerical order (x-axis) against their respective sum of squared distances of samples to the nearest cluster centroid (y-axis). The optimal number of clusters from the $k$-means procedure can be determined by observing the "break point" in scree plots. The "break point" is the sharp change in slope (steep to nearly flat) of the scree plot curve that marks where increasing the number of clusters is no longer beneficial to the $k$-means procedure. After selecting the number of clusters, the $k$-means procedure was computed using 10 runs at 300 iterations per run (a total of 3,000 iterations) for data plotted in principal component axes one and two. The $k$-means procedure settings were chosen because the cluster results did not improve with increased runs and iterations. Python programming language (Rossum and Drake, 2011) was used to perform the $k$-means procedure.

\section{End Member Mixing Analysis}

EMMA can be used to determine the proportion of water in a mixed sample from one or more water sources, called end members. Long and others (2019) defined an end member as a water source with a distinct geochemical signature. The 
number of end members can be determined from the mixture, by the process of inverse analysis, or from independent data collected from potential sources, using forward analysis, such as groundwater wells, precipitation, and streams (Christophersen and Hooper, 1992). The PCA method can be applied to inverse analyses where the number and composition of end members are derived from mixed samples (Christophersen and Hooper, 1992). The PCA method also can be applied to forward analysis using a constrained least squares solution to determine the composition of known end members (Christophersen and others, 1990; Hooper and others, 1990). EMMA traditionally is used to identify and quantify sources of water responsible for streamflow at multiple scales and spanning a range of geographic, geologic, and climatic conditions (Frisbee and others, 2013); however, several studies have used EMMA to identify and quantify sources of water recharge to springs (Long and others, 2012, 2019; Frisbee and others, 2013; Valder and others, 2012; Zdon and others, 2018).

The EMMA for this study used forward analysis that incorporated data from two potential end members using stable isotope data. Forward analysis was used rather than inverse analysis because data from potential end members (groundwater and precipitation) were collected during this study, and Christophersen and Hooper (1992) determined that incorporating data from real sources improved EMMA results. The first step in EMMA is to perform PCA on the input data to verify the chosen number of end members and to project the PCA results into principal component axes one and two to examine if the chosen end members encapsulate the mixed samples (Christophersen and Hooper, 1992). However, rain collector samples were not included in the PCA results because they were only sampled for stable isotope data. PCA can be performed on data only if they all possess the same number of variables (in this case, physical properties and chemical constituents). The PCA results for this study, however, showed that stable isotope data $\left(\delta^{18} \mathrm{O}\right.$ and $\left.\delta^{2} \mathrm{H}\right)$ explained most of the variation in the water-chemistry dataset; therefore, the stable isotope data were used instead of PCA results to perform EMMA on a two-end member model.

End members were determined using stable isotope data from May to September 2018. The stable isotope data showed two distinct end members that could be used to determine percent contributions for each spring. One end member was water from the upper Fort Union aquifer. The upper Fort Union aquifer was selected as an end member because the $\delta^{18} \mathrm{O}$ and $\delta^{2} \mathrm{H}$ values were more depleted than spring samples, and parts of the geologic formations that contain the upper Fort Union aquifer are exposed at the land surface in the park where springs and seeps have been mapped (Biek and Gonzalez, 2001) and observed to flow from aquifer materials. Although the Fox Hills-lower Hell Creek aquifer had similar stable isotope values as the upper Fort Union aquifer, and was more depleted than spring samples, it was not considered an end member because the aquifer commonly is greater than $1,000 \mathrm{ft}$ below land surface (Croft, 1985) and is hydrologically disconnected from springs and seeps in the park. The second end member was a composite of rain collector samples from the North and South Units of the park and was selected because the isotopes from precipitation were more enriched than the samples from springs. Spring samples were considered a mixture of the end members by reason that the $\delta^{18} \mathrm{O}$ and $\delta^{2} \mathrm{H}$ values were between upper Fort Union groundwater and precipitation. Stream samples were not used as an end member because the sampled streams were at lower altitudes than the springs and likely not sources of water to the springs (fig. 4).

The EMMA estimated the percent contributions of upper Fort Union aquifer groundwater and precipitation. Stable isotope plots were constructed using $\delta^{18} \mathrm{O}$ and $\delta^{2} \mathrm{H}$ values to show the distribution of spring samples between upper Fort Union aquifer and rain collector samples. The stable isotope plots showed that all spring, upper Fort Union aquifer, and rain collector samples plotted linearly with minor deviations. The percent contribution calculations were simplified by assuming that all samples fit linearly and the plotted distances between an end member and a spring were representative of the proportions of the end members in the sample. The percent contribution of an end member was calculated by dividing the Euclidean distance between the end member and the spring by the total distance between the two end members.

\section{Water-Chemistry and Multivariate Statistical Analyses}

Water-chemistry and multivariate statistical analysis results are discussed in this section. Laboratory and fieldmeasured results of physical properties, chemical constituents, and stable isotopes from samples collected during this study are listed in table 3 . The following describes analysis of stable isotope results, $\mathrm{CMB}$ calculations, PCA, cluster analysis, and EMMA results for data collected during the study. Principal component and clustering analyses of water-chemistry data from a National Park Service study in the 1980s (National Park Service, 1997) are included in appendix 1.

\section{Comparisons to Meteoric Conditions and Sampling Site Evaluations using Stable Isotopes}

Stable isotope data from sample sites in Theodore Roosevelt National Park provided information on the aquifers supplying springs in the park. The following sections list ranges of stable isotope compositions by location and site, describe comparisons of the stable isotope data collected during this study in May-September 2018 to global annual mean meteoric waters, describe analyses of stable isotope results from samples of springs and the alluvial aquifer well, describe analyses of the results of groundwater stable isotope data from 
[Sample dates are given in month, day, and year (mm/dd/yyyy). USGS, U.S. Geological Survey; ${ }^{\circ} \mathrm{C}$, degree Celsius; $\mu \mathrm{S} / \mathrm{cm}$ at $25^{\circ} \mathrm{C}$, microsiemens per centimeter at 25 degrees Celsius; mg/L, milligram per liter; NU, North Unit; --, not measured; SU, South Unit; nr, near; ND, North Dakota; Cmpgrd, campground; S, South; SE, southeast]

\begin{tabular}{|c|c|c|c|c|c|c|c|c|c|}
\hline \multirow[b]{2}{*}{ USGS site number ${ }^{1}$} & \multirow[b]{2}{*}{ USGS site name ${ }^{1}$} & \multirow[b]{2}{*}{ Short name } & \multirow[b]{2}{*}{ Sample date } & \multicolumn{3}{|c|}{ Physical parameters } & \multicolumn{3}{|c|}{ Chemical constituents } \\
\hline & & & & $\begin{array}{c}\text { Water } \\
\text { temperature } \\
\left({ }^{\circ} \mathrm{C}\right)\end{array}$ & $\begin{array}{c}\text { Specific } \\
\text { conductance } \\
(\mu \mathrm{S} / \mathrm{cm} \text { at } \\
\left.25^{\circ} \mathrm{C}\right)\end{array}$ & $\begin{array}{c}\text { pH } \\
\text { (standard } \\
\text { units) }\end{array}$ & $\begin{array}{l}\text { Chloride, } \\
\text { filtered } \\
\text { (mg/L) }\end{array}$ & $\begin{array}{c}\delta 180 / \delta 160, \\
\text { unfiltered } \\
\text { (per mil) }\end{array}$ & $\begin{array}{c}\delta^{2} \mathrm{H} / \delta^{1} \mathrm{H}, \\
\text { unfiltered } \\
\text { (per mil) }\end{array}$ \\
\hline \multicolumn{10}{|c|}{ North Unit precipitation } \\
\hline \multirow[t]{6}{*}{473600103153601} & \multirow{6}{*}{$\begin{array}{l}\text { Rain collector at North } \\
\text { Visitor Center }\end{array}$} & NU_prcp_5May & $05 / 16 / 2018$ & -- & -- & -- & -- & -8.840 & -68.66 \\
\hline & & NU_prcp_17Jun & 06/17/2018 & -- & -- & -- & -- & -11.86 & -89.20 \\
\hline & & NU_prcp_3Jul & 07/03/2018 & -- & -- & -- & -- & -10.87 & -87.00 \\
\hline & & NU_prcp_22Jul & $07 / 22 / 2018$ & -- & -- & -- & -- & -8.970 & -67.10 \\
\hline & & NU_prcp_6Aug & 08/06/2018 & -- & -- & -- & -- & -13.09 & -116.0 \\
\hline & & NU_prcp_9Sep & 09/09/2018 & -- & -- & -- & -- & -6.690 & -58.10 \\
\hline \multicolumn{10}{|c|}{ South Unit precipitation } \\
\hline \multirow[t]{4}{*}{465500103313501} & \multirow{4}{*}{$\begin{array}{l}\text { Rain collector at South } \\
\text { Visitor Center }\end{array}$} & SU_prcp_10May & $05 / 10 / 2018$ & -- & -- & -- & -- & -11.57 & -92.90 \\
\hline & & SU_prcp_18May & 05/18/2018 & -- & -- & -- & -- & -9.570 & -62.79 \\
\hline & & SU_prcp_3Jul & $07 / 03 / 2018$ & -- & -- & -- & -- & -10.65 & -79.90 \\
\hline & & SU_prcp_28Aug & 08/28/2018 & -- & -- & -- & -- & -14.22 & -104.0 \\
\hline \multicolumn{10}{|c|}{ North Unit river } \\
\hline \multirow[t]{3}{*}{06337000} & \multirow{3}{*}{$\begin{array}{l}\text { Little Missouri River nr } \\
\text { Waterford City, ND }\end{array}$} & NU_LMo & $05 / 22 / 2018$ & 18.6 & 1,540 & 8.4 & 7.49 & -14.11 & -113.0 \\
\hline & & & 07/09/2018 & 25.2 & 1,260 & 8.2 & 7.20 & -9.010 & -75.50 \\
\hline & & & 09/20/2018 & 10.3 & 1,960 & 8.3 & 12.1 & -10.95 & -96.90 \\
\hline \multicolumn{10}{|c|}{ South Unit river } \\
\hline \multirow[t]{3}{*}{06336000} & \multirow{3}{*}{$\begin{array}{l}\text { Little Missouri River at } \\
\text { Medora, ND }\end{array}$} & SU_LMo & $05 / 21 / 2018$ & 15.6 & 1,540 & 8.5 & 7.95 & -14.84 & -121.0 \\
\hline & & & $07 / 11 / 2018$ & 25.7 & 1,710 & 8.5 & 12.2 & -9.680 & -81.70 \\
\hline & & & 09/19/2018 & 15.6 & 2,230 & 8.6 & 12.3 & -8.910 & -88.40 \\
\hline \multirow[t]{3}{*}{465749103312401} & \multirow{3}{*}{$\begin{array}{l}\text { Knutson Creek Near } \\
\text { Ekblom Trail }\end{array}$} & SU_KnCk & $05 / 21 / 2018$ & 24.5 & 6,050 & 7.7 & 12.6 & -13.02 & -111.0 \\
\hline & & & 07/10/2018 & 25.2 & 3,860 & 8.5 & 7.71 & -8.730 & -78.00 \\
\hline & & & $09 / 20 / 2018$ & 10.5 & 2,790 & 8.7 & 8.70 & -11.31 & -90.90 \\
\hline \multicolumn{10}{|c|}{ North Unit alluvial aquifer well } \\
\hline \multirow[t]{3}{*}{473458103175501} & 147-099-04AC & NU_WldlfW & $05 / 22 / 2018$ & 8.80 & 3,520 & 7.7 & 8.24 & -16.90 & -129.0 \\
\hline & & & 07/09/2018 & 11.5 & 3,520 & 7.5 & 5.41 & -16.84 & -129.0 \\
\hline & & & 09/20/2018 & 13.3 & 3,390 & 7.9 & 5.34 & -16.60 & -128.0 \\
\hline
\end{tabular}


Table 3. Summary of water-chemistry results for samples collected from springs, streams, wells, and rain collectors in Theodore Roosevelt National Park, North Dakota.Continued

[Sample dates are given in month, day, and year (mm/dd/yyyy). USGS, U.S. Geological Survey; ${ }^{\circ} \mathrm{C}$, degree Celsius; $\mu \mathrm{S} / \mathrm{cm}$ at $25^{\circ} \mathrm{C}$, microsiemens per centimeter at 25 degrees Celsius; mg/L, milligram per liter; NU, North Unit; --, not measured; SU, South Unit; nr, near; ND, North Dakota; Cmpgrd, campground; S, South; SE, southeast]

\begin{tabular}{|c|c|c|c|c|c|c|c|c|c|}
\hline \multirow[b]{2}{*}{ USGS site number ${ }^{1}$} & \multirow[b]{2}{*}{ USGS site name ${ }^{1}$} & \multirow[b]{2}{*}{ Short name } & \multirow[b]{2}{*}{ Sample date } & \multicolumn{3}{|c|}{ Physical parameters } & \multicolumn{3}{|c|}{ Chemical constituents } \\
\hline & & & & $\begin{array}{c}\text { Water } \\
\text { temperature } \\
\left({ }^{\circ} \mathrm{C}\right)\end{array}$ & $\begin{array}{c}\text { Specific } \\
\text { conductance } \\
(\mu \mathrm{S} / \mathrm{cm} \text { at } \\
\left.25^{\circ} \mathrm{C}\right)\end{array}$ & $\begin{array}{c}\text { pH } \\
\text { (standard } \\
\text { units) }\end{array}$ & $\begin{array}{l}\text { Chloride, } \\
\text { filtered } \\
\text { (mg/L) }\end{array}$ & $\begin{array}{c}\delta 180 / \delta 160, \\
\text { unfiltered } \\
\text { (per mil) }\end{array}$ & $\begin{array}{c}\delta^{2} \mathrm{H} / \delta 1 \mathrm{H}, \\
\text { unfiltered } \\
\text { (per mil) }\end{array}$ \\
\hline \multicolumn{10}{|c|}{ Upper Fort Union aquifer wells } \\
\hline \multirow[t]{3}{*}{473547103200901} & \multirow{3}{*}{$\begin{array}{l}\text { 148-099-31AC (NU } \\
\text { Juniper Cmpgrd Well) }\end{array}$} & \multirow[t]{3}{*}{ NU_JunW } & $05 / 22 / 2018$ & 13.6 & 2,200 & 8.4 & 8.12 & -19.73 & -152.0 \\
\hline & & & 07/09/2018 & 13.3 & 2,350 & 8.1 & 8.05 & -19.82 & -152.0 \\
\hline & & & 09/20/2018 & 11.0 & 2,220 & 8.3 & 10.4 & -19.76 & -152.0 \\
\hline \multirow[t]{3}{*}{473601103155801} & \multirow{3}{*}{$\begin{array}{l}\text { 148-099-35BBCB (Park } \\
\text { Housing Well) }\end{array}$} & \multirow[t]{3}{*}{ NU_PrkHsgW } & $05 / 22 / 2018$ & 9.20 & 2,150 & 8.4 & 7.84 & -19.77 & -151.0 \\
\hline & & & 07/09/2018 & 21.8 & 2,400 & 8.3 & 55.5 & -19.70 & -151.0 \\
\hline & & & 09/20/2018 & 17.0 & 2,260 & 8.4 & 41.4 & -19.73 & -152.0 \\
\hline \multirow[t]{3}{*}{465932103300001} & \multirow{3}{*}{$\begin{array}{l}\text { 141-101-32 (S Unit Mike } \\
\text { Auney Well) }\end{array}$} & \multirow[t]{3}{*}{ SU_MkAunW } & $05 / 23 / 2018$ & 14.7 & 1,640 & 9.0 & 9.80 & -20.18 & -155.0 \\
\hline & & & 07/10/2018 & 12.1 & 1,620 & 8.8 & 10.2 & -20.16 & -155.0 \\
\hline & & & 09/20/2018 & 11.9 & 1,620 & 8.8 & 10.2 & -20.16 & -156.0 \\
\hline \multirow[t]{3}{*}{465755103292201} & \multirow{3}{*}{$\begin{array}{l}\text { 140-102-01DCAA (S } \\
\text { Unit Jones Creek Well) }\end{array}$} & \multirow[t]{3}{*}{ SU_JnsCrkW } & $05 / 21 / 2018$ & 10.0 & 1,800 & 9.4 & 10.0 & -20.23 & -155.0 \\
\hline & & & $07 / 11 / 2018$ & 11.3 & 1,840 & 9.1 & 9.90 & -20.27 & -155.0 \\
\hline & & & 09/19/2018 & 13.0 & 1,790 & 8.9 & 9.93 & -20.13 & -154.0 \\
\hline \multirow[t]{3}{*}{465756103330201} & \multirow{3}{*}{$\begin{array}{l}\text { 140-102-04DA (S Unit } \\
\text { Tomamichael Well) }\end{array}$} & \multirow[t]{3}{*}{ SU_TmclW } & $05 / 21 / 2018$ & 14.1 & 1,940 & 8.2 & 10.7 & -20.12 & -154.0 \\
\hline & & & 07/10/2018 & 15.8 & 1,960 & 8.8 & 10.9 & -20.12 & -155.0 \\
\hline & & & 09/20/2018 & 9.10 & 2,040 & 9.1 & 11.0 & -20.08 & -155.0 \\
\hline \multirow[t]{3}{*}{465744103310601} & \multirow{3}{*}{$\begin{array}{r}\text { 140-102-2CDCD } \\
\text { (Ekblom Well) }\end{array}$} & \multirow[t]{3}{*}{ SU_EkblW } & $05 / 21 / 2018$ & 13.0 & 1,780 & 8.5 & 8.03 & -20.16 & -154.0 \\
\hline & & & $07 / 10 / 2018$ & 13.8 & 1,910 & 9.5 & 8.35 & -20.22 & -154.0 \\
\hline & & & 09/20/2018 & 12.1 & 2,020 & 9.1 & 8.38 & -20.14 & -152.0 \\
\hline \multicolumn{10}{|c|}{ Fox Hills-lower Hell Creek aquifer wells } \\
\hline \multirow[t]{3}{*}{470024103301601} & \multirow{3}{*}{$\begin{array}{l}\text { 141-101-29ABD } \\
\text { (Roundup } \\
\text { Campground) }\end{array}$} & \multirow[t]{3}{*}{ SU_RndpW } & $05 / 21 / 2018$ & 11.1 & 1,750 & 8.8 & 51.5 & -18.26 & -141.0 \\
\hline & & & $07 / 11 / 2018$ & 19.2 & 1,850 & 8.5 & 53.3 & -18.32 & -140.0 \\
\hline & & & 09/19/2018 & 16.4 & 1,780 & 8.8 & 56.6 & -18.17 & -142.0 \\
\hline \multirow[t]{3}{*}{465700103314801} & & SU_CtnwdW & $05 / 21 / 2018$ & 11.6 & 1,720 & 8.9 & 105 & -18.01 & -141.0 \\
\hline & Unit Campground & & $07 / 11 / 2018$ & 17.5 & 1,800 & 8.5 & 96.1 & -18.02 & -139.0 \\
\hline & & & 09/19/2018 & 15.1 & 1,950 & 8.0 & 79.8 & -18.04 & -140.0 \\
\hline
\end{tabular}


Table 3. Summary of water-chemistry results for samples collected from springs, streams, wells, and rain collectors in Theodore Roosevelt National Park, North Dakota.Continued

[Sample dates are given in month, day, and year (mm/dd/yyyy). USGS, U.S. Geological Survey; ${ }^{\circ} \mathrm{C}$, degree Celsius; $\mu \mathrm{S} / \mathrm{cm}$ at $25^{\circ} \mathrm{C}$, microsiemens per centimeter at 25 degrees Celsius; mg/L, milligram per liter; NU, North Unit; --, not measured; SU, South Unit; nr, near; ND, North Dakota; Cmpgrd, campground; S, South; SE, southeast]

\begin{tabular}{|c|c|c|c|c|c|c|c|c|c|}
\hline \multirow[b]{2}{*}{ USGS site number ${ }^{1}$} & \multirow[b]{2}{*}{ USGS site name ${ }^{1}$} & \multirow[b]{2}{*}{ Short name } & \multirow[b]{2}{*}{ Sample date } & \multicolumn{3}{|c|}{ Physical parameters } & \multicolumn{3}{|c|}{ Chemical constituents } \\
\hline & & & & $\begin{array}{c}\text { Water } \\
\text { temperature } \\
\left({ }^{\circ} \mathrm{C}\right)\end{array}$ & $\begin{array}{c}\text { Specific } \\
\text { conductance } \\
(\mu \mathrm{S} / \mathrm{cm} \text { at } \\
\left.25^{\circ} \mathrm{C}\right)\end{array}$ & $\begin{array}{c}\text { pH } \\
\text { (standard } \\
\text { units) }\end{array}$ & $\begin{array}{l}\text { Chloride, } \\
\text { filtered } \\
\text { (mg/L) }\end{array}$ & $\begin{array}{c}\delta^{180} / \delta^{160} \\
\text { unfiltered } \\
\text { (per mil) }\end{array}$ & $\begin{array}{c}\delta^{2} \mathrm{H} / \delta^{1} \mathrm{H}, \\
\text { unfiltered } \\
\text { (per mil) }\end{array}$ \\
\hline \multicolumn{10}{|c|}{ Fox Hills-lower Hell Creek aquifer wells_-Continued } \\
\hline \multirow[t]{3}{*}{465721103300301} & \multirow{3}{*}{$\begin{array}{l}\text { 140-102-12BC (S Unit } \\
\text { Peaceful Valley Ranch } \\
\text { Well) }\end{array}$} & \multirow[t]{3}{*}{ SU_PcfvlyW } & $05 / 21 / 2018$ & 16.5 & 1,680 & 8.9 & 52.5 & -18.03 & -139.0 \\
\hline & & & 07/11/2018 & 18.4 & 1,760 & 8.5 & 52.5 & -18.19 & -140.0 \\
\hline & & & 09/19/2018 & 16.7 & 1,690 & 8.7 & 52.8 & -18.08 & -137.0 \\
\hline \multicolumn{10}{|c|}{ North Unit springs } \\
\hline \multirow[t]{3}{*}{473432103242801} & \multirow[t]{3}{*}{ Achenbach Spring } & \multirow[t]{3}{*}{ NU_AchSp } & $05 / 22 / 2018$ & 12.7 & 1,040 & 7.7 & 2.34 & -15.97 & -122.0 \\
\hline & & & 07/09/2018 & 15.7 & 1,080 & 8.0 & 2.38 & -15.97 & -122.0 \\
\hline & & & $09 / 21 / 2018$ & 11.5 & 1,020 & 9.0 & 2.36 & -15.98 & -122.0 \\
\hline \multirow[t]{3}{*}{473644103181901} & \multirow[t]{3}{*}{ Hagen Spring } & \multirow[t]{3}{*}{ NU_HgnSp } & $05 / 22 / 2018$ & 14.5 & 4,360 & 7.4 & 5.08 & -18.36 & -141.0 \\
\hline & & & 07/09/2018 & 15.7 & 4,300 & 7.8 & 4.87 & -18.42 & -142.0 \\
\hline & & & $09 / 21 / 2018$ & 10.8 & 3,180 & 8.0 & 5.06 & -18.38 & -142.0 \\
\hline \multirow[t]{2}{*}{473509103265101} & \multirow{2}{*}{$\begin{array}{l}\text { 147-100-05 (Mandal } \\
\text { Spring) }\end{array}$} & \multirow[t]{2}{*}{ NU_MndSp } & 07/11/2018 & 10.3 & 5,980 & 7.2 & 4.67 & -16.80 & -130.0 \\
\hline & & & 09/21/2018 & 10.4 & 5,900 & 7.3 & 4.48 & -16.72 & -131.0 \\
\hline \multirow[t]{3}{*}{473627103261601} & \multirow[t]{3}{*}{ Overlook Spring } & \multirow[t]{3}{*}{ NU_OvrlkSp } & $05 / 22 / 2018$ & 8.80 & 2,220 & 8.1 & 5.34 & -17.07 & -133.0 \\
\hline & & & 07/09/2018 & 9.70 & 2,350 & 8.2 & 4.90 & -17.08 & -133.0 \\
\hline & & & $09 / 21 / 2018$ & 9.60 & 2,240 & 8.2 & 4.90 & -17.05 & -133.0 \\
\hline \multirow[t]{3}{*}{473701103251401} & \multirow[t]{3}{*}{ Stevens Spring } & \multirow[t]{3}{*}{ NU_StvnSp } & $05 / 22 / 2018$ & 8.00 & 1,440 & 6.6 & 9.02 & -19.61 & -150.0 \\
\hline & & & 07/09/2018 & 9.30 & 1,610 & 6.5 & 9.29 & -19.60 & -150.0 \\
\hline & & & $09 / 21 / 2018$ & 8.90 & 1,500 & 6.7 & 9.03 & -19.51 & -150.0 \\
\hline \multicolumn{10}{|c|}{ South Unit springs } \\
\hline \multirow[t]{2}{*}{465807103235601} & \multirow[t]{2}{*}{ Boicourt Spring } & \multirow[t]{2}{*}{ SU_BoSp } & 07/10/2018 & 16.2 & 1,160 & 7.3 & 9.87 & -15.68 & -121.0 \\
\hline & & & 09/20/2018 & 8.70 & 1,040 & 8.4 & 12.7 & -14.21 & -105.0 \\
\hline \multirow[t]{3}{*}{465809103302201} & Big Plateau Spring & SU_BgPltSp & $05 / 21 / 2018$ & 19.7 & 2,220 & 7.3 & 9.30 & -16.87 & -131.0 \\
\hline & & & 07/08/2018 & 12.7 & 970 & 6.9 & 8.75 & -17.21 & -133.0 \\
\hline & & & 09/19/2018 & 11.9 & 1,770 & 6.9 & 8.89 & -17.27 & -134.0 \\
\hline
\end{tabular}


Table 3. Summary of water-chemistry results for samples collected from springs, streams, wells, and rain collectors in Theodore Roosevelt National Park, North Dakota.Continued

[Sample dates are given in month, day, and year (mm/dd/yyyy). USGS, U.S. Geological Survey; ${ }^{\circ} \mathrm{C}$, degree Celsius; $\mu \mathrm{S} / \mathrm{cm}$ at $25^{\circ} \mathrm{C}$, microsiemens per centimeter at 25 degrees Celsius; mg/L, milligram per liter; NU, North Unit; --, not measured; SU, South Unit; nr, near; ND, North Dakota; Cmpgrd, campground; S, South; SE, southeast]

\begin{tabular}{|c|c|c|c|c|c|c|c|c|c|}
\hline \multirow[b]{2}{*}{ USGS site number ${ }^{1}$} & \multirow[b]{2}{*}{ USGS site name ${ }^{1}$} & \multirow[b]{2}{*}{ Short name } & \multirow[b]{2}{*}{ Sample date } & \multicolumn{3}{|c|}{ Physical parameters } & \multicolumn{3}{|c|}{ Chemical constituents } \\
\hline & & & & $\begin{array}{c}\text { Water } \\
\text { temperature } \\
\left({ }^{\circ} \mathrm{C}\right)\end{array}$ & $\begin{array}{c}\text { Specific } \\
\text { conductance } \\
\text { ( } \mu \mathrm{S} / \mathrm{cm} \text { at } \\
\left.25^{\circ} \mathrm{C}\right)\end{array}$ & $\begin{array}{c}\text { pH } \\
\text { (standard } \\
\text { units) }\end{array}$ & $\begin{array}{l}\text { Chloride, } \\
\text { filtered } \\
\text { (mg/L) }\end{array}$ & $\begin{array}{c}\delta 180 / \delta^{160}, \\
\text { unfiltered } \\
\text { (per mil) }\end{array}$ & $\begin{array}{c}\delta^{2} \mathrm{H} / \delta^{1} \mathrm{H}, \\
\text { unfiltered } \\
\text { (per mil) }\end{array}$ \\
\hline \multicolumn{10}{|c|}{ South Unit springs-Continued } \\
\hline \multirow[t]{3}{*}{465856103334401} & Lone Tree Spring & SU_LnTrSp & $05 / 21 / 2018$ & 10.3 & 595 & 7.4 & 2.40 & -16.20 & -125.0 \\
\hline & & & 07/08/2018 & 17.9 & 587 & 6.9 & 2.40 & -16.22 & -125.0 \\
\hline & & & 09/19/2018 & 13.5 & 593 & 7.3 & 2.55 & -15.90 & -123.0 \\
\hline \multirow[t]{3}{*}{465726103224301} & Sheep Butte Spring & SU_ShpBtSp & $05 / 21 / 2018$ & -- & -- & -- & -- & -13.21 & -102.0 \\
\hline & & & 07/08/2018 & 17.7 & 1,330 & 7.4 & 10.0 & -13.08 & -100.0 \\
\hline & & & 09/19/2018 & -- & -- & -- & -- & -13.10 & -98.70 \\
\hline \multirow[t]{3}{*}{465909103320401} & Sheep Pasture Spring & SU_ShpPstSp & $05 / 21 / 2018$ & 17.4 & 660 & 7.6 & 6.08 & -15.19 & -118.0 \\
\hline & & & 07/08/2018 & 10.3 & 650 & 6.7 & 5.33 & -14.96 & -116.0 \\
\hline & & & 09/19/2018 & 11.2 & 1,130 & 6.8 & 5.36 & -14.70 & -114.0 \\
\hline \multirow[t]{3}{*}{465350103192901} & SE Corner Spring & SU_SECrnSp & $05 / 23 / 2018$ & 8.30 & 4,740 & 7.5 & 45.8 & -14.76 & -111.0 \\
\hline & & & 07/10/2018 & 9.90 & 4,960 & 6.9 & 55.1 & -14.78 & -112.0 \\
\hline & & & 09/21/2018 & 9.70 & 4,300 & 6.8 & 31.7 & -16.08 & -123.0 \\
\hline
\end{tabular}

1Data in this table are available from U.S. Geological Survey (2020) by using the site numbers. 
the upper Fort Union and Fox Hills-lower Hell Creek aquifers, and provide a review of the results of stable isotope data from rainfall collectors and streams.

\section{Range of Stable Isotope Compositions}

A total of 80 stable isotope samples were collected at springs, streams, wells, and rain collectors, and the distribution of $\delta^{2} \mathrm{H}$ and $\delta^{18} \mathrm{O}$ values varied by site type (table 3). The $\delta^{2} \mathrm{H}$ values for all 80 samples were between -156.00 and -58.10 per mil (\%), with a mean of $-124.80 \%$ and standard deviation of $26.03 \%$. The $\delta^{18} \mathrm{O}$ values for all 80 samples were between -20.27 and $-6.69 \%$, with a mean of -16.08 and standard deviation of $3.57 \%$. The $\delta^{2} \mathrm{H}$ and $\delta^{18} \mathrm{O}$ values for North Unit spring samples ranged from -150.00 to $-122.00 \%$ and -19.61 to $-15.97 \%$, respectively. The $\delta^{2} \mathrm{H}$ and $\delta^{18} \mathrm{O}$ values for South Unit spring samples ranged from -134.00 to $-98.70 \%$ and -17.27 to $-13.08 \%$, respectively. The $\delta^{2} \mathrm{H}$ and $\delta^{18} \mathrm{O}$ values for stream samples ranged from -121.00 to $-75.50 \%$ and -14.84 to $-8.73 \%$, respectively. The $\delta^{2} \mathrm{H}$ and $\delta^{18} \mathrm{O}$ values for shallow alluvial aquifer samples (NU_WldlfW) ranged from -129.00 to $-128.00 \%$ and -16.90 to $-16.60 \%$, respectively (table 3 ). The $\delta^{2} \mathrm{H}$ and $\delta^{18} \mathrm{O}$ values for upper Fort Union aquifer samples ranged from -156.00 to $-151.00 \%$ and -20.27 to $-19.70 \%$, respectively. The $\delta^{2} \mathrm{H}$ and $\delta^{18} \mathrm{O}$ values for Fox Hills-lower Hell Creek aquifer samples ranged from -142.00 to $-137.00 \%$ and -18.32 to $-18.01 \%$, respectively (table 3 ). The $\delta^{2} \mathrm{H}$ and $\delta^{18} \mathrm{O}$ values from North Unit rain collector samples ranged from -116.00 to $-58.1 \%$ and -13.09 to $-6.69 \%$, respectively. The $\delta^{2} \mathrm{H}$ and $\delta^{18} \mathrm{O}$ values from South Unit rain collector samples ranged from -104.00 to $-62.79 \%$ and -14.22 to $-9.57 \%$, respectively.

\section{Comparison with Global Meteoric Waters}

The $\delta^{2} \mathrm{H}$ and $\delta^{18} \mathrm{O}$ values at each sample site collected May-September 2018 were plotted with the GMWL defined by Craig (1961; figs. 7, 8, 9). Most samples plotted below the GMWL; therefore, a LMWL was calculated for the study area (figs. 7, 8, 9). Linear regression was used to determine a LMWL that related $\delta^{2} \mathrm{H}$ to $\delta^{18} \mathrm{O}$ for the 10 precipitation samples at the North and South Units of the park collected between May and September 2018 (table 3). Equation 3 is the LMWL for the study area during May-September 2018:

$$
\delta^{2} \mathrm{H}=7.86 \times \delta^{18} \mathrm{O}+1.05
$$

The LMWL plotted below the GMWL (figs. 7, 8, 9). All isotope samples, except for one precipitation sample in May 2018 (fig. 7), plotted below the GMWL and were depleted in heavy isotopes (more negative $\delta^{2} \mathrm{H}$ and $\delta^{18} \mathrm{O}$ values) because of environmental factors.

Three environmental factors likely influencing the $\delta^{2} \mathrm{H}$ and $\delta^{18} \mathrm{O}$ composition of precipitation in the study area are the latitude, continental position, and altitude effects (Dansgaard,
1964; Rozanski and others, 1993; fig. 5). The latitude effect is a product of the major global source of water vapor in the atmosphere originating from tropical oceans between $30^{\circ} \mathrm{S}$ and $30^{\circ} \mathrm{N}$ (Rozanski and others, 1993). Precipitation during poleward movement of air masses originating from low latitudes causes gradual reduction of the total precipitable water and a depletion (more negative values) in heavy isotopes $\left({ }^{18} \mathrm{O}\right.$ and ${ }^{2} \mathrm{H}$ ), which are preferentially precipitated because of their greater mass (Dansgaard, 1964; Rozanski and others, 1993). The continental effect acts similarly to the latitude effect - the amount of available moisture and heavy isotopes are reduced (depleted) as air masses move farther inland from coastlines (Rozanski and others, 1993). The altitude effect is the tendency of stable isotopes to mimic topography with more depleted (lighter) isotopes observed in high-altitude, mountainous areas (Rozanski and others, 1993).

The most notable influences on the $\delta^{2} \mathrm{H}$ and $\delta^{18} \mathrm{O}$ compositions in the North and South Units of the park were from the latitude and continental effects because both units are at high latitudes (between 46 and 48 degrees latitude; table 1) and are near the center of the North American continent. The great distance from low latitudes and coastlines to both units of the park likely resulted in greater depletion of heavy isotopes for rain collector samples relative to studies at low latitudes or closer to coastlines (Dansgaard, 1964; Gat and Gonfiantini, 1981). The differences between the slope and y-axis intercept of the GMWL and the LMWL may be from evaporation of rain collector samples before the samples were collected and sent for analysis. Evaporation effects were observed for samples from streams and shallow groundwater because they plotted below the GMWL in stable isotope plots from May to September 2018 (figs. 7, 8, 9). The altitude effect was not observed for samples from rain collectors in the North and South Units of the park likely because the altitude difference between the two units is only about $250 \mathrm{ft}$ (table 1). Clark and Fritz (1997) reported that the $\delta^{2} \mathrm{H}$ and $\delta^{18} \mathrm{O}$ composition of precipitation generally varies from about $-1 \%$ to $-4 \%$ and $-0.15 \%$ to $-0.5 \%$, respectively, for every 100 -meter increase in altitude.

\section{Springs and the Wildlife Well}

Samples from springs and the Wildlife well were qualitatively assessed to evaluate water composition for springs using stable isotope plots in May, July, and September 2018 (figs. 7, $8,9)$. The $\delta^{2} \mathrm{H}$ and $\delta^{18} \mathrm{O}$ values of the springs and the Wildlife well (NU_WldlfW) were intermediate and plotted close to the LMWL between upper Fort Union aquifer and rain collector samples. The intermediate stable isotopic composition of springs indicated a mixture of groundwater and precipitation (figs. 7, 8, 9); however, the contribution from groundwater and precipitation varied for each spring. The qualitative assessment was made by observing the proximity to which spring samples plotted near upper Fort Union aquifer (groundwater) or rain collector samples (precipitation). No spring samples 


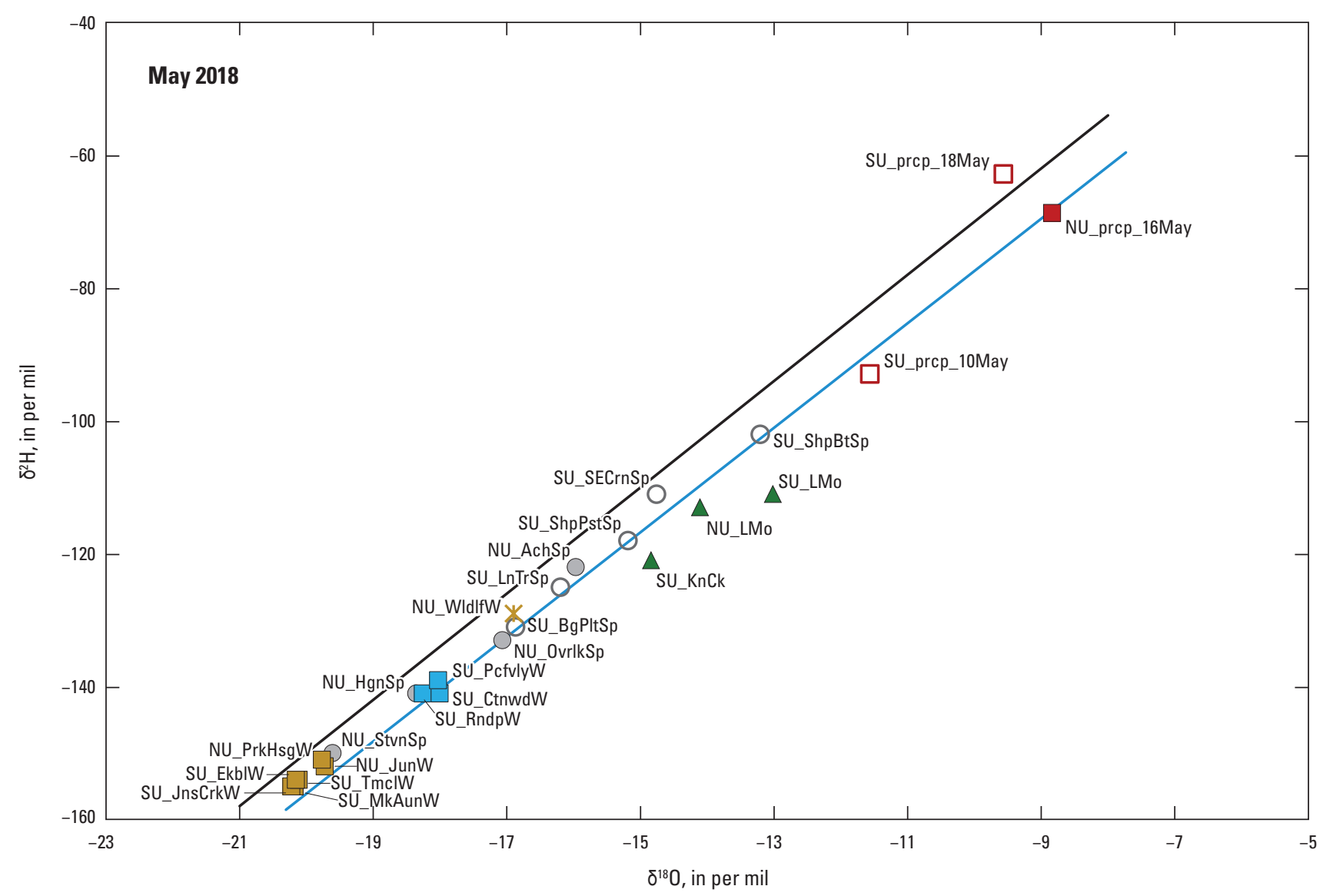

EXPLANATION

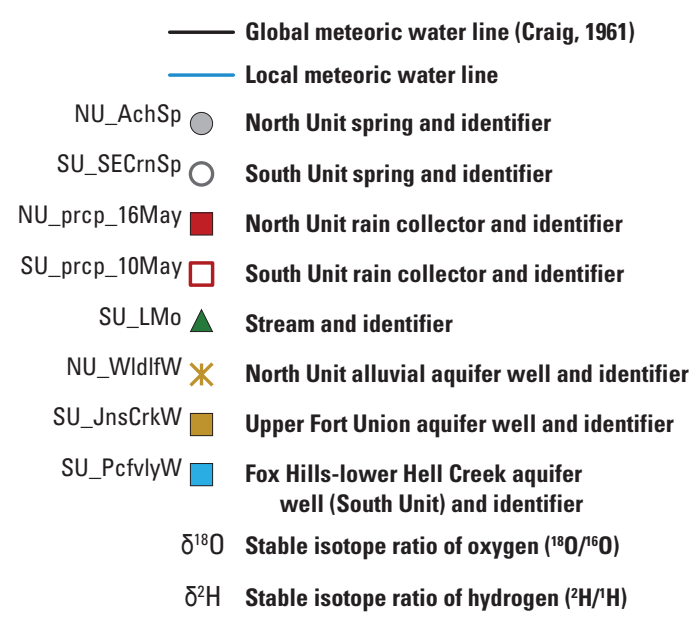

Figure 7. Stable isotope plot of water samples collected in May 2018 in Theodore Roosevelt National Park.

were sourced solely from groundwater or precipitation; however, spring samples generally plotted closer to upper Fort Union aquifer samples than rain collector samples (figs. $7,8,9)$. Spring samples proximal to upper Fort Union aquifer samples were from Stevens Spring (NU_StvnSp), Hagan Spring (NU_HgnSp), Big Plateau Spring (SU_BgPltSp), and Overlook Spring (NU_OvrlkSp; figs. 7, 8, 9). The Wildlife well (NU_WldlfW) also was proximal to upper Fort Union aquifer samples (figs. 7, 8, 9). Spring samples proximal to rain collector samples were from Sheep Butte Spring (SU_ShpBtSp), Southeast Corner Spring (SU_SECrnSp), and Sheep Pasture Spring (SU_ShpPstSp; figs. 7, 8, 9).

The variability of $\delta^{2} \mathrm{H}$ and $\delta^{18} \mathrm{O}$ values from some springs was observed in monthly stable isotope plots for MaySeptember 2018 (figs. 7, 8, 9). Springs that showed discernable monthly changes were Boicourt Spring (SU_BoSp), 


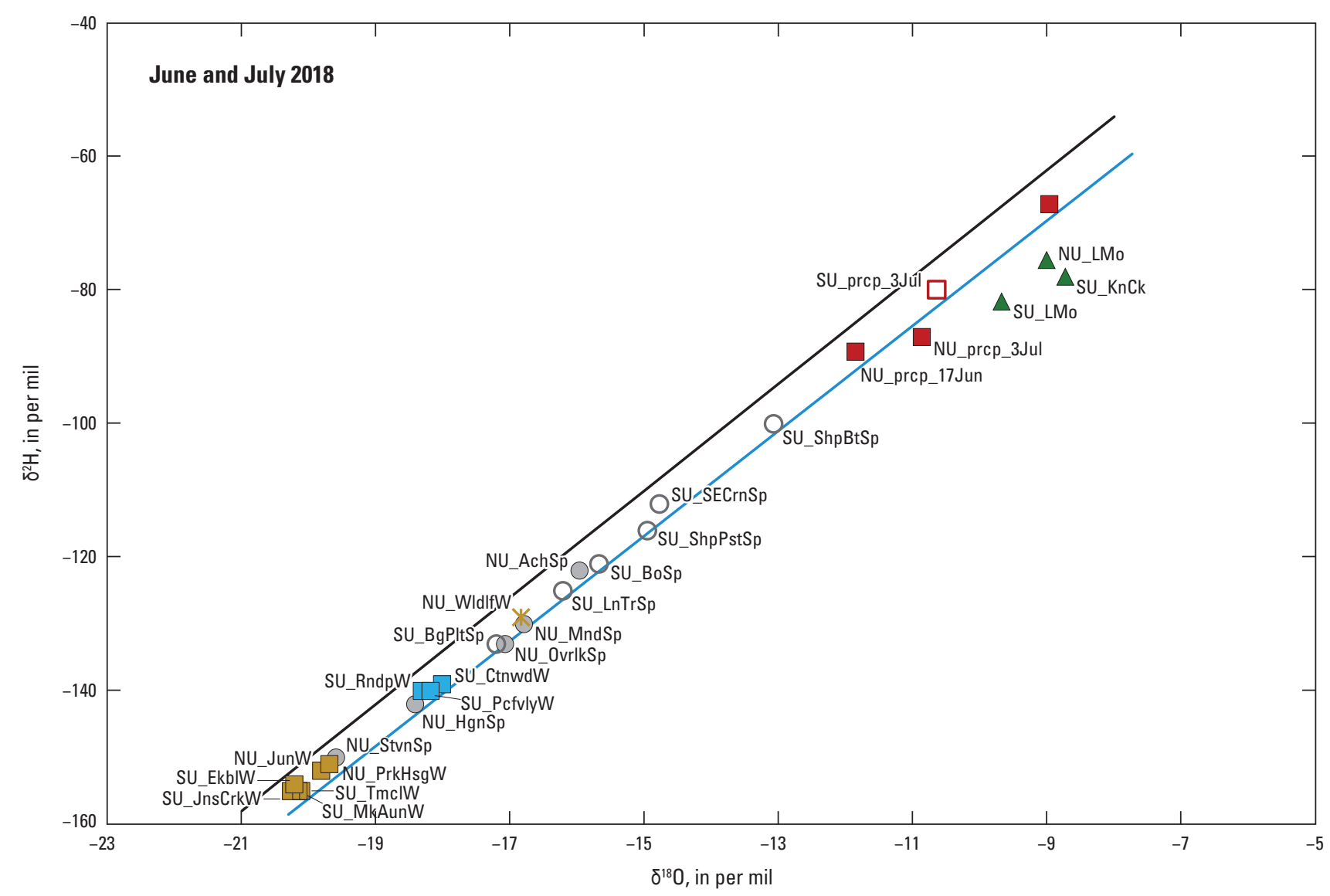

EXPLANATION

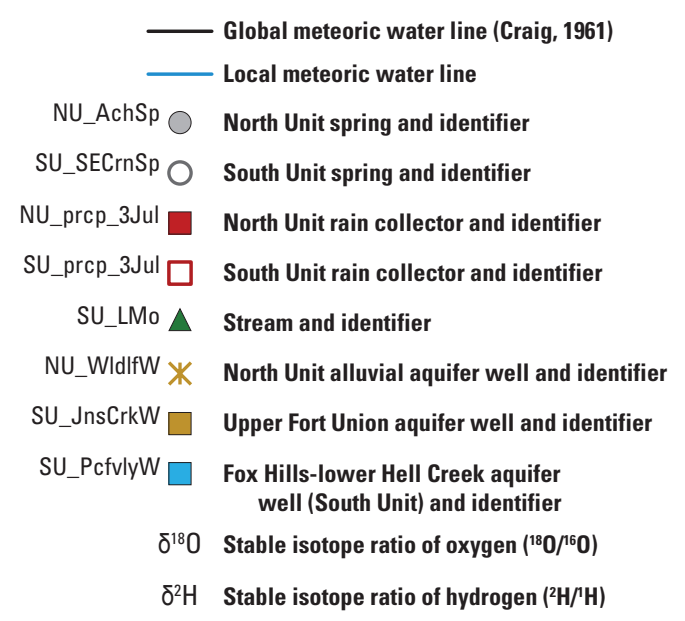

Figure 8. Stable isotope plot of water samples collected in June and July 2018 in Theodore Roosevelt National Park.

Southeast Corner Spring (SU_SECrnSp), and Sheep Pasture Spring (SU_ShpPstSp). The variance in $\delta^{2} \mathrm{H}$ and $\delta^{18} \mathrm{O}$ values was likely due to changes in the contribution from the upper Fort Union aquifer or precipitation related to (1) the elapsed time between precipitation events and sample collection, and (2) the residence time of infiltrated precipitation before being discharged at the spring. Spring samples collected soon after precipitation events that were enriched in heavy isotopes would indicate a shorter residence time (fast groundwater movement) if the $\delta^{2} \mathrm{H}$ and $\delta^{18} \mathrm{O}$ values of the spring sample were close to the precipitation $\delta^{2} \mathrm{H}$ and $\delta^{18} \mathrm{O}$ values. Spring samples collected soon after precipitation events that were depleted in heavy isotopes compared to precipitation samples would indicate a longer residence time (slow groundwater movement) of water in the aquifer where the infiltrated precipitation had not yet reached the spring; however, infiltrated 


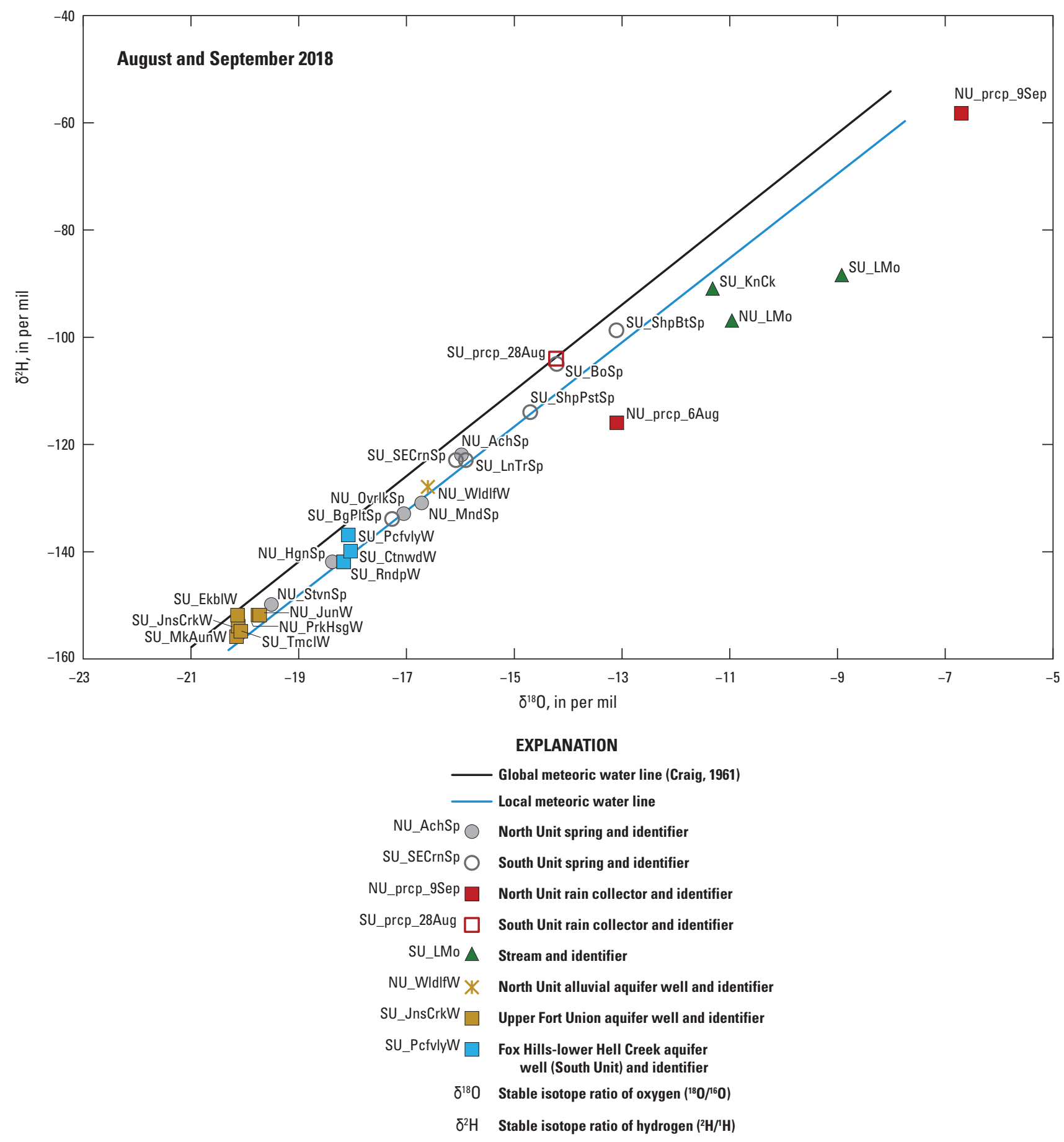

Figure 9. Stable isotope plot of water samples collected in August and September 2018 in Theodore Roosevelt National Park.

precipitation mixed with depleted groundwater could potentially obscure the $\delta^{2} \mathrm{H}$ and $\delta^{18} \mathrm{O}$ values of infiltrated precipitation. A long residence time also may explain variable $\delta^{2} \mathrm{H}$ and $\delta^{18} \mathrm{O}$ values as water discharging from springs on each collection date could be from recharge sources that occurred at different times (spring snowmelt or summer rains). Stable isotope data collected from additional recharge sources (snowmelt and streams close to springs) and more frequently at springs could potentially estimate residence time of water sources at each spring. 


\section{Upper Fort Union and Fox Hills-Lower Hell Creek Aquifers}

The depleted $\delta^{2} \mathrm{H}$ and $\delta^{18} \mathrm{O}$ values of groundwater samples in monthly stable isotope plots for May-September 2018 (figs. 7, 8, 9) provided insight on recharge mechanisms for the upper Fort Union and Fox Hills-lower Hell Creek aquifers. The upper Fort Union and Fox Hills-lower Hell Creek aquifers were depleted in heavy isotopes relative to springs, streams, shallow groundwater, and precipitation from rain collectors. Evaporation cannot explain the depleted groundwater samples because evaporation preferentially removes lighter isotopes and leaves behind heavier isotopes (Rozanski and others, 1993). Isotopic compositions typically do not change after precipitation has infiltrated into the ground (Gat, 1971); therefore, some other source or process was responsible for the depleted groundwater samples.

Gat (1971) provided several explanations that could account for groundwater samples being depleted in heavy isotopes. The first explanation is both aquifers contain large fractions of older water from past climates characterized by colder temperatures and snow containing lighter, more depleted waters, like the isotopic composition of snow and ice from modern Arctic and Antarctic environments (Gat, 1971; Rozanski and others, 1993). Aquifer recharge could have been sourced from glaciers during continental glaciation of the Pleistocene Epoch when the climate was colder than the modern climate. Matheney and Gerla (1996) reported that meltwater runoff from glacial ice was a likely source of recharge to the Dakota aquifer in the Cretaceous-age Dakota Sandstone near Grand Forks, N. Dak. (about 300 mi east of the study area). The second explanation is heavy rainfall, which generally is depleted in heavy isotopes, provides recharge to the springs in the study area. The study area typically does not receive steady heavy rainfall; however, Vogel and Van Urk (1975) and Rehm and others (1982) determined that heavy rainfall was an important source of recharge for aquifers in semiarid regions. The third explanation is that snowfall and snowmelt are primary recharge sources for the aquifers. Tian and others (2018) observed depleted $\delta^{2} \mathrm{H}$ and $\delta^{18} \mathrm{O}$ values in snowfall relative to spring, summer, and fall precipitation (fig. 5). Rehm and others (1982) also noticed that snow and snowmelt were depleted in heavy isotopes while investigating groundwater recharge to the Sentinel Butte Formation (part of the upper Fort Union aquifer) in central North Dakota.

The second and third explanations best account for the heavy isotope depletion observed in the upper Fort Union and Fox Hills-lower Hell Creek aquifers because groundwater samples plot along the LMWL, which indicated that both aquifers are recharged from recent meteoric sources. Rehm and others (1982) evaluated recharge in the upper Fort Union aquifer in an environment similar to Theodore Roosevelt National Park and observed that most recharge occurred during the late spring and fall after heavy precipitation events, when the ground was not frozen, and when plants were not transpiring large amounts of water. Another important source of recharge observed by Rehm and others (1982) was land surface depressions (relatively flat areas where water pools). Precipitation and snowmelt (depleted in heavy isotopes) from higher elevation areas flow overland and become concentrated in depressions of variable size where water has greater time to infiltrate. The North and South Units of the park have ideal conditions for land surface depression recharge because of the hilly and variable topography of both units.

\section{Streams and Rain Collectors}

The $\delta^{2} \mathrm{H}$ and $\delta^{18} \mathrm{O}$ values from streams generally were enriched and variable compared to spring and groundwater samples for monthly stable isotopes plots for MaySeptember 2018 (figs. 7, 8, 9). Stream samples were more depleted in heavy isotopes than rain collector samples in May 2018 (fig. 7). Possible explanations for the depleted May 2018 stream samples could be because (1) enriched precipitation events were not captured in stream samples because of the time elapsed before sample collection, (2) groundwater discharge being a major contributor to streamflow, or (3) heavy rainfall or spring snowmelt (both depleted in heavy isotopes) were contributing to streamflow. A combination of these three explanations best accounts for depleted stream samples in May 2018 because stream samples were collected nearly 1 week after precipitation events, and hydrographs from streamgages in the North and South Units indicate snowmelt from March and April 2018 contributed to streamflow as direct runoff and likely discharge from alluvial aquifers or the upper Fort Union aquifer.

The $\delta^{2} \mathrm{H}$ and $\delta^{18} \mathrm{O}$ values from stream samples from July 2018 (fig. 8) were more enriched and less variable than samples from May 2018 (fig. 7). Stream samples from July 2018 (fig. 8) plotted close to rain collector samples and exhibited tighter grouping (less variability of $\delta^{2} \mathrm{H}$ and $\delta^{18} \mathrm{O}$ values) than in May 2018 (fig. 7). Stream samples collected July 9-11, 2018, after sampled precipitation events from late May 2018, June 17, 2018, and July 3, 2018, had similar $\delta^{2} \mathrm{H}$ and $\delta^{18} \mathrm{O}$ values (table 3; fig. 8). The precipitation event responsible for enriched $\delta^{2} \mathrm{H}$ and $\delta^{18} \mathrm{O}$ values in stream samples from July 2018 was difficult to determine because prior precipitation events did not have distinct $\delta^{2} \mathrm{H}$ and $\delta^{18} \mathrm{O}$ values; however, the enriched $\delta^{2} \mathrm{H}$ and $\delta^{18} \mathrm{O}$ values indicated that groundwater was not a major contributor.

Stream and rain collector samples from September 2018 (fig. 9) did not group together when plotted, and the stream samples were depleted in heavy isotopes compared to stream samples from July 2018 (fig. 8). Stream samples were collected on September 19-20, 2019, about 10 days after rain collector samples from September 9, 2018, and had similar $\delta^{2} \mathrm{H}$ and $\delta^{18} \mathrm{O}$ values as rain collector samples from June 17, 2018, and July 3, 2018 (fig. 8). The depletion in heavy isotopes from July to September 2018 can be explained from either (1) greater percent contribution from depleted groundwater or (2) less precipitation events and greater evaporation (evaporation preferentially removes lighter isotopes). Anna (1981) 
observed that streamflow in the Little Missouri River and its tributaries was affected mostly by groundwater at low-flow conditions during late summer, fall, and winter, which could explain the depletion of stream samples in September 2018.

\section{Recharge Rate and Percent Recharge Estimates from Chloride Mass Balance}

The CMB method was used to estimate recharge rates and percent recharge for all springs in the park and the Wildlife well (NU_WldlfW). Table 4 lists recharge rate estimates and percent recharge for the 12-day period before sampling. Recharge for springs and the Wildlife well (NU_WldlfW) in the North Unit of the park ranged from 0.001 to 0.065 inch (in.) during the 12-day period (table 4). Recharge for springs in the South Unit of the park ranged from 0.001 to $0.074 \mathrm{in.} \mathrm{during}$ the 12 -day period (table 4). The percent recharge during the 12-day period for the North and South Units of the park ranged from 0.51 to 2.82 percent and from 0.11 to 2.75 percent, respectively (table 4). Estimated mean annual recharge rates for the North and South Units of the Park were 0.51 and 0.35 inch per year, respectively. The springs with the highest annual mean recharge from precipitation were Mandal Spring (North Unit; NU_MndSp) and Lone Tree Spring (South Unit; SU_LnTrSp). The spring with the lowest annual mean recharge from precipitation was SE Corner Spring (SU_SECrnSp).

The CMB method was used to compare 12-day recharge rates and 12-day percent recharge estimates among springs and one alluvial well with several assumptions. The assumptions listed in Wood (1999) and Brooks and Mason (2005) were addressed earlier; however, another assumption was recognized. The assumption was the 12-day period before sampling accurately represented the time required for springs to observe water-chemistry changes from precipitation events. Estimates were calculated for the 12-day period before sampling using the time delay between groundwater levels, measured at a single well in an unconfined part of the upper Fort Union aquifer, and cumulative precipitation (fig. 6). Recharge to alluvial aquifers may have faster recharge rates than 12 days, whereas confined aquifers or aquifers deeper than alluvial systems may have slower recharge rates than 12 days. However, the 12-day period can be used assuming that chloride is conserved during infiltration and along groundwater flow paths. The assumption is valid for this study because chloride concentrations in precipitation events were relatively constant, and both units of the park received few rainfall events during the 12-day period. Despite the many assumptions, the 12-day recharge rate and 12-day percent recharge estimate can be used as a relative comparison tool among springs to explain recharge sources and recharge mechanisms for aquifers.

The 12-day recharge rate, 12-day percent recharge, and chloride concentration of springs were interpreted to determine the primary source of recharge and possible recharge mechanisms for aquifers supplying springs. Spring samples with high 12-day recharge rates, high 12-day percent recharge, and low chloride concentration could indicate recharge was primarily from quickly infiltrated precipitation (low evaporation) that traveled rapidly along groundwater flow paths. Springs with low 12-day recharge rates, low 12-day percent recharge, and high chloride concentrations may indicate water sources from groundwater (or heavily mixed with groundwater) or recharge was primarily from slowly infiltrated precipitation (high evaporation) that traveled slowly along groundwater flow paths. Other mechanisms that could influence recharge rates, percent recharge, and chloride concentrations include (1) distance from the recharge area to the spring, (2) aquifer conditions (confined, semiconfined, and unconfined), (3) geochemistry of aquifer materials (marine versus terrestrial deposits), and (4) evaporation effects for samples from spring pools (increased chloride concentration).

Achenbach Spring (NU_AchSp), Lone Tree Spring (SU_ LnTrSp), and Mandal Spring (NU_MndSp) had above-mean 12-day recharge rates and 12-day percent recharge and belowmean chloride concentrations during the study period (table 4; fig. 10). These springs likely receive water from quickly infiltrated precipitation with short aquifer residence time between the recharge area and spring. Quick infiltration may be associated with an unconfined aquifer and the short residence time could result from either high hydraulic conductivity or short groundwater flow paths (recharge area proximal to the spring). All three springs showed the lowest chloride concentrations of all springs in the study, which indicated lower contributions (or lower mixing) of high chloride groundwater from the upper Fort Union aquifer, quick infiltration, low evaporation, or faster groundwater movement (little effect from aquifer materials) than waters contributing to other springs.

Southeast Corner Spring (SU_SECrnSp), Stevens Spring (NU_StvnSp), Big Plateau Spring (SU_BgPltSp), Boicourt Spring (SU_BoSp), and Sheep Butte Spring (SU_ShpBtSp) had mostly below-mean 12-day recharge rates and 12-day percent recharge, and above-mean chloride concentrations during the study period (table 4; fig. 10). These springs indicated greater influences of slowly infiltrated precipitation with long residence time from recharge areas to springs. The slow infiltration could be associated with a semiconfined or confined aquifer and the long residence time may result from either low hydraulic conductivity or long groundwater flow paths (recharge area distant to the spring). All five springs showed the highest chloride concentrations among all springs in the study, indicating greater contributions or mixing of high chloride groundwater from the upper Fort Union aquifer, greater evaporation, or slower groundwater movement (high effects from aquifer materials) than waters contributing to other springs. The chloride concentration of Southeast Corner Spring (SU_SECrnSp) was 2.5 to nearly 4.5 times greater than the next highest chloride concentration at Boicourt Spring (SU_BoSp; table 4). The above-mean chloride concentration at Southeast Corner Spring (SU_SECrnSp; fig. 10) likely resulted from its sample collection from pooled water that was subject to evaporation and subsequent concentration of 
Table 4. Summary of chloride-mass balance results, including the 12-day recharge rate, 12-day percent recharge, and annual recharge rate estimates for springs and one alluvial well.

[Sample dates are given in month, day, and year (mm/dd/yyyy). in., inch; mg/L, milligram per liter; \%, percent; in/yr, inch per year]

\begin{tabular}{|c|c|c|c|c|c|c|c|c|c|}
\hline USGS site name ${ }^{1}$ & Short name & Sample date & $\begin{array}{c}\text { Chloride } \\
\text { concentration for } \\
\text { spring or well from } \\
\text { table } 3(\mathrm{mg} / \mathrm{L})\end{array}$ & $\begin{array}{l}\text { 12-day } \\
\text { precipitation } \\
\text { (in.) }\end{array}$ & $\begin{array}{c}\text { 12-day } \\
\text { mean chloride } \\
\text { concentration } \\
\text { of precipitation } \\
(\mathrm{mg} / \mathrm{L})\end{array}$ & $\begin{array}{l}\text { 12-day } \\
\text { recharge } \\
\text { estimate to the } \\
\text { spring or well } \\
\text { (in.) }\end{array}$ & $\begin{array}{l}\text { 12-day } \\
\text { recharge } \\
(\%)\end{array}$ & $\begin{array}{l}\text { Annual recharge to } \\
\text { spring or well from } \\
\text { precipitation } \\
\text { (in/yr) }\end{array}$ & $\begin{array}{l}\text { Annual mean } \\
\text { recharge from } \\
\text { precipitation } \\
\text { (in/yr) }\end{array}$ \\
\hline \multicolumn{10}{|c|}{ North Unit alluvium well } \\
\hline \multirow[t]{3}{*}{ 147-099-04AC } & \multirow[t]{3}{*}{ NU_WldlfW } & $05 / 22 / 2018$ & 8.24 & 0.34 & 0.07 & 0.003 & 0.80 & 0.08 & \multirow[t]{3}{*}{0.34} \\
\hline & & 07/09/2018 & 5.41 & 2.55 & 0.06 & 0.029 & 1.12 & 0.87 & \\
\hline & & 09/20/2018 & 5.34 & 0.29 & 0.05 & 0.003 & 0.87 & 0.08 & \\
\hline \multicolumn{10}{|c|}{ North Unit springs } \\
\hline \multirow{3}{*}{$\begin{array}{l}\text { Achenbach } \\
\text { Spring }\end{array}$} & \multirow{3}{*}{ NU_AchSp } & $05 / 22 / 2018$ & 2.34 & 0.34 & 0.07 & 0.010 & 2.82 & 0.29 & \multirow[t]{3}{*}{0.79} \\
\hline & & 07/09/2018 & 2.38 & 2.55 & 0.06 & 0.065 & 2.54 & 1.97 & \\
\hline & & 09/21/2018 & 2.36 & 0.18 & 0.05 & 0.004 & 1.97 & 0.11 & \\
\hline \multirow[t]{3}{*}{ Hagen Spring } & \multirow[t]{3}{*}{ NU_HgnSp } & $05 / 22 / 2018$ & 5.08 & 0.34 & 0.07 & 0.004 & 1.30 & 0.13 & \multirow[t]{3}{*}{0.38} \\
\hline & & 07/09/2018 & 4.87 & 2.55 & 0.06 & 0.032 & 1.24 & 0.96 & \\
\hline & & $09 / 21 / 2018$ & 5.06 & 0.18 & 0.05 & 0.002 & 0.92 & 0.05 & \\
\hline \multirow{2}{*}{$\begin{array}{l}\text { 147-100-05 } \\
\text { (Mandal } \\
\text { Spring) }\end{array}$} & \multirow[t]{2}{*}{ NU_MndSp } & $07 / 11 / 2018$ & 4.67 & 3.45 & 0.08 & 0.061 & 1.76 & 1.85 & \multirow[t]{2}{*}{0.95} \\
\hline & & $09 / 21 / 2018$ & 4.48 & 0.18 & 0.05 & 0.002 & 1.04 & 0.06 & \\
\hline \multirow[t]{3}{*}{ Overlook Spring } & \multirow[t]{3}{*}{ NU_OvrlkSp } & $05 / 22 / 2018$ & 5.34 & 0.34 & 0.07 & 0.004 & 1.24 & 0.13 & \multirow[t]{3}{*}{0.38} \\
\hline & & 07/09/2018 & 4.9 & 2.55 & 0.06 & 0.031 & 1.24 & 0.96 & \\
\hline & & 09/21/2018 & 4.9 & 0.18 & 0.05 & 0.002 & 0.95 & 0.05 & \\
\hline \multirow[t]{3}{*}{ Stevens Spring } & \multirow[t]{3}{*}{ NU_StvnSp } & $05 / 22 / 2018$ & 9.02 & 0.34 & 0.07 & 0.002 & 0.73 & 0.08 & \multirow[t]{3}{*}{0.20} \\
\hline & & 07/09/2018 & 9.29 & 2.55 & 0.06 & 0.017 & 0.65 & 0.51 & \\
\hline & & $09 / 21 / 2018$ & 9.03 & 0.18 & 0.05 & 0.001 & 0.51 & 0.03 & \\
\hline \multicolumn{10}{|c|}{ South Unit springs } \\
\hline \multirow[t]{2}{*}{ Boicourt Spring } & \multirow[t]{2}{*}{ SU_BoSp } & 07/10/2018 & 9.87 & 1.34 & 0.06 & 0.008 & 0.61 & 0.25 & \multirow[t]{2}{*}{0.17} \\
\hline & & 09/20/2018 & 12.7 & 0.88 & 0.05 & 0.003 & 0.37 & 0.10 & \\
\hline \multirow{3}{*}{$\begin{array}{l}\text { Big Plateau } \\
\text { Spring }\end{array}$} & \multirow[t]{3}{*}{ SU_BgPltSp } & $05 / 21 / 2018$ & 9.3 & 0.22 & 0.07 & 0.002 & 0.71 & 0.05 & \multirow[t]{3}{*}{0.24} \\
\hline & & 07/08/2018 & 8.75 & 2.94 & 0.06 & 0.020 & 0.69 & 0.62 & \\
\hline & & 09/19/2018 & 8.89 & 0.33 & 0.05 & 0.002 & 0.52 & 0.05 & \\
\hline
\end{tabular}


Table 4. Summary of chloride-mass balance results, including the 12-day recharge rate, 12-day percent recharge, and annual recharge rate estimates for springs and one alluvial well.-Continued

[Sample dates are given in month, day, and year (mm/dd/yyyy). in., inch; $\mathrm{mg} / \mathrm{L}$, milligram per liter; \%, percent; in/yr, inch per year]

\begin{tabular}{|c|c|c|c|c|c|c|c|c|c|}
\hline USGS site name ${ }^{1}$ & Short name & Sample date & $\begin{array}{c}\text { Chloride } \\
\text { concentration for } \\
\text { spring or well from } \\
\text { table } 3 \text { (mg/L) }\end{array}$ & $\begin{array}{c}\text { 12-day } \\
\text { precipitation } \\
\text { (in.) }\end{array}$ & $\begin{array}{c}\text { 12-day } \\
\text { mean chloride } \\
\text { concentration } \\
\text { of precipitation } \\
(\mathrm{mg} / \mathrm{L})\end{array}$ & $\begin{array}{l}\text { 12-day } \\
\text { recharge } \\
\text { estimate to the } \\
\text { spring or well } \\
\text { (in.) }\end{array}$ & $\begin{array}{c}\text { 12-day } \\
\text { recharge } \\
(\%)\end{array}$ & $\begin{array}{l}\text { Annual recharge to } \\
\text { spring or well from } \\
\text { precipitation } \\
\text { (in/yr) }\end{array}$ & $\begin{array}{c}\text { Annual mean } \\
\text { recharge from } \\
\text { precipitation } \\
\text { (in/yr) }\end{array}$ \\
\hline \multicolumn{10}{|c|}{ South Unit springs-Continued } \\
\hline \multirow[t]{3}{*}{ Lone Tree Spring } & \multirow[t]{3}{*}{ SU_LnTrSp } & $05 / 21 / 2018$ & 2.4 & 0.22 & 0.07 & 0.006 & 2.75 & 0.18 & \multirow[t]{3}{*}{0.87} \\
\hline & & 07/08/2018 & 2.4 & 2.94 & 0.06 & 0.074 & 2.52 & 2.25 & \\
\hline & & $09 / 19 / 2018$ & 2.55 & 0.33 & 0.05 & 0.006 & 1.82 & 0.18 & \\
\hline \multirow{3}{*}{$\begin{array}{l}\text { Sheep Butte } \\
\text { Spring }\end{array}$} & \multirow[t]{3}{*}{ SU_ShpBtSp } & $05 / 21 / 2018$ & -- & 0.54 & 0.07 & & & & \multirow[t]{3}{*}{0.39} \\
\hline & & $07 / 08 / 2018$ & 10 & 2.13 & 0.06 & 0.013 & 0.61 & 0.39 & \\
\hline & & 09/19/2018 & -- & 0.15 & 0.05 & & & & \\
\hline \multirow{3}{*}{$\begin{array}{l}\text { Sheep Pasture } \\
\text { Spring }\end{array}$} & \multirow{3}{*}{$\begin{array}{l}\text { SU_ShpPst- } \\
\text { Sp }\end{array}$} & $05 / 21 / 2018$ & 6.08 & 0.54 & 0.07 & 0.002 & 1.09 & 0.07 & \multirow[t]{3}{*}{0.39} \\
\hline & & $07 / 08 / 2018$ & 5.33 & 2.13 & 0.06 & 0.033 & 1.14 & 1.02 & \\
\hline & & 09/19/2018 & 5.36 & 0.15 & 0.05 & 0.003 & 0.87 & 0.09 & \\
\hline \multirow{3}{*}{$\begin{array}{l}\text { SE Corner } \\
\text { Spring }\end{array}$} & \multirow[t]{3}{*}{ SU_SECrnSp } & $05 / 23 / 2018$ & 45.8 & 0.68 & 0.08 & 0.001 & 0.17 & 0.04 & \multirow[t]{3}{*}{0.04} \\
\hline & & $07 / 10 / 2018$ & 55.1 & 1.34 & 0.06 & 0.001 & 0.11 & 0.04 & \\
\hline & & 09/21/2018 & 31.7 & 0.88 & 0.05 & 0.001 & 0.15 & 0.04 & \\
\hline
\end{tabular}

1U.S. Geological Survey (2020). 

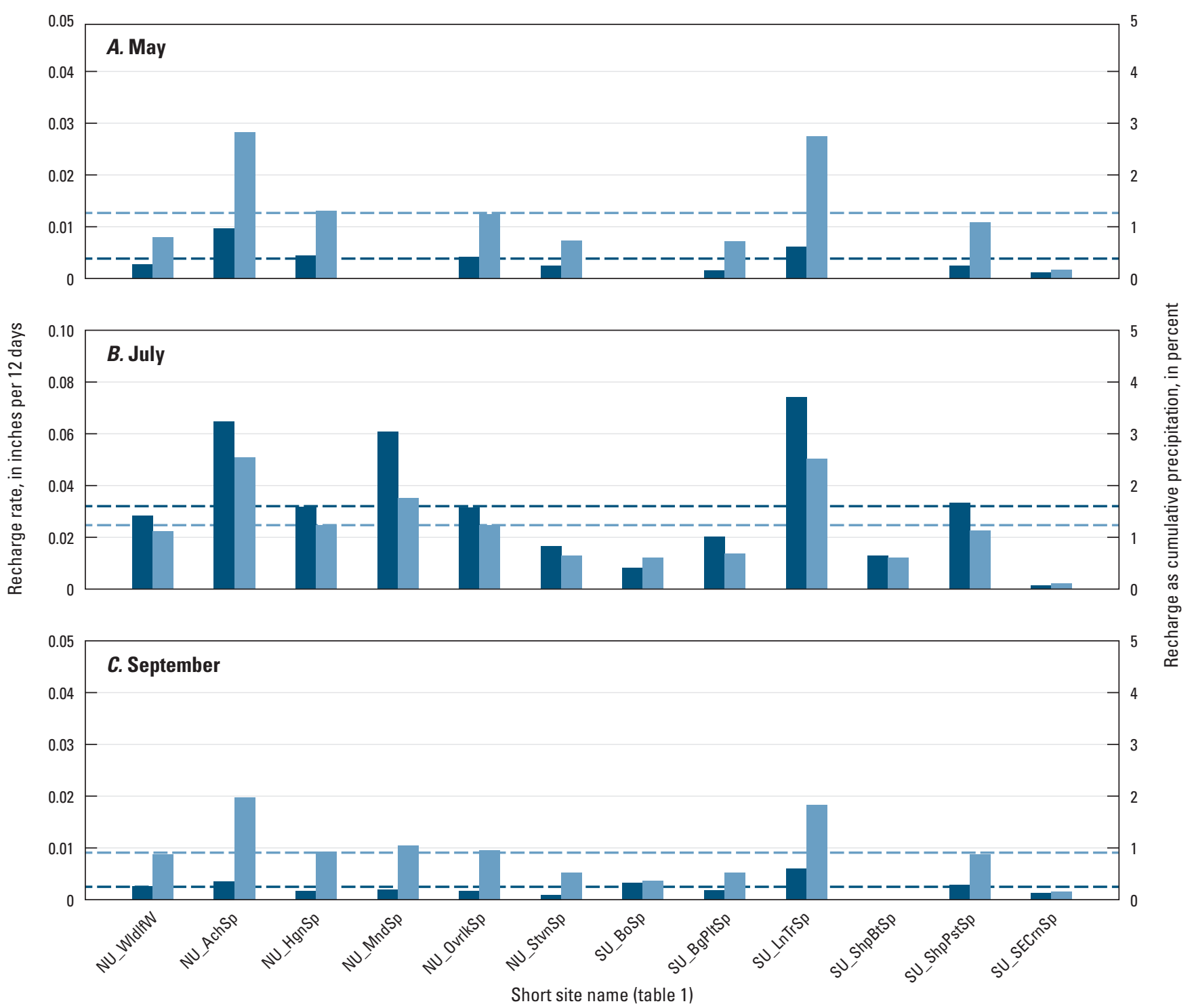

EXPLANATION

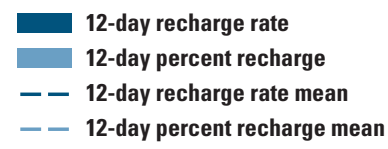

Figure 10. The 12-day recharge rate and 12-day percent recharge estimates from the chloride mass-balance method for springs and the Wildlife Well (NU_WIdIfW) in A, May 2018; B, July 2018; and C, September 2018.

chloride. Waters from Big Plateau Spring (SU_BgPltSp), Boicourt Spring (SU_BoSp), and Sheep Butte Spring (SU_ShpBtSp) were similar to Southeast Corner Spring (SU_ SECrnSp) and also may have been influenced by evaporation while collecting in shallow pools.

Spring samples from the North Unit generally had higher 12-day recharge rates and 12-day percent recharge estimates than spring samples from the South Unit (table 4; fig. 10). The 12-day estimates were calculated using environmental data; therefore, environmental factors could be responsible for differences between the North and South Units of the park. Relevant environmental factors include (1) chloride concentration differences in precipitation events (spatially and temporally), (2) geologic differences, and (3) different evapotranspiration rates. The higher recharge rate estimates for the North Unit could be from overestimation of the chloride concentration of precipitation. The only available NADP site for chloride concentrations in precipitation was in the South Unit of the park, which likely does not reflect the actual chloride concentrations of precipitation in the North Unit of the 
park. The North and South Units share the same geologic units (Biek and Gonzalez, 2001), and it is unlikely that recharge differences are related to lithology; however, aquifers in the North Unit could have increased infiltration capacity from greater weathering, the presence of geologic structures (faults, folds, and joints), or flatter topography (less runoff to streams). The recharge differences between the North and South Units also could be from variable evapotranspiration. Different evapotranspiration rates from climatic factors (temperature, wind, and precipitation), soil conditions (soil moisture and soil permeability), and vegetation (type and amount) also could explain the differences in recharge and chloride concentrations between the North and South Units of the park.

Differences between 12-day recharge rate and 12-day percent recharge estimates during the study were analyzed to determine which months had a greater contribution to groundwater recharge. Spring samples from July 2018 generally had the highest 12-day recharge rate estimates (fig. 10; table 4), most likely because the 12-day sample period collected in early July 2018 received, on average, about 6.2 and 7.4 times more precipitation than the 12-day sample periods for May and September 2018, respectively (table 4). The 12-day percent recharge estimates for May 2018 were generally higher than July 2018 with less total precipitation (table 4; fig. 10). The higher 12-day percent recharge in May 2018 indicated greater infiltration, whereas June and early July 2018 experienced greater surface runoff. The greater infiltration in May 2018 was potentially from snowmelt in March and April filling land surface depressions, leading to a longer period of infiltration. Another possibility is saturated soils from precipitation events in May and June rejected precipitation during early July 2018, inducing greater surface runoff. Streamflow data from USGS streamgages 06337000 and 06336000 in the North and South Units of the park, respectively, indicate greater infiltration in May 2018 and greater surface runoff in July 2018 (U.S. Geological Survey, 2020). May 2018 experienced high streamflow from spring snowmelt but had little precipitation, whereas June and July 2018 also experienced high streamflow and received the most precipitation. September 2018 had the lowest 12-day recharge rate and 12-day percent recharge estimates (table 4; fig. 10). The low estimates were likely because September 2018 received, on average, 1.2 and 7.4 times less precipitation than May and July 2018, respectively, in the 12-day period before sampling.

\section{Site Groupings and Water Sources from Principal Component Analysis}

The PCA method was used to create a biplot of waterchemistry data collected for this study (fig. 11). The combined sum of principal components one and two explained 61.6 percent of the total variance in the dataset. Figure 11 shows the $\delta^{18} \mathrm{O}$ and $\delta^{2} \mathrm{H}$ variables display strong positive correlation and are largely responsible for variation and grouping along principal component axis one; both $\delta^{18} \mathrm{O}$ and $\delta^{2} \mathrm{H}$ loading lines have nearly the same magnitude (length of the line) and are in the same direction. The $\delta^{18} \mathrm{O}$ and $\delta^{2} \mathrm{H}$ variables were expected to contribute to groupings because stable isotope plots (figs. 7, 8, 9) showed strong positive linear correlation. The $\delta^{18} \mathrm{O}$ and $\delta^{2} \mathrm{H}$ variables showed no correlation with chloride and $\mathrm{pH}$ - indicated by the approximately 90 -degree angle between loading lines - and only slightly positive correlation with water temperature and specific conductance (fig. 11). Water temperature displayed the least correlation with other variables - indicated by water temperature's loading line at a nearly 90 -degree angle from other variables (fig. 11). The water temperature for springs and streams varied because they were subjected to changes in air temperature that occurred monthly (May, July, and September), daily (hot days or cold days), and hourly (cool mornings and hot afternoons). Figure 11 also shows $\mathrm{pH}$ and chloride had strong positive correlation and were responsible for most of the variation along principal component axis two. Specific conductance displayed negative correlation with $\mathrm{pH}$ and chloride, indicated by the nearly 180-degree angle between loading lines, and had negative loading on principal component two, shown by the loading line plotting below zero on the $y$-axis. The positive and negative correlations between the $\mathrm{pH}$, chloride, and specific conductance variables were not evident from scatter plots of the three variables. The scattering of high and low chloride and specific conductance values for springs and streams likely was influenced by evaporation, similar to water temperature, from changes in air temperature that occurred monthly, daily, and hourly.

The plotting positions of sample sites in the PCA biplot show groupings and relations among sites (fig. 11). Surface water sites and some springs that plot in quadrant I and the upper part of quadrant IV have greater water temperature and $\delta^{18} \mathrm{O}$ and $\delta^{2} \mathrm{H}$ values than other sample sites. Samples from Fox Hills-lower Hell Creek aquifer wells grouped tightly in the upper part of quadrant II, which indicated that they had greater chloride concentrations and $\mathrm{pH}$ values and lesser $\delta^{18} \mathrm{O}$ and $\delta^{2} \mathrm{H}$ values. Samples from upper Fort Union aquifer wells plotted in the lower part of quadrant II and the upper part of quadrant III, which indicated chloride concentrations and $\mathrm{pH}$ values are lower in the upper Fort Union aquifer than the Fox Hills-lower Hell Creek aquifer. McMahon and others (2015) and Eldridge and Medler (2020) observed similar chloride and pH patterns for the upper Fort Union and Fox Hills-lower Hell Creek aquifers. The greater chloride and $\mathrm{pH}$ values for Fox Hills-lower Hell Creek aquifer indicate a long residence time with water quality affected by aquifer materials. Samples from the upper Fort Union aquifer wells had the lowest $\delta^{18} \mathrm{O}$ and $\delta^{2} \mathrm{H}$ values, indicated by samples plotting opposite and furthest from the $\delta^{18} \mathrm{O}$ and $\delta^{2} \mathrm{H}$ loading lines. The depleted stable isotopic composition of the upper Fort Union aquifer indicates that it receives recharge mostly from snowmelt and heavy rainfall. Samples from springs were generally scattered, but most plotted in the middle right part of quadrant III and the upper and middle left parts of quadrant IV, indicating that springs had the lowest temperatures, $\mathrm{pH}$ values, chloride concentrations, and 


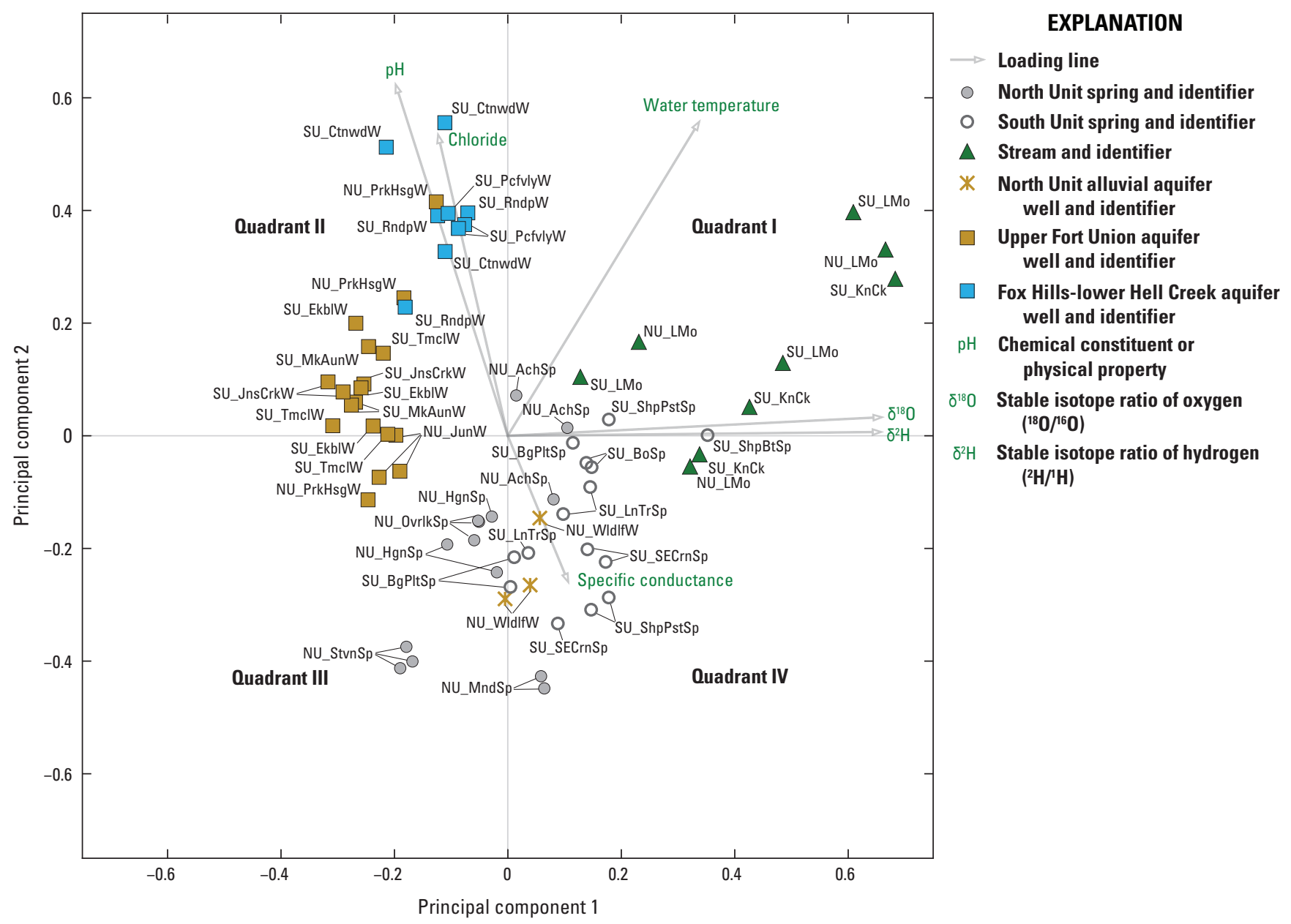

Figure 11. Principal component analysis biplot of water-chemistry data with loading lines for each variable label used in the analysis.

intermediate $\delta^{18} \mathrm{O}$ and $\delta^{2} \mathrm{H}$ values. The intermediate values of most springs indicate mixing of infiltrated precipitation and groundwater from the upper Fort Union aquifer.

The PCA results displayed noticeable groupings that aided in determining water sources for springs. Groundwater samples from wells completed in the Fox Hills-lower Hell Creek and upper Fort Union aquifers formed two distinct groups. The grouping and isolation of the Fox Hills-lower Hell Creek aquifer samples in quadrant II (fig. 11) indicated springs and streams were not sourced from the Fox Hillslower Hell Creek aquifer. The upper Fort Union aquifer also was isolated but Overlook Spring (NU_OvrlkSp) and Hagan Spring (NU_HgnSp) plotted near upper Fort Union aquifer samples in quadrant III (fig. 11), indicating that their waters were mixed more with upper Fort Union aquifer water more than other springs. Springs likely sourced from precipitation, also plotting close to stream samples, included Sheep Butte Spring (SU_ShpBtSp), Sheep Pasture Spring (SU_ShpPstSp), Boicourt Spring (SU_BoSp), and Achenbach Spring (NU_ AchSp; fig. 11).

\section{Cluster Assignments and Water Sources from Cluster Analysis}

The $k$-means procedure was applied to the PCA results of water-chemistry data to statistically determine similarities by grouping sampling sites. Sampling sites were grouped into five categories based on cluster assignments from the $k$-means procedure (fig. 12; table 5). Groups one and two included stream samples and some spring samples. Group two largely contained South Unit springs, and one North Unit spring (Achenbach Spring; NU_AchSp). Group three consisted of well samples from the Fox Hills-lower Hell Creek aquifer. Group four consisted of samples from wells completed in the upper Fort Union aquifer. Group five consisted of mostly North Unit springs known to be contact springs and flowing artesian springs with water chemistry akin to the upper Fort Union aquifer wells and shallow alluvial wells. Group five also contained some South Unit springs that plotted close to group two.

The $k$-means procedure grouped samples into clusters sharing similar physical property, chemical constituent, and stable isotope values that were used to identify whether spring 


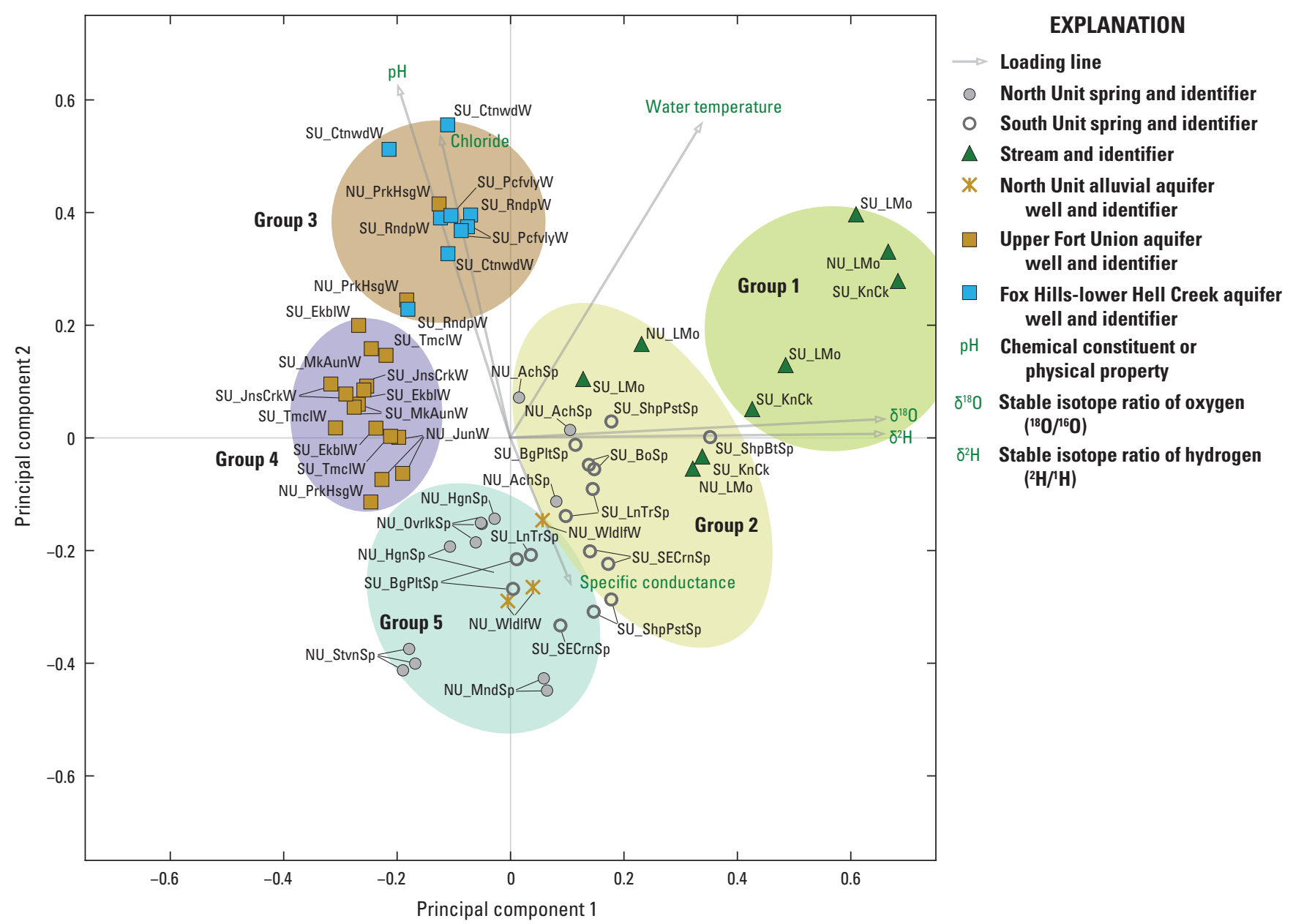

Figure 12. The $k$-means procedure applied to the principal component analysis biplot in figure 11 of water-chemistry data with colors symbolizing the five cluster assignment groups.

water was mostly from recently infiltrated precipitation or mixed with groundwater from the upper Fort Union aquifer. Stream samples in figure 12 were used as a proxy for precipitation because rain collector samples were not plotted. Samples in group five that plotted close to group four, upper Fort Union aquifer samples, were inferred to have greater contributions from groundwater than precipitation (fig. 12). Spring samples in group two- and some spring samples from group five- - were inferred to have greater contributions of precipitation because they plotted close to group one surface water samples (fig. 12). Although some springs had greater contributions from groundwater or surface water, PCA and cluster analysis results indicated that water from springs were a mixture of two or more sources, and varied May-September 2018.

Some samples from the same spring, such as Sheep Pasture Spring (SU_ShpPstSp), Big Plateau Spring (SU_ BgPltSp), and Southeast Corner Spring (SU_SECrnSp), were scattered depending on the collection date. The scattering likely was related to the elapsed time between precipitation events and sample collection. After precipitation events, spring samples exhibiting scattering plotted near group one (surface waters); however, samples collected 2 or more weeks after precipitation events plotted closer to group five (fig. 12). The scattering of spring samples in figure 12 indicated that precipication contributed most of the water sourced to springs during wet conditions; conversely, groundwater contributed more water to springs during dry conditions. Figures $7-9$ show that spring samples grouped closer toward precipitation and surface water during the wettest month (July 2018) and toward groundwater during dryer months (May and September 2018).

Some springs, such as Stevens Spring (NU_StvSp), Overlook Spring (NU_OvrlkSp), and Mandal Spring (NU_ MndSp), clustered together for all collection dates. Springs that were consistently part of group five exhibited tight grouping for all sample dates. Comparatively, springs that were split between groups 2 and 5 exhibited a wide range of scattering (fig. 12). Some springs that consistently plotted together grouped closer to upper Fort Union aquifer samples and were less affected by precipitation events, regardless of wet and dry conditions. These springs likely have greater contributions from either a semiconfined or confined aquifer, where 
Table 5. Summary of cluster analysis results listing groups, sampling site names, sampling site short names, and categories from the $k$-means clustering procedure applied to principal component analysis results.

[NU, North Unit; SU, South Unit]

\begin{tabular}{|c|c|c|c|}
\hline Group number & Short name (table 3) & $\begin{array}{l}\text { Number of samples from the } \\
\text { site in the cluster }\end{array}$ & Category1 \\
\hline \multirow[t]{3}{*}{1} & NU_LMo & 1 & Surface water \\
\hline & SU_LMo & 2 & \\
\hline & $\mathrm{SU} \_\mathrm{KnCk}$ & 2 & \\
\hline \multirow[t]{10}{*}{2} & NU_LMo & 2 & Springs and surface water \\
\hline & SU_LMo & 1 & \\
\hline & SU_KnCk & 1 & \\
\hline & NU_AchSp & 3 & \\
\hline & SU_BgPltSp & 1 & \\
\hline & SU_BoSp & 2 & \\
\hline & SU_LnTrSp & 2 & \\
\hline & SU_ShpBtSp & 1 & \\
\hline & SU_ShpPstSp & 2 & \\
\hline & SU_SECrnSp & 2 & \\
\hline \multirow[t]{4}{*}{3} & NU_PrkHsgW & 2 & Fox Hills-lower Hell Creek aquife \\
\hline & SU_CtnwdW & 3 & \\
\hline & SU_PcfvlyW & 3 & \\
\hline & SU_RndpW & 3 & \\
\hline \multirow[t]{6}{*}{4} & NU_PrkHsgW & 1 & Upper Fort Union aquifer \\
\hline & NU_JunW & 3 & \\
\hline & SU_JnsCrkW & 3 & \\
\hline & SU_MkAunW & 3 & \\
\hline & SU_EkblW & 3 & \\
\hline & SU_TmclW & 3 & \\
\hline \multirow[t]{9}{*}{5} & NU_WldlfW & 3 & Springs \\
\hline & NU_StvnSp & 3 & \\
\hline & NU_HgnSp & 3 & \\
\hline & NU_OvrlkSp & 3 & \\
\hline & NU_MndSp & 2 & \\
\hline & SU_BgPltSp & 2 & \\
\hline & SU_LnTrSp & 1 & \\
\hline & SU_ShpPstSp & 1 & \\
\hline & SU_SECrnSp & 1 & \\
\hline
\end{tabular}

1The category type was assigned from the dominant type of site observed in each group.

precipitation is infiltrated slowly at distant recharge areas. Additionally, figures 7-9 show spring samples that group near groundwater samples did not plot toward precipitation or surface water during any of the collection dates.

\section{Groundwater and Precipitation Contributions from End Member Mixing Analysis}

EMMA was used to estimate percent contributions from the upper Fort Union aquifer and precipitation to mixed samples from springs and one alluvial well using stable isotope plots. Figure 13 shows the mean percent contributions of upper Fort Union aquifer groundwater and precipitation for 


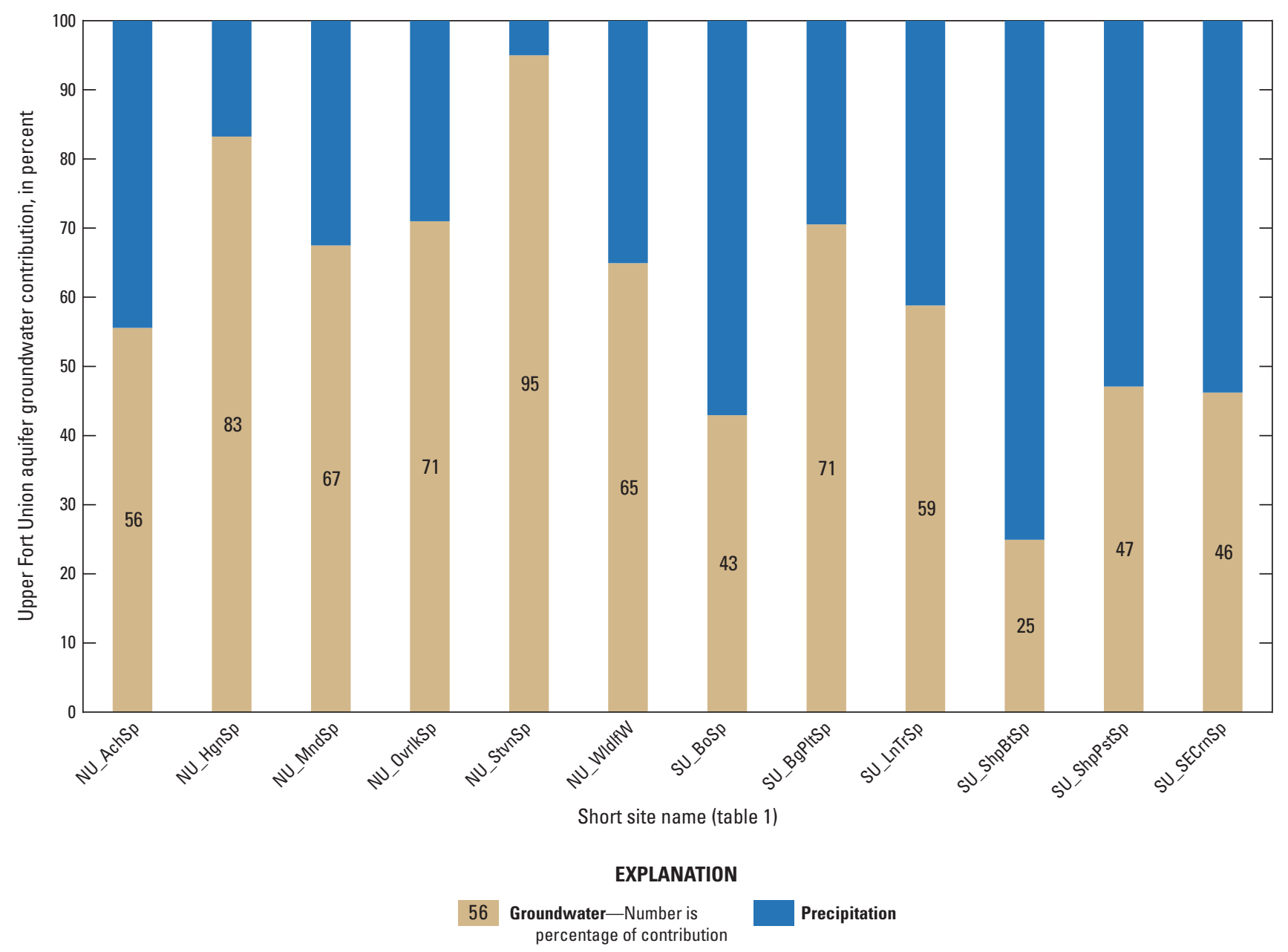

Figure 13. End member mixing analysis results for samples from springs and the Wildlife well expressed as mean percentages of upper Fort Union aquifer groundwater and precipitation.

each spring and the Wildlife well (NU_WldlfW). Springs in the North Unit generally had greater mean percent contributions of upper Fort Union aquifer groundwater than springs in the South Unit (fig. 13). Springs with the highest percent contribution of upper Fort Union aquifer groundwater were Stevens Spring (NU_StvnSp; 95 percent), Hagan Spring (NU_HgnSp; 83 percent), Overlook Spring (NU_OvrlkSp; 71 percent), and Big Plateau Spring (SU_BgPltSp; 71 percent). Springs with the lowest percent contributions of upper Fort Union aquifer groundwater, and therefore the highest percent contribution from precipitation, were Sheep Butte Spring (SU_ShpBtSp; 25 percent) and Boicourt Spring (SU_BoSp; 43 percent). The remaining springs had percent contributions of upper Fort Union aquifer groundwater between 46 and 65 percent (fig. 13).

The percent contribution from the upper Fort Union aquifer and precipitation varied between May, July, and September 2018. Figure 14 shows percent contribution from upper Fort Union aquifer for sites in May, July, and September 2018. The percent contribution of upper Fort Union aquifer generally decreased from relatively higher values in May 2018 to lower values in September 2018 (fig. 14); however, the percent contribution varied by less than 10 percent for most springs. Springs that showed the greatest change from May 2018 to September 2018 were Boicourt Spring (SU_BoSP; no sample collected in May 2018) and Sheep Butte Spring (SU_ShpBtSp).

EMMA results and spring types from figure 3 were used to identify the type of aquifer supplying springs based on percent contributions of groundwater and precipitation. Springs with the lowest percent contributions of upper Fort Union aquifer groundwater likely sourced water from infiltrating precipitation, recharging shallow unconfined aquifers above confining beds (lignite, shale, clay; upper contact springs in filtration or fig. 3). Springs with the highest percent contributions of upper Fort Union aquifer groundwater likely were sourced from semiconfined or confined aquifers, which recharge slowly by infiltrating precipitation over large areas and long time periods (lower contact springs in fig. 3). Springs with mixed contributions (percent contributions between 46 and 65 percent) could be sourced from semiconfined aquifers with discontinuous confining beds (lignite, shale, 


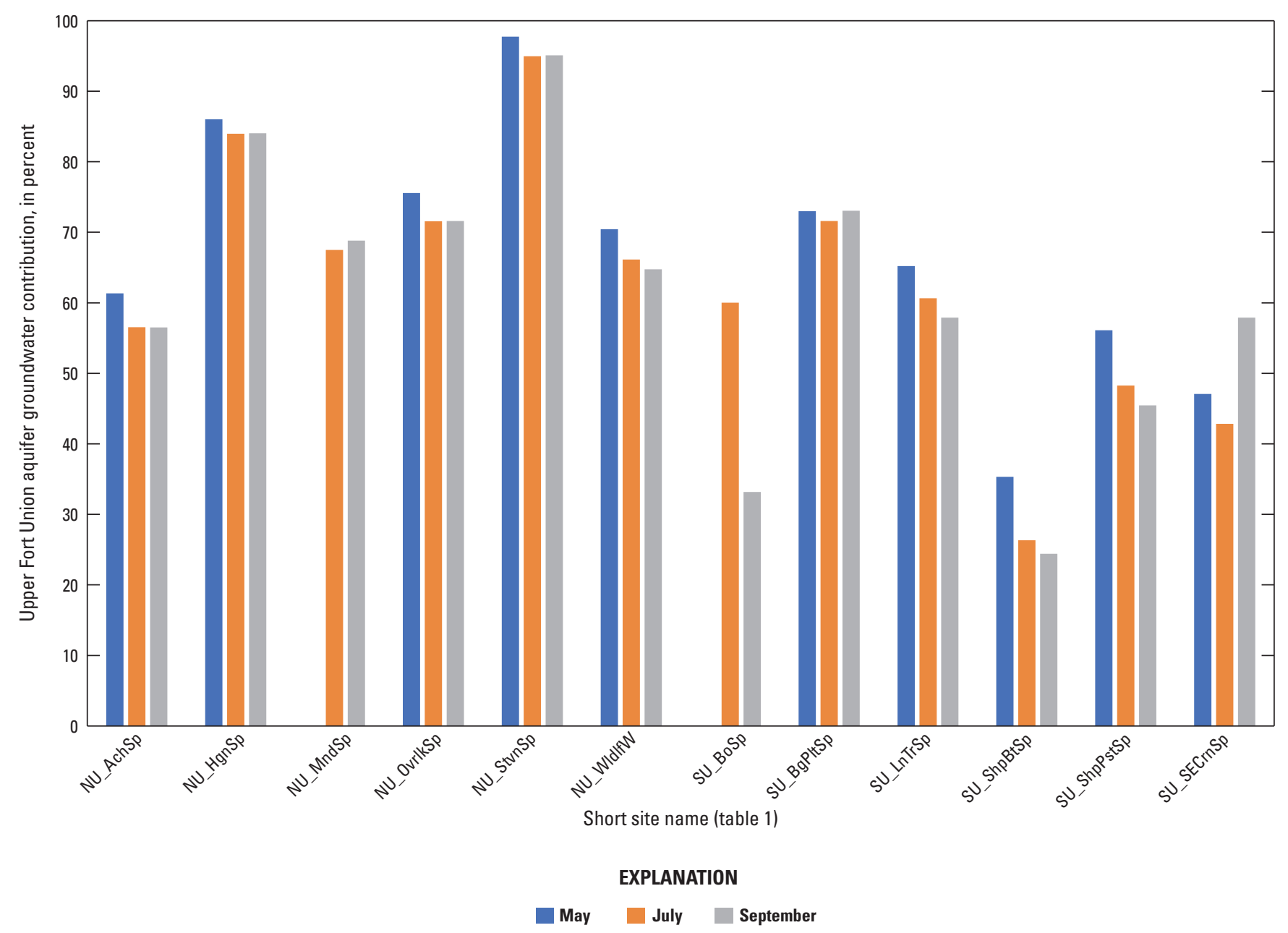

Figure 14. End member mixing analysis results for samples from springs and the Wildlife well expressed as percentages of upper Fort Union aquifer groundwater by month.

clay), recharged by infiltrated precipitation mixing with upper Fort Union aquifer groundwater (either upper or lower contact springs in fig. 3). The residence time of groundwater in semiconfined aquifers would be greater than shallow unconfined aquifers but less time than confined aquifers.

Springs with the lowest mean percent contributions from groundwater were Sheep Butte Spring (SU_ShpBtSp) and Boicourt Spring (SU_BoSp; fig. 13). Both springs are geographically closer to each other than to other springs and are in similar geologic settings. Sheep Butte Spring (SU_ShpBtSp) and Boicourt Spring (SU BoSp) are in the east-central part of the South Unit (fig. 4), and are in the Sentinel Butte Formation of the Fort Union Group (Biek and Gonzalez, 2001). Geologic maps of the study area (Biek and Gonzalez, 2001) do not show lignite or shale beds near the two springs, indicating both springs originate from a shallow unconfined aquifer and are infiltration-type springs.

Springs with the highest percent contributions from groundwater were Stevens Spring (NU_StvnSp), Hagan Spring (NU_HgnSp), Overlook Spring (NU_OvrlkSp), Big Plateau Spring (SU_BgPltSp), and Mandal Spring
(NU_MndSp; fig. 13). Four of the five springs are in the North Unit of the Park and are in the Sentinel Butte Formation of the Fort Union Group. Confining beds of lignite and bentonite clay have been mapped near the four springs (Biek and Gonzalez, 2001) indicating confined or semiconfined aquifers were supplying the springs. Big Plateau Spring (SU_BgPltSp), in the South Unit of the Park, is part of the Bullion Creek Formation of the Fort Union Group and has no nearby mapped confining beds (Biek and Gonzalez, 2001). Big Plateau Spring (SU_BgPltSp), however, was located on the east facing slope of a large butte capped by terrace gravels that could be obscuring confining beds.

Springs with nearly equal end member contributions from precipitation and upper Fort Union aquifer groundwater were Achenbach Spring (NU_AchSp), Lone Tree Spring (SU_LnTrSp), Sheep Pasture Spring (SU_ShpPstSp), and Southeast Corner Spring (SU_SECrnSp; fig. 13). Achenbach Spring (NU_AchSp), Sheep Pasture Spring (SU_ShpPstSp), and Southeast Corner Spring (SU_SECrnSp) are near or at the head of landslide deposits (Biek and Gonzalez, 2001). Landslides may have formed these springs by removing 
surface material, permitting groundwater from semiconfined or confined aquifers to flow at the land surface (fig. 3). These springs may also receive water from infiltrating precipitation recharging unconfined parts of the contributing aquifer, which would explain the mixture of upper Fort Union aquifer groundwater and precipitation (fig. 13). Lone Tree Spring (SU_LnTrSp) is not near a rotational slump or landslide, but it is near the contact of the Sentinel Butte and Bullion Creek Formations on the west facing slope of the same butte as Sheep Pasture Spring (Biek and Gonzalez, 2001). The nearly equal contributions from precipitation and upper Fort Union groundwater for Lone Tree Spring (SU_LnTrSp) could be from mixing of recently infiltrated precipitation with groundwater from a semiconfined or confined aquifer that provides water to the spring.

\section{Spring Types and Contributing Aquifers}

Water composition was used to determine the spring type and contributing aquifers for 11 springs in the North and South Units of Theodore Roosevelt National Park from analyses of water-chemistry data between May and September 2018 (table 6). Spring types assigned to the 11 sampled springs were: filtration, contact, and flowing artesian (fig. 3). Groundwater contributing to springs was from recently infiltrated precipitation in alluvial aquifers or mixed with upper Fort Union aquifer groundwater under unconfined, semiconfined, or confined conditions. The Fox Hills-lower Hell Creek aquifer did not contribute water to springs in the park because it is too deep to be hydrologically connected.

\section{North Unit Spring Types and Contributing Aquifers}

In the North Unit, Achenbach Spring (NU_AchSp) was classified as a filtration spring with water from an unconfined part of the upper Fort Union aquifer and infiltration of precipitation (table 6). Achenbach Spring (NU_AchSp) had the highest 12-day percent recharge from precipitation of all sampled springs, and end member contributions were nearly equal between precipitation and upper Fort Union aquifer water. The topography surrounding the spring - near the top of the Achenbach Hills in the Sentinel Butte Formation (fig. 4) is typical of a filtration spring (fig. 3).

Other North Unit springs - including Hagen Spring (NU_ HgnSp), Mandal Spring (NU_MndSp), and Stevens Spring (NU_StvnSp) - were classified as contact springs supplied by semiconfined parts of the upper Fort Union aquifer. The percentage of groundwater contributing to spring flow ranged from 67 percent (Mandal Spring, NU_MndSp) to 95 percent (Stevens Spring, NU_StvnSp), and the 12-day percent recharge ranged from 0.63 percent (Stevens Spring, NU StvnSp) to 1.40 percent (Mandal Spring, NU_MndSp) (fig. 13 and table 6). All three springs plotted in the spring group (group five) from PCA clustering (fig. 12), but Hagen Spring (NU_HgnSp) plotted close to the upper Fort Union aquifer. Topography and the location of mapped confining units (Biek and Gonzalez, 2001) place Hagen Spring (NU_HgnSp) and Stevens Spring (NU_StvnSp) as upper contact springs and Mandal Spring (NU_MndSp) as a lower contact spring. Stevens Spring (NU_StvnSp) likely has water sourced from a confined part of the upper Fort Union aquifer due to EMMA indicating a high percentage of upper Fort Union aquifer groundwater, low 12-day percent recharge, and PCA plotting position near upper Fort Union wells (fig. 12). Stevens Spring (NU_StvnSp) is at the top of a bluff (fig. 4) and the presence of a mapped confining bed (Biek and Gonzalez, 2001) indicates classification as an upper contact spring.

Overlook Spring (NU_OvrlkSp) at one time may have been a natural spring or seep but now is a developed spring that behaves like a flowing artesian well completed in a confined part of the upper Fort Union aquifer. Discharge at the site is from a 1.75-in. diameter vertical pipe of unknown length fixed in a concrete dish tank, and the hydraulic head from the spring is above land surface (Eldridge and Medler, 2020). Overlook Spring (NU_OvrlkSp) samples plotted close to wells completed in the upper Fort Union aquifer in PCA biplots (figs. 11, 12). Additionally, water-chemistry data from a National Park Service study in the 1980s (National Park Service, 1997), using PCA and cluster analysis, placed Overlook Spring (NU_OvrlkSp) with the upper Fort Union aquifer (appendix 1). EMMA revealed Overlook Spring had the third highest contribution from the upper Fort Union aquifer at 71 percent (fig. 13). Spring flow from Overlook Spring (NU_OvrlkSp) likely mixes with some precipitation, which accounts for the lower-than-expected percentage of upper Fort Union aquifer groundwater from EMMA.

\section{South Unit Spring Types and Contributing Aquifers}

In the South Unit, six springs were classified into two categories: filtration and contact springs (table 6; fig. 3). Boicourt Spring (SU_BoSp) and Sheep Butte Spring (SU_ShpBtSp) were classified as filtration springs, with water supplied by unconfined parts of the upper Fort Union aquifer and recently infiltrated precipitation. Both springs have relatively high 12-day percent recharge values compared to other South Unit springs - 0.39 percent for Sheep Butte Spring (SU_ShpBtSp) and 0.17 percent for Boicourt Spring (SU_BoSp; table 4). Additionally, both springs had the lowest percentages of upper Fort Union aquifer groundwater, calculated from EMMA, of South Unit springs with 43 percent for Boicourt Spring (SU_ BoSp) and 25 percent for Sheep Butte Spring (SU_ShpBtSp) (fig. 13). Both springs plotted in the spring group nearest stream samples (group two) in PCA and cluster analysis (figs. $11,12)$. Both springs also were geographically proximal and were positioned on hillslopes in the Sentinel Butte Formation (fig. 4; Biek and Gonzalez, 2001). 
Table 6. Summary of multivariate statistical analyses results with geologic setting, spring, type, and aquifer type for springs in the North and South Units of Theodore Roosevelt National Park.

[USGS, U.S. Geological Survey; CMB, chloride mass balance; PCA, principal component analysis; NPS, National Park Service]

\begin{tabular}{|c|c|c|c|c|c|c|c|c|}
\hline USGS site number1 & USGS site name ${ }^{1}$ & $\begin{array}{c}\text { CMB mean } \\
\text { 12-day recharge } \\
\text { from } \\
\text { precipitation } \\
\text { (\%; table 4) }\end{array}$ & $\begin{array}{l}\text { PCA and cluster } \\
\text { analysis with } 2018 \\
\text { study data (table 5) }\end{array}$ & $\begin{array}{l}\text { PCA and cluster } \\
\text { analysis with NPS } \\
\text { chemical data } \\
\text { 1984-88 (table 1.1) }\end{array}$ & $\begin{array}{l}\text { End member } \\
\text { mixing analysis- } \\
\text { Mean percent } \\
\text { groundwater } \\
\text { (fig. 13) }\end{array}$ & $\begin{array}{l}\text { Geologic formation } \\
\text { (Biek and Gonzalez, } \\
\text { 2001; fig. 2) }\end{array}$ & Spring type & Aquifer type \\
\hline \multicolumn{9}{|c|}{ North park unit } \\
\hline 473432103242801 & $\begin{array}{l}\text { Achenbach } \\
\text { Spring }\end{array}$ & 2.44 & $\begin{array}{l}\text { Springs and surface } \\
\text { water }\end{array}$ & $\begin{array}{l}\text { Springs and surface } \\
\text { water }\end{array}$ & 56 & Sentinel Butte & Filtration & $\begin{array}{r}\text { Unconfined aquifer } \\
\text { and precipitation }\end{array}$ \\
\hline 473644103181901 & Hagen Spring & 1.15 & $\begin{array}{l}\text { Springs (plots close to } \\
\text { upper Fort Union) }\end{array}$ & $\begin{array}{l}\text { Springs and surface } \\
\text { water }\end{array}$ & 83 & $\begin{array}{l}\text { Sentinel Butte } \\
\quad \text { (upper contact) }\end{array}$ & Upper contact & $\begin{array}{l}\text { Semiconfined } \\
\text { aquifer }\end{array}$ \\
\hline 473509103265101 & $\begin{array}{c}\text { 147-100-05 } \\
\text { (Mandal } \\
\text { Spring) }\end{array}$ & 1.40 & Springs & Springs and seeps & 67 & $\begin{array}{l}\text { Sentinel Butte } \\
\quad \text { (lower contact) }\end{array}$ & $\begin{array}{l}\text { Lower con- } \\
\text { tact }\end{array}$ & $\begin{array}{l}\text { Semiconfined } \\
\text { aquifer }\end{array}$ \\
\hline 473627103261601 & Overlook Spring & 1.14 & $\begin{array}{l}\text { Springs (plots close to } \\
\text { upper Fort Union) }\end{array}$ & $\begin{array}{l}\text { upper Fort Union } \\
\text { aquifer }\end{array}$ & 71 & Sentinel Butte & $\begin{array}{l}\text { Flowing arte- } \\
\text { sian (well) }\end{array}$ & Confined aquifer \\
\hline 473701103251401 & Stevens Spring & 0.63 & Springs & $\begin{array}{l}\text { Springs and surface } \\
\text { water }\end{array}$ & 95 & $\begin{array}{l}\text { Sentinel Butte } \\
\text { (upper contact) }\end{array}$ & Upper contact & $\begin{array}{l}\text { Semiconfined } \\
\text { aquifer }\end{array}$ \\
\hline \multicolumn{9}{|c|}{ South park unit } \\
\hline 465807103235601 & Boicourt Spring & 0.49 & $\begin{array}{l}\text { Springs and surface } \\
\text { water }\end{array}$ & $\begin{array}{l}\text { Springs and surface } \\
\text { water }\end{array}$ & 43 & $\begin{array}{l}\text { Sentinel Butte } \\
\text { (landslide) }\end{array}$ & Filtration & $\begin{array}{r}\text { Unconfined aquifer } \\
\text { and precipitation }\end{array}$ \\
\hline 465809103302201 & $\begin{array}{l}\text { Big Plateau } \\
\text { Spring }\end{array}$ & 0.24 & Springs & Springs and seeps & 71 & $\begin{array}{l}\text { Bullion Creek } \\
\text { and alluvium } \\
\text { beneath terrace } \\
\text { deposits (upper } \\
\text { contact) }\end{array}$ & Upper contact & $\begin{array}{l}\text { Semiconfined } \\
\text { aquifer }\end{array}$ \\
\hline 465856103334401 & $\begin{array}{l}\text { Lone Tree } \\
\text { Spring }\end{array}$ & 0.87 & Springs & $\begin{array}{l}\text { Springs and surface } \\
\text { water }\end{array}$ & 59 & $\begin{array}{l}\text { Sentinel Butte and } \\
\text { Bullion Creek } \\
\text { (upper contact) }\end{array}$ & Upper contact & $\begin{array}{l}\text { Semiconfined } \\
\text { aquifer }\end{array}$ \\
\hline 465726103224301 & $\begin{array}{l}\text { Sheep Butte } \\
\text { Spring }\end{array}$ & 0.39 & $\begin{array}{l}\text { Springs and surface } \\
\text { water }\end{array}$ & $\begin{array}{l}\text { Springs and surface } \\
\text { water }\end{array}$ & 25 & Sentinel Butte & Filtration & $\begin{array}{l}\text { Unconfined aquifer } \\
\text { and precipitation }\end{array}$ \\
\hline 465909103320401 & $\begin{array}{l}\text { Sheep Pasture } \\
\text { Spring }\end{array}$ & 0.39 & $\begin{array}{l}\text { Springs and surface } \\
\text { water }\end{array}$ & $\begin{array}{l}\text { Springs and surface } \\
\text { water }\end{array}$ & 47 & $\begin{array}{l}\text { Sentinel Butte and } \\
\text { Bullion Creek } \\
\text { (upper contact) }\end{array}$ & Upper contact & $\begin{array}{l}\text { Semiconfined } \\
\text { aquifer }\end{array}$ \\
\hline 465350103192901 & $\begin{array}{l}\text { Southeast } \\
\quad \text { Corner Spring }\end{array}$ & 0.04 & $\begin{array}{l}\text { Springs and surface } \\
\text { water }\end{array}$ & $\begin{array}{l}\text { Surface water and } \\
\text { springs }\end{array}$ & 46 & $\begin{array}{l}\text { Sentinel Butte and } \\
\text { landslide (upper } \\
\text { contact) }\end{array}$ & Upper contact & $\begin{array}{l}\text { Semiconfined } \\
\text { aquifer }\end{array}$ \\
\hline
\end{tabular}

1U.S. Geological Survey (2020). 
The four remaining springs in the South Unit were classified as contact springs (table 6). Topography and the location of mapped confining units (Biek and Gonzalez, 2001) place Big Plateau (SU_BgPltSp), Lone Tree Spring (SU_LnTrSp), Sheep Pasture Spring (SU_ShpPstSp), and Southeast Corner Spring (SU_SECrnSp) as upper contact springs. Big Plateau Spring (SU_BgPltSp) receives water from a semiconfined part of the upper Fort Union aquifer - indicated by 71 percent of its water sourced from groundwater (fig. 13) - and PCA clustering placed two of its three samples in the spring group closest to upper Fort Union aquifer (fig. 12). Similarly, Lone Tree Spring (SU_LnTrSp) receives water from a semiconfined aquifer but had less groundwater contribution at 59 percent (fig. 13) and plotted with spring samples in the group closest to stream samples (group five in fig. 12). Lone Tree Spring (SU_LnTrSp) and Big Plateau Spring (SU_BgPltSp) are near geologic contacts on the top of bluffs (fig. 4; Biek and Gonzalez, 2001) and are sourced more from the upper Fort Union aquifer than infiltrated precipitation.

Sheep Pasture Spring (SU_ShpPstSp) and Southeast Corner Spring (SU_SECrnSp) were categorized as contact springs (table 6) with 47 and 46 percent, respectively, of their water from the upper Fort Union aquifer (fig. 13). Both springs likely receive water from recently infiltrated precipitation as they were grouped closest to stream samples in PCA clustering (group five in fig. 12) and are in valleys near geologic contacts or landslides (Biek and Gonzalez, 2001). Southeast Corner Spring (SU_SECrnSp) had the lowest 12-day percent recharge value and the highest chloride concentrations of all springs with values ranging from 31.7 to 55.1 milligrams per liter (table 3). The chloride concentrations in Southeast Corner Spring (SU_SECrnSp) samples could be affected by the surrounding geology but likely resulted from evaporation concentrating chloride in the sampled pools. The PCA biplot (fig. 12) shows that Southeast Corner Spring (SU_SECrnSp) is similar to streams, water from Wildlife well (NU_WldlfW), and other South Unit contact springs. Southeast Corner Spring (SU_SECrnSp) also showed the greatest stable isotope variability during the sampling period. In May 2018, the isotopic signature of Southeast Corner Spring (SU_SECrnSp) was similar to streams (fig. 7), whereas in July and September 2018 was similar to Wildlife well (NU_WldlfW) (figs. 8, 9). The seasonal change of isotopes indicates that Southeast Corner Spring (SU_SECrnSp) receives a part of its water from precipitation.

\section{General Conclusions}

This study produced a few general conclusions about spring hydrology in Theodore Roosevelt National Park. First, recharging of unconfined and alluvial aquifers may occur over a 12-day period after precipitation events. Water levels in a well, completed in an unconfined part of the upper Fort Union aquifer, peaked about 12-days after precipitation (fig. 6). Second, the highest 12-day percent recharge and percentage of groundwater values were from springs in the North Unit. North Unit spring sites may have been improved, constructed differently, or maintained differently than South Unit sites so that the spring waters from North Unit springs may be less affected by standing water or rain events than South Unit springs (Eldridge and Medler, 2020). Finally, recharge rates calculated by the CMB method varied seasonally. The variable recharge rates were likely due to variations in temperature, evapotranspiration, and other climatic factors that affected the chloride concentrations.

\section{Data and Method Limitations}

Several limitations affected the completeness of study conclusions. Data limitations restricted the ability of the study to compare samples across an entire year-no isotope samples were collected from winter precipitation events. Stable isotope data collected in the winter from snowfall and snowmelt could provide a more complete analysis of source waters for springs. Another data limitation was continuous measurements of recent spring discharge were not available. Continuous spring discharge measurements would allow for comparisons between precipitation events and changes in spring discharge. Additionally, spring water chemistry samples did not include basic cations, anions, and additional field properties. A more complete water-chemistry analysis of spring waters could improve PCA and result in improved categorization and grouping of springs. Furthermore, chloride concentrations of precipitation were not available because of rain collector limitations. Another limitation was that sampling occurred within a single year and may not reflect hydrologic conditions that can vary from variable climatic conditions seasonally and annually. The recharge areas for filtration and contact springs near the margins of Theodore Roosevelt National Park could be within or outside park boundaries; however, additional data collection with greater spatial coverage is required to determine recharge areas.

Method limitations included assumptions necessary to complete analysis. Assumptions for both stable isotope and CMB methods were that samples were not affected by evaporative loss and, in the case of $\mathrm{CMB}$, the mass flux of chloride was static. An additional assumption was spring water was not in contact with marine sedimentary rocks, which would affect the chloride concentration of samples. Although geologic maps of the study area validate this assumption, it cannot be verified. Another assumption was that chloride concentrations for NADP site ND00, in the South Unit (fig. 4), adequately represented the precipitation chloride concentrations for both units in Theodore Roosevelt National Park. However, the park units are about $50 \mathrm{mi}$ apart, and precipitation events were not the same for both units (table 3 ). Collecting chloride concentration data for precipitation in the North and South Units of the park could provide more accurate chloride concentrations and validate data collected from one park unit. Finally, the 
12-day recharge assumption used for CMB calculations was estimated from data collected and recorded outside the park boundaries at only one well. Despite this limitation, CMB calculations are valid for comparing recharge rates among springs, but the calculated recharge rate may be inaccurate.

\section{Summary}

Water resources in Theodore Roosevelt National Park, North Dakota, support wildlife, visitors, and staff, and play a vital role in supporting the native ecology of the park. The National Park Service has concerns regarding water availability and possible sources of groundwater contamination in Theodore Roosevelt National Park. The U.S. Geological Survey, in cooperation with the National Park Service, conducted a study in 2018 and 2019 to address these concerns. The goal of the study was to improve hydrologic knowledge and determine the water composition of 11 seeps and springs in the park by collecting water-chemistry data at springs, streams, wells, and rain collectors.

Theodore Roosevelt National Park is in the southwestern part of North Dakota, in McKenzie and Billings Counties, and consists of three separate units: the North Unit, Elkhorn Ranch Unit, and the South Unit. Geologic maps show geologic exposures in the North and South Units of the park are upper Fort Union aquifer materials from the Sentinel Butte and Bullion Creek Formations. Additionally, low-permeability beds of bentonite, clinker, and lignite in the Sentinel Butte and Bullion Creek Formations were mapped in both units of the park. The presence of permeable and impermeable geologic formations, combined with steep topography, provide ideal conditions for spring and seep formation.

In Theodore Roosevelt National Park, the type of spring or seep can be identified by its contributing aquifer, geologic setting, and flow characteristics. Filtration springs and seeps (also called depression or dimple springs) discharge groundwater from unconfined aquifers near steep terrain, along the sides of bluffs, or at the base of hills and depressions, and receive water primarily from infiltrated precipitation that flows through the aquifer to the spring. Contact springs form along low-permeability units, such as the clinker deposits found in the Sentinel Butte Formation. The source of water for contact springs is unconfined aquifers, recharged by precipitation infiltrating downward until reaching a low-permeability unit and flowing along the low-permeability contact until reaching a point of discharge at the land surface. Artesian springs are formed by groundwater from confined aquifers that percolates upward through breaks or fissures in low permeability confining units.

Water samples were collected at 26 sites and included springs, streams, wells, and rain collectors in the North Unit and South Unit of Theodore Roosevelt National Park. Sites sampled in the North Unit were 5 springs, 1 stream, 2 wells, and 1 rain collector. Sites sampled in the South Unit were
6 springs, 2 streams, 8 wells, and 1 rain collector. Samples from springs, streams, and wells were collected in May, July, and September 2018. Samples from rain collectors were collected when enough daily precipitation accumulated in the collectors. Sampled precipitation events during the study period were in May, June, July, August, and September 2018. Physical properties of sampled water-temperature, $\mathrm{pH}$, and specific conductance-were measured in the field. Water samples were analyzed for stable isotopes of oxygen (oxygen-18, $\delta^{18 \mathrm{O}}$ ) and hydrogen (deuterium, $\delta^{2} \mathrm{H}$ ) and chloride concentration.

Recharge rates for aquifers supplying springs were determined using precipitation volume and chloride concentrations for a 12-day period before the sample collection date. Multivariate statistical analysis methods used on waterchemistry data included principal component analysis (PCA), cluster analysis, and end-member mixing analysis. PCA indicated that $\delta^{18} \mathrm{O}$ and $\delta^{2} \mathrm{H}$ variables exhibited a strong positive correlation and represented the greatest variation within the dataset. The $\delta^{18} \mathrm{O}$ and $\delta^{2} \mathrm{H}$ variables showed no correlation with chloride or $\mathrm{pH}$ and only slightly positive correlation with water temperature and specific conductance. Water temperature displayed the least correlation with other variables. PCA also indicated that $\mathrm{pH}$ and chloride had strong positive correlation and were responsible for most of the variation along principal component axis two.

The $k$-means procedure was applied to the PCA results of water-chemistry data to statistically determine similarities by grouping sampling sites. Sampling sites were grouped into five categories based on cluster assignments from the $k$-means procedure. Groups one and two included stream samples and some spring samples. Group two largely contained mostly South Unit springs and one North Unit spring (Achenbach Spring). Group three consisted of well samples from the Fox Hills-lower Hell Creek aquifer. Group four consisted of samples from wells completed in the upper Fort Union aquifer. Group five consisted of mostly North Unit springs known to be contact springs and flowing artesian springs with water chemistry akin to the upper Fort Union aquifer wells and shallow alluvial wells. Group five also contained some South Unit springs that plotted close to group two.

End-member mixing analysis was used to estimate percent contributions from the upper Fort Union aquifer and precipitation to mixed samples from springs and one alluvial well using stable isotope plots. Springs in the North Unit generally had greater mean percent contributions of upper Fort Union aquifer groundwater than springs in the South Unit. Springs with the highest percent contribution of upper Fort Union aquifer groundwater were Stevens Spring (95 percent), Hagan Spring (83 percent), Overlook Spring (71 percent), and Big Plateau Spring (71 percent). Springs with the lowest percent contributions of upper Fort Union aquifer groundwater, and therefore the highest percent contribution from precipitation, were Sheep Butte Spring (25 percent) and Boicourt Spring (43 percent). The remaining springs had percent contributions of upper Fort Union aquifer groundwater between 46 and 
65 percent. The percent contribution of the upper Fort Union aquifer groundwater and precipitation varied between May, July, and September 2018. The scattering of spring samples indicated precipitation contributed most of the water sourced to springs during wet conditions; conversely, groundwater contributed more water to springs during dry conditions.

Water composition was used to determine the spring type and contributing aquifers for 11 springs in the North and South Units of Theodore Roosevelt National Park from analyses of water-chemistry data between May and September 2018. In the North Unit, Achenbach Spring was classified as a filtration spring with water sources from an unconfined part of the upper Fort Union aquifer and infiltration of precipitation. Hagen Spring, Mandal Spring, and Stevens Spring were classified as contact springs supplied by semiconfined parts of the upper Fort Union aquifer. Overlook Spring at one time may have been a natural spring or seep but now is a developed spring that behaves like a flowing artesian well completed in a confined part of the upper Fort Union aquifer. In the South Unit, six springs were classified into two spring type categories: filtrations and contact springs. Boicourt Spring and Sheep Butte Spring were classified as filtration springs with water supplied by unconfined parts of the upper Fort Union aquifer and infiltrated precipitation. Big Plateau Spring, Lone Tree Spring, Sheep Pasture Spring, and Southeast Corner Spring were classified as contact springs that receive waters from a semiconfined part of the upper Fort Union aquifer.

\section{References Cited}

Amberg, S., Kilkus, K., Komp, M., Nadeau, A., Stark, K., Danielson, L., Gardner, S., Iverson, E., Norton, E., and Drazkowski, B., 2014, Theodore Roosevelt National ParkNatural resource condition assessment: Fort Collins, Colo., National Park Service, Natural Resource Report, NPS/ THRO/NRR-2014/776, 290 p., accessed December 2019 at https://irma.nps.gov/DataStore/DownloadFile/491476.

Anderholm, S.K., 1994, Ground-water recharge near Santa Fe, north-central New Mexico: U.S. Geological Survey WaterResources Investigations Report 94-4078, 68 p., accessed August 2020 at https://doi.org/10.3133/wri944078.

Anna, L.O., 1981, Ground-water resources of Billings, Golden Valley, and Slope Counties, North Dakota: North Dakota Geological Survey, North Dakota State Water Commission, County Ground-Water Studies 29, pt. III, 62 p.

Anna, L.O., Pollastro, R., and Gaswirth, S.B., 2013, Williston Basin Province-Stratigraphic and structural framework to a geologic assessment of undiscovered oil and gas resources: U.S. Geological Survey Digital Data Series DDS-69-W, chap. 2, 216 p. [Also available at https://pubs.usgs.gov/dds/dds-069/dds-069-w/.]
Biek, R.F., and Gonzalez, M.A., 2001, The geology of Theodore Roosevelt National Park-Billings and McKenzie Counties, North Dakota: North Dakota Geological Survey Miscellaneous Series No. 86, 74 p., accessed March 2020 at https://www.dmr.nd.gov/ndgs/Publication_List/pdf/ MISC\%20SERIES/MS-86\%20w.plates.pdf.

Blasch, K.W., and Bryson, J.R., 2007, Distinguishing sources of groundwater recharge using $\delta^{2} \mathrm{H}$ and $\delta^{18 \mathrm{O}}$ : Ground Water, v. 45, no. 3, p. 294-308, accessed March 2020 at https://doi.org/10.1111/j.1745-6584.2006.00289.x.

Bluemle, J.P., 1977, The face of North Dakota-The geologic story: North Dakota Geological Survey Educational Series 11, 73 p., accessed March 2020 at https://www.dmr.nd.gov/ndgs/documents/Publication_List/ pdf/EducationSeries/ED-11.pdf.

Brooks, L.E., and Mason, J.L., 2005, Hydrology and simulation of ground-water flow in Cedar Valley, Iron County, Utah: U.S. Geological Survey Scientific Investigations Report 2005-5170, 110 p., accessed August 2020 at https://doi.org/10.3133/sir20055170.

Bryan, K., 1919, Classification of springs: The Journal of Geology, v. 27, no. 7, p. 522-561, accessed December 4, 2019, at https://doi.org/10.1086/622677.

Celestino, A.E., Martinez Cruz, D.A., Otazo Sanchez, E.M., Reyes, F.G., and Soto, D.V., 2018, Groundwater quality assessment-An improved approach to $k$-means clustering, principal component analysis and spatial analysis-A case study: Water, v. 10, 21 p., accessed March 2020 at https://doi.org/10.3390/w10040437.

Christophersen, N., and Hooper, R.P., 1992, Multivariate analysis of stream water chemical data-The use of principal components analysis for the end-member mixing problem: Water Resources Research, v. 28, no. 1, p. 99-107, accessed May 2020 at https://doi.org/10.1029/91WR02518.

Christophersen, N., Neal, C., Hooper, R.P., Vogt, R.D., and Andersen, S., 1990, Modeling streamwater chemistry as a mixture of soilwater end-members - A step towards second-generation acidification models: Journal of Hydrology (Amsterdam), v. 116, no. 1-4, p. 307-320, accessed April 2020 at https://doi.org/10.1016/00221694(90)90130-P.

Clark, I., and Fritz, P., 1997, Environmental isotopes in hydrogeology: Boca Raton, CRC Press, 342 p.

Craig, H., 1961, Isotopic variations in meteoric waters: Science, v. 133 , no. 3465 , p. 1702-1703, accessed March 2020 at https://doi.org/10.1126/ science.133.3465.1702. 
Croft, M.G., 1985, Ground-water resources of McKenzie County, North Dakota: North Dakota State Water Commission, County Ground-Water Studies 37, pt. III, 57 p., accessed December 2019 at https://www.swc.nd.gov/ info_edu/reports_and_publications/county_groundwater_ studies/pdfs/McKenzie_Part_III.pdf.

Dansgaard, W., 1964, Stable isotopes in precipitation: Tellus, v. 16, no. 4, p. 436-537, accessed August 2020 at https://doi.org/10.3402/tellusa.v16i4.8993.

Davis, J.C., 2002, Statistics and data analysis in geology $3 d$ ed.: Hoboken, New Jersey, John Wiley and Sons, Inc., $638 \mathrm{p}$.

Dettinger, M.D., 1989, Reconnaissance estimates of natural recharge to desert basins in Nevada, U.S.A., by using chloride-balance calculations: Journal of Hydrology (Amsterdam), v. 106, no. 1-2, p. 55-78, accessed March 2020 at https://doi.org/10.1016/00221694(89)90166-2.

Eldridge, W.G., and Medler, C.J., 2020, Inventory and analysis of groundwater resources in Theodore Roosevelt National Park, North Dakota: Fort Collins, Colo., National Park Service, Natural Resource Report NPS/ TRHO/NRR - 2020/2124, accessed August 2020 at https://pubs.er.usgs.gov/publication/70210041.

Fishman, M.J., 1993, Methods of analysis by the U.S. Geological Survey National Water Quality Laboratory-Determination of inorganic and organic constituents in water and fluvial sediments: U.S. Geological Survey Open-File Report 93-125, 217 p., accessed August 2020 at https://doi.org/10.3133/ofr93125.

Fishman, M.J., and Friedman, L.C., 1989, Methods for determination of inorganic substances in water and fluvial sediments: U.S. Geological Survey Techniques of Water Resources Investigations, book 5, chap. A1, 545 p.

Frisbee, M.D., Phillips, F.M., White, A.F., Campbell, A.R., and Liu, F., 2013, Effect of source integration on the geochemical fluxes from springs: Applied Geochemistry, v. 28, p. 32-54, accessed April 2020 at https://doi.org/10.1016/ j.apgeochem.2012.08.028.

Garbarino, J.R., Kanagy, L.K., and Cree, M.E., 2006, Determination of elements in natural-water, biota, sediment and soil samples using collision/reaction cell inductively coupled plasma-mass spectrometry: U.S. Geological Survey Techniques and Methods, book 5, chap. B1, 88 p.

Gat, J.R., 1971, Comments on the stable isotope method in regional groundwater investigations: Water Resources Research, v. 7, no. 4, p. 980-993, accessed March 2020 at https://doi.org/10.1029/WR007i004p00980.
Gat, J.R., and Gonfiantini, R., 1981, Stable isotope hydrology-Deuterium and oxygen-18 in the water cycle: International Atomic Energy Agency Technical Report Series No. 210, 339 p., accessed April 2020 at https://inis.iaea.org/search/search.aspx?orig_q= RN:13677657.

Gates, J.B., Edmunds, W.M., Ma, J., and Scanlon, B.R., 2008, Estimating groundwater recharge in a cold desert environment in northern China using chloride: Hydrogeology Journal, v. 16, no. 5, p. 893-910. [Also available at https://doi.org/10.1007/s10040-007-0264-z.]

Gesch, D.B., 2007, The National Elevation Dataset, in Maune, D.F., ed., Digital elevation model technologies and applications-The DEM user's manual, 2d ed.: Bethesda, Md., American Society for Photogrammetry and Remote Sensing, p. 99-118.

Gesch, D.B., Oimoen, M.J., Greenlee, S.K., Nelson, C.A., Steuck, M.J., and Tyler, D.J., 2002, The National Elevation Dataset: Photogrammetric Engineering and Remote Sensing, v. 68, no. 1, p. 5-11.

Greene, E.A., 1997, Tracing recharge from sinking streams over spatial dimensions of kilometers in a karst aquifer: Ground Water, v. 35, no. 5, p. 898-904. [Also available at https://doi.org/10.1111/j.1745-6584.1997.tb00159.x.]

Griffin, E.R., and Friedman, J.M., 2017, Decreased runoff response to precipitation, Little Missouri River Basin, Northern Great Plains, USA: Journal of the American Water Resources Association, v. 53, no. 3, p. 576-592, accessed June 2020 at https://doi.org/10.1111/1752-1688.12517.

Healy, R.W., 2010, Estimating groundwater recharge: Cambridge University Press, 245 p. [Also available at https://doi.org/10.1017/CBO9780511780745.]

Helsel, D.R., Hirsch, R.M., Ryberg, K.R., Archfield, S.A., and Gilroy, E.J., 2020, Statistical methods in water resources: U.S. Geological Survey Techniques and Methods, book 4, chapter A3, 458 p. [Also available at https://doi.org/ $10.3133 / \mathrm{tm} 4 \mathrm{a} 3$.

Hooper, R.P., Christophersen, N., and Peters, N.E., 1990, Modeling streamwater chemistry as a mixture of soilwater end-members - An application to the Panola Mountain catchment, Georgia, USA: Journal of Hydrology (Amsterdam), v. 116, no. 1-4, p. 321-343, accessed April 2020 at https://doi.org/10.1016/00221694(90)90131-G.

Iierkley, J., Reetz, G.R., and Vanna-Miller, D., 1998, Water resources management plan, Theodore Roosevelt National Park: U.S. Environmental Protection Agency, Region VIII, $141 \mathrm{p}$. 
Jolliffe, I.T., 2002, Principal component analysis, 2d ed.: New York, Springer, $487 \mathrm{p}$.

Kanduč, T., Mori, N., Kocman, D., Stibilj, V., and Grassa, F., 2012, Hydrogeochemistry of alpine springs from North Slovenia-Insights from stable isotopes: Chemical Geology, v. 300-301, p. 40-54, accessed March 2020 at https://doi.org/10.1016/j.chemgeo.2012.01.012.

Kendall, C., and Caldwell, J.J., 1998, Isotope tracers in catchment hydrology: Amsterdam, Elsevier Science, 839 p.

Long, A.J., Ohms, M.J., and McKaskey, J.D.R.G., 2012, Groundwater flow, quality (2007-10), and mixing in the Wind Cave National Park area, South Dakota: U.S. Geological Survey Scientific Investigations Report 2011-5235, 50 p., accessed August 2020 at https://doi.org/ $10.3133 /$ sir20115235.

Long, A.J., Paces, J.B., and Eldridge, W.G., 2019. Multivariate analysis of hydrochemical data for Jewel Cave, Wind Cave, and surrounding areas: Fort Collins, Colo., National Park Service, Natural Resource Report NPS/JECA/NRR—2019/1883. accessed August 2020 at https://irma.nps.gov/DataStore/DownloadFile/620542.

Long, A.J., and Valder, J.F., 2011, Multivariate analyses with end-member mixing to characterize groundwater flow-Wind Cave and associated aquifers: Journal of Hydrology (Amsterdam), v. 409, no. 1-2, p. 315-327, accessed August 2020 at https://doi.org/10.1016/ j.jhydrol.2011.08.028.

Masoud, A.A., 2014, Groundwater quality assessment of the shallow aquifers west of the Nile Delta (Egypt) using multivariate statistical and geostatistical techniques: Journal of African Earth Sciences, v. 95, p. 123-137, accessed March 2020 at https://doi.org/10.1016/ j.jafrearsci.2014.03.006.

Matheney, R.K., and Gerla, P.J., 1996, Environmental isotopic evidence for the origins of ground and surface water in a prairie discharge wetland: Wetlands, v. 16, no. 2 , p. 109-120, accessed March 2020 at https://doi.org/ 10.1007/BF03160684.

McCoy, K.J., and Blanchard, P.J., 2008, Precipitation, groundwater hydrology, and recharge along the eastern slopes of the Sandia Mountains, Bernalillo County, New Mexico: U.S. Geological Survey Scientific Investigations Report 2008-5179, 34 p., accessed August 2020 at https://doi.org/ 10.3133/sir20085179.
McMahon, P.B., Caldwell, R.R., Galloway, J.M., Valder, J.F., and Hunt, A.G., 2015, Quality and age of shallow groundwater in the Bakken Formation production area, Williston Basin, Montana and North Dakota: Ground Water, v. 53, no. S1, p. 81-94. [Also available at https://doi.org/10.1111/ gwat.12296.]

Michelsen, N., van Geldern, R., Roßmann, Y., Bauer, I., Schulz, S., Barth, J.A.C., and Schüth, C., 2018, Comparison of precipitation collectors used in isotope hydrology: Chemical Geology, v. 488, p. 171-179. [Also available at https://doi.org/10.1016/j.chemgeo.2018.04.032.]

Mori, N., Kanduc, T., Opalicki Slabe, M., and Brancelj, A., 2015 , Groundwater drift as a tracer for identifying sources of spring discharge: Ground Water, v. 53, no. S1, no. S1, p. 123-132, accessed March 2020 at https://doi.org/10.1111/ gwat.12314.

Muir, K.S., and Coplen, T.B., 1981, Tracing ground-water movement by using the stable isotopes of oxygen and hydrogen, Upper Penitencia Creek Alluvial Fan, Santa Clara Valley, California: U.S. Geological Survey Water-Supply Paper 2075, 18 p., accessed August 2020 at https://doi.org/ 10.3133/wsp2075.

Murphy, E.C., Nordeng, S.H., Juenker, B.J., and Hoganson, J.W., 2009, North Dakota stratigraphic column: North Dakota Geological Survey Miscellaneous Series 91, accessed December 2019 at https://www.dmr.nd.gov/ndgs/ documents/Publication_List/pdf/Strat-column-NDGS(2009).pdf.

National Atmospheric Deposition Program [NADP], 2020, NTN site information: National Atmospheric Deposition Program, digital data, accessed March 2020 at http://nadp.slh.wisc.edu/data/sites/map/?net=NTN.

National Oceanic and Atmospheric Administration [NOAA], 2020, Climate Data Online: National Centers for Environmental Information, digital data, accessed March 2020 at https://www.ncdc.noaa.gov/cdo-web.

National Park Service, 1997, Baseline water quality data inventory and analysis - Theodore Roosevelt National Park: National Park Service, Technical Report NPS/NRWRD/ NRTR-97/100, 499 p.

National Park Service, 2011, Theodore Roosevelt National Park water-right docket no. 11-Springs and seeps: National Park Service Water-Right Docket No. 11, 34 p.

National Park Service, 2014, Theodore Roosevelt National Park natural resource condition assessment: U.S. Department of the Interior, Natural Resource Report 2014/776, 290 p. 
Naus, C.A., Driscoll, D.G., and Carter, J.M., 2001, Geochemistry of the Madison and Minnelusa aquifers in the Black Hills area, South Dakota: U.S. Geological Survey Water-Resources Investigations Report 01-4129, 123 p.

Neal, C., and Kirchner, J.W., 2000, Sodium and chloride levels in rainfall, mist, streamwater and groundwater at the Plynlimon catchments, mid-Wales-Inferences on hydrological and chemical controls: Hydrology and Earth System Sciences, v. 4, no. 2, p. 295-310, accessed March 2020 at https://doi.org/10.5194/hess-4-295-2000.

North Dakota State Water Commission, 2015, Ground/surface water data: North Dakota State Water Commission web page, accessed June 2020 at https://www.swc.nd.gov/info_ edu/map_data_resources/groundsurfacewater/.

Oehler, M., and Sexton, C., 2010, Man-made water developments in the South Unit of Theodore Roosevelt National Park-Technical summary of research project and management recommendations: Medora, N. Dak., National Park Service, $45 \mathrm{p}$.

Pollastro, R.M., Roberts, L.N.R., and Cooks, T.A., 2013, Geologic assessment of technically recoverable oil in the Devonian and Mississippian Bakken Formation: U.S. Geological Survey Digital Data Series DDS-69-W, chap. 5, 34 p. [Also available at https://pubs.usgs.gov/dds/ dds-069/dds-069-w/.]

Putnam, L.D., Hoogestraat, G.K., and Sawyer, J.F., 2008, Water-quality effects and characterization of indicators of onsite wastewater disposal systems in the east-central Black Hills area, South Dakota, 2006-08: U.S. Geological Survey Scientific Investigations Report 2008-5232, 115 p. [Also available at https://doi.org/10.3133/sir20085232.]

Rehm, B.W., Moran, S.R., and Groenewold, G.H., 1982, Natural groundwater recharge in an upland area of central North Dakota, U.S.A: Journal of Hydrology (Amsterdam), v. 59, no. 3-4, p. 293-314, accessed March 2020 at https://doi.org/10.1016/0022-1694(82)90093-2.

Révész, K., and Coplen, T.B., 2008a, Determination of the $\delta(180 / 160)$ of water-RSIL lab code 489, in Révész, K., and Coplen, T.B., eds., Methods of the Reston Stable Isotope Laboratory: U.S. Geological Survey Techniques and Methods, book 10, chap. C2, p. 28.

Révész, K., and Coplen, T.B., 2008b, Determination of the $\delta(2 \mathrm{H} / 1 \mathrm{H})$ of water-RSIL lab code 1574, in Révész, K., and Coplen, T.B., eds., Methods of the Reston Stable Isotope Laboratory: U.S. Geological Survey Techniques and Methods, book 10, chap. C1, p. 27.

Rossum, G. van, and Drake, F.L., Jr., 2011, The Python language reference manual: United Kingdom, Network Theory Limited, $150 \mathrm{p}$.
Rozanski, K., Araguas-Araguas, L., and Gonfiantini, R., 1993, Isotopic patterns in modern global precipitationClimate change in continental isotopic records: Geophysical Monograph, v. 78, p. 1-36, accessed March 2020 at https://doi.org/10.1029/GM078p0001.

Sandberg, C.A., 1962, Geology of the Williston Basin, North Dakota, Montana, and South Dakota, with reference to subsurface disposal of radioactive wastes: U.S. Geological Survey Trace Elements Investigations 809, 148 p. [Also available at https://doi.org/10.3133/tei809.]

Sando, S.K., Furlong, E.T., Gray, J.L., and Meyer, M.T., 2006, Occurrence of organic wastewater compounds in drinking water, wastewater effluent, and the Big Sioux River in or near Sioux Falls, South Dakota, 2001-2004: U.S. Geological Survey Scientific Investigations Report 2006-5118, 168 p. [Also available at https://doi.org/ $10.3133 /$ sir20065118.]

Simpson, H.E., and Riffenburg, H.B., 1929, Geology and ground-water resources of North Dakota, with a discussion of the chemical character of the water: U.S. Geological Survey Water-Supply Paper 598, 323 p. [Also available at https://doi.org/10.3133/wsp598.]

Stamm, J.F., and McBride, W.S., 2016, Sources of groundwater and characteristics of surface-water recharge at Bell, White, and Suwannee Springs, Florida: 2012-13: U.S. Geological Survey Open-File Report 2016-1190, 27 p. [Also available at https://doi.org/10.3133/ofr20161190.]

Sustainability of Semi-Arid Hydrology and Riparian Areas, 2020, Isotopes: Sustainability of Semi-Arid Hydrology and Riparian Areas web page, accessed April 2020 at http://web.sahra.arizona.edu/programs/isotopes/ oxygen.html.

Taylor, J.K., 1987, Quality assurance of chemical measurements: Chelsea, Mich., Lewis Publishers, 328 p.

Tian, C., Wang, L., Kaseke, K.F., and Bird, B.W., 2018, Stable isotope compositions $\left(\delta^{2} \mathrm{H}, \delta^{18} \mathrm{O}\right.$ and $\left.\delta^{17} \mathrm{O}\right)$ of rainfall and snowfall in the central United States: Scientific Reports, v. 8, no. 1, p. 6712-6727, accessed March 2020 at https://doi.org/10.1038/s41598-018-25102-7.

U.S. Geological Survey, 2004, Resources on isotopesPeriodic table-Hydrogen: U.S. Geological Survey web page, accessed April 2020 at https://wwwrcamnl.wr.usgs.gov/isoig/period/h_iig.html.

U.S. Geological Survey, 2019, Dictionary of water terms: U.S. Geological Survey web page, accessed December 2019 at https://www.usgs.gov/special-topic/water-science-school/ science/dictionary-water-terms?qt-science_center_objects= 0\#qt-science_center_objects. 
U.S. Geological Survey, 2020, USGS water data for the Nation: U.S. Geological Survey National Water Information System database, accessed March 2020 at https://doi.org/ 10.5066/F7P55KJN.

U.S. Geological Survey, variously dated, National field manual for the collection of water-quality data: U.S. Geological Survey Techniques of Water-Resources Investigations, book 9, chaps. A1-A10, accessed May 15, 2020, at https://www.usgs.gov/mission-areas/waterresources/science/national-field-manual-collection-waterquality-data-nfm?qt-science_center_objects=0\#qt-science center_objects.

Valder, J.F., Long, A.J., Davis, A.D., and Kenner, S.J., 2012, Multivariate statistical approach to estimate mixing proportions for unknown end members: Journal of Hydrology (Amsterdam), v. 460-461, p. 65-76, accessed March 2020 at https://doi.org/10.1016/j.jhydrol.2012.06.037.

Vogel, J.C., and Van Urk, H., 1975, Isotopic composition of groundwater in semi-arid regions of southern Africa: Journal of Hydrology (Amsterdam), v. 25, no. 1-2, p. 23-36, accessed March 2020 at https://doi.org/10.1016/ 0022-1694(75)90036-0.
Wood, W.W., 1999, Use and misuse of the chloride massbalance method in estimating ground-water recharge: Ground Water, v. 37, no. 1, p. 2-3, accessed March 2020 at https://doi.org/10.1111/j.1745-6584.1999.tb00949.x.

Wood, W.W., and Sanford, W.E., 1995, Chemical and isotopic methods for quantifying ground-water recharge in a regional, semiarid environment: Ground Water, v. 33, no. 3, p. 458-468, accessed March 2020 at https://doi.org/10.1111/ j.1745-6584.1995.tb00302.x.

Zdon, A., Davisson, M.L., and Love, A.H., 2018, Understanding the source of water for selected springs within Mojave Trails National Monument, California: Environmental Forensics, v. 19, no. 2, p. 99-111, accessed April 2020 at https://doi.org/10.1080/ 15275922.2018.1448909. 


\section{Appendix 1. Principal Component Analysis and Cluster Analysis with Water-Chemistry Data from a 1980s National Park Service Study in Theodore Roosevelt National Park}

Multivariate statistical methods were used on waterchemistry data collected at springs, streams, and wells in the North and South Units of Theodore Roosevelt National Park during the 1980s by the National Park Service (NPS, 1997). Principal component analysis (PCA) and the $k$-means procedure were used to elucidate relations among water-chemistry data and group samples into clusters. The physical properties and chemical constituents from the NPS (1997) dataset included $\mathrm{pH}$, specific conductance, total dissolved solids, turbidity, iron, manganese, calcium, magnesium, potassium, sodium, chloride, sulfate, bicarbonate, carbonate, nitrate, and fluoride. No samples were excluded from the PCA because all samples had the same number of variables (physical properties and chemical constituents). Physical properties and chemical constituents were normalized and standardized before performing PCA to ensure the distribution of the dataset was independent of measurement units (Davis, 2002). The $k$-means procedure was run 10 times at 300 iterations per run (a total of 3,000 iterations) on PCA results to group samples into clusters for interpretation.

The PCA method was used to create a biplot of the waterchemistry data. Figure 1.1 is a two-dimensional PCA biplot with samples plotted on principal component axes one and two. The combined sum of principal components one and two was 60.3 percent of the total variance in the dataset. Loading lines are also in figure 1.1 to show the variance and correlation among the 17 variables, as well as the loading on principal component axes one and two. The variables responsible for the most variation along each axis were difficult to determine because of the large number of variables; however, cations and anions generally had the longest loading lines and were in the direction of principal component axes one and two. The variables showing correlation were evaluated by observing the angle between loading lines ( 0 degrees is perfect positive correlation, 90 degrees is no correlation, and 180 degrees is perfect negative correlation). Variables within the same quadrant generally displayed positive correlation, and variables in the diagonal quadrants (quadrant I to III and II to IV) were negatively correlated. However, neighboring quadrants (I to II, II to III, III to IV, and IV to I) generally were uncorrelated.

The plotting positions of the sample sites in figure 1.1 show possible groupings and relations among sites sampled by the NPS in the 1980s. Most stream (sites ending with "Sw") and some spring samples plotted in quadrant I on figure 1.1, which indicated high values for loading line variables in quadrant I. Samples from wells completed in the upper Fort Union aquifer plotted exclusively in quadrant II with samples from Overlook Spring, and had high values of fluoride (F), carbonate $\left(\mathrm{CO}_{3}\right)$, sodium ratio ( $\mathrm{Na}$ ratio), and $\mathrm{pH}$. Most spring and some stream samples plotted in quadrants III and IV (fig. 1.1).
Sites that plotted in quadrant III showed low (opposite of loading lines in quadrant I) to intermediate (nearly 90 degrees to loading lines in quadrants II and IV) values of all input variables but were more similar to groundwater than streams (both negative along principal component axis one). Sites in quadrant IV were more similar to streams than groundwaterindicated by the opposite patterns from the upper Fort Union aquifer wells and placement on the positive side of the principal component one axis.

The $k$-means clustering procedure was applied to the PCA results to statistically group samples into clusters based on proximity in the PCA biplot. Figure 1.2 shows the results of the $k$-means procedure with cluster groups assigned numbers 1 through 5 and bounded by different colored circles. Table 1.1 summarizes the sample sites included in each cluster and provides a likely classification category. Group one contained mostly stream samples and all samples from Southeast Corner Spring (SU_SECrnSp; fig. 1.2). Group two contained North Unit stream samples, samples from Stevens Spring (NU_StvnSp) and Hagan Spring (NU_HgnSp), and a sample from Buck Hill Spring (BckHllSp; location unknown; fig. 1.2). Group three consisted of mostly South Unit wells completed in the upper Fort Union aquifer but also included all samples from Overlook Spring (NU_OvrlkSp) and samples from an unlocated well (Rough Rider well; fig. 1.2). Group four had mostly South Unit springs but also included samples from North Unit streams and samples from several unlocated stream and spring sites (fig. 1.2). Group five was a mixture of samples from North and South Unit springs and one sample from a South Unit stream site. Samples from Achenbach Spring (NU_ AchSp) and Hagan Spring (NU_HgnSp) in group five plotted close to group four (fig. 1.2).

Water sources for springs were inferred using the $k$-means procedure results. Samples from springs, streams, and wells generally were separated in the PCA plot with $k$-means clustering (fig. 1.2), but some spring samples plotted closer to groundwater or stream samples. Spring samples from group four that plotted close to group three (upper Fort Union aquifer) in figure 1.2 were inferred to be sourced mostly from groundwater. Surface-water samples in group three may have been from dry periods where upper Fort Union aquifer groundwater was the main source of water contributing to streamflow because they are more similar to groundwater samples than other stream samples. Samples from Overlook Spring were the only spring samples that plotted with group three because it is likely a well in a confined part of the upper Fort Union aquifer. Spring samples in groups 2 and 5 that plotted close to group one (stream samples) were inferred to be sourced mostly from streams and precipitation. Springs, however, likely were sourced from a mixture of groundwater, streams, 


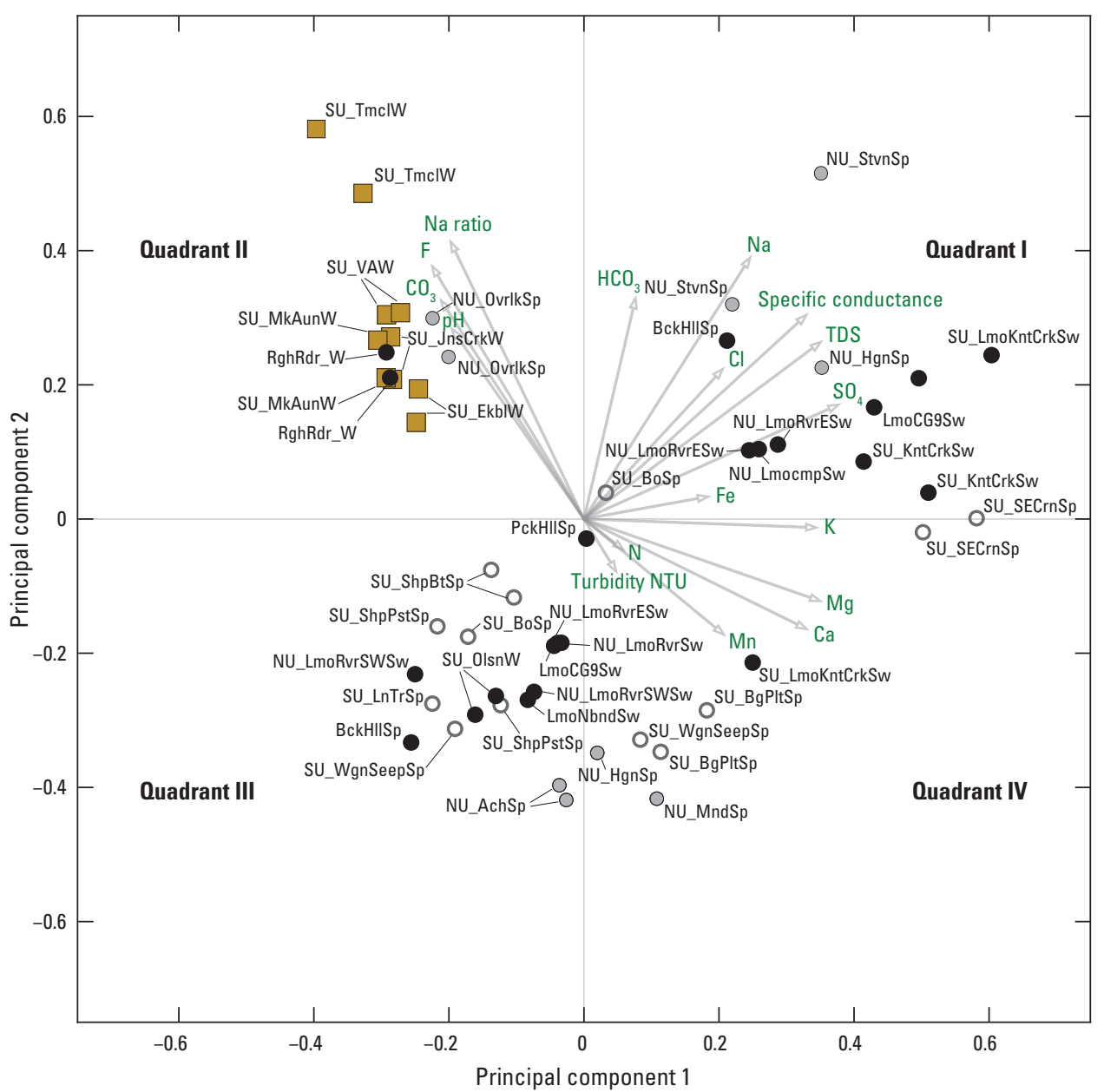

EXPLANATION

[Site names are listed in table $3 ; \mathrm{Ca}$, calcium; $\mathrm{Cl}$, chloride; $\mathrm{CO}_{3}$, carbonate; $\mathrm{F}$, fluoride; $\mathrm{Fe}$, iron; $\mathrm{HCO}_{3}$, bicarbonate; $\mathrm{K}$, potassium; $\mathrm{Mg}$, magnesium $\mathrm{Mn}$, manganese; N, nitrogen; $\mathrm{Na}$, sodium; NTU, nephelometric turbidity units; $\mathrm{SO}_{4}$, sulfate; TDS, total dissolved solids]

$\longrightarrow$ Loading lin

North Unit spring and identifier

O South Unit spring and identifier

$\square$ Upper Fort Union aquifer well and identifier

- Site location is unknown or not included in this study

pH Chemical constituent or physical property

Figure 1.1. Principal component analysis results for water chemistry collected during the 1980s by the National Park Service (National Park Service, 1997) with loading lines for each variable used in the analysis.

and precipitation because all spring samples-except from Overlook Spring_ _ plotted between groundwater and stream samples (precipitation samples were not collected; fig. 1.2). Samples from the same spring site could not be interpreted for seasonal variations because samples were collected once per year for each spring.

The $k$-means procedure results for data collected during 2018 as part of this study and during the 1980s by the NPS (1997) differed for some spring samples. The NPS (1997) data plotted several springs either closer to or further away from surface water and groundwater groups. Overlook Spring (NU_OvrlkSp) plotted with upper Fort Union aquifer groundwater samples in figure 1.2 but not in figure 12 for data collected in 2018 as part of this study. The biplot for NPS
(1997) data showed that Sheep Butte Spring (SU_ShpBtSp), Sheep Pasture Spring (SU_ShpPstSp), and Lone Tree Spring (SU_LnTrSp) differed from surface water, whereas the biplot for data collected during 2018 plotted them closer to surface water. Other springs_-like Stevens Spring (NU_StvnSp) and Hagan Spring (NU_HgnSp) - that were like upper Fort Union aquifer groundwater in the biplot for data collected during 2018 plotted opposite of upper Fort Union aquifer samples in the biplot of NPS (1997) data. The different results from the biplots for the two datasets could be from differences in the number and type of variables used to create the biplots. The $\delta^{2} \mathrm{H}$ and $\delta^{18} \mathrm{O}$ data collected during 2018 explained most of the variance along principal component axis one (fig. 12); however, the NPS (1997) data did not include $\delta^{2} \mathrm{H}$ and $\delta^{18} \mathrm{O}$ data. 


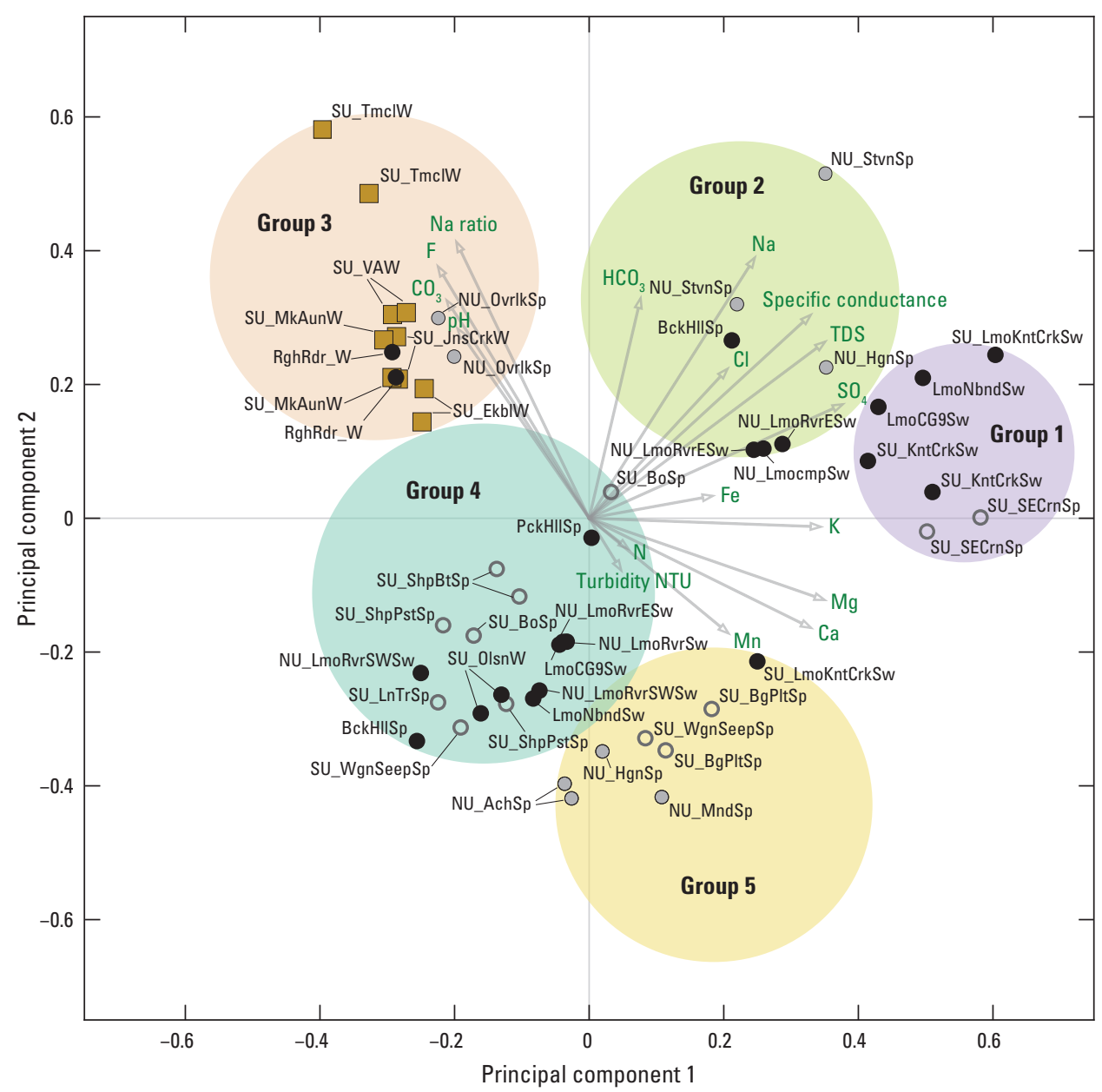

\section{EXPLANATION}

[Site names are listed in table $3 ; \mathrm{Ca}$, calcium; $\mathrm{Cl}$, chloride; $\mathrm{CO}_{3^{\prime}}$ carbonate; $\mathrm{F}$, fluoride; $\mathrm{Fe}$, iron; $\mathrm{HCO}_{3^{\prime}}$ bicarbonate; $\mathrm{K}$, potassium; $\mathrm{Mg}$, magnesium; $\mathrm{Mn}$, manganese; $\mathrm{N}$, nitrogen; $\mathrm{Na}$, sodium; NTU, nephelometric turbidity units; $\mathrm{SO}_{{ }^{\prime}}$, sulfate; TDS, total dissolved solids]

$\rightarrow$ Loading line

North Unit spring and identifier

O South Unit spring and identifier

$\square \quad$ Upper Fort Union aquifer well and identifier

- Site location is unknown or not included in this study

$\mathrm{pH}$ Chemical constituent or physical property

Figure 1.2. The $k$-means clustering procedure applied to principal component analysis results for water chemistry collected during the 1980 s by the National Park Service (National Park Service, 1997) with loading lines for each variable used in the analysis. 
Table 1.1. Summary of cluster analysis results from the $k$-means clustering procedure applied to principal component analysis results for water-chemistry data collected by the National Park Service in the 1980s (National Park Service, 1997).

[NU, North Unit; SU, South Unit; UL, unlocated or location unknown]

\begin{tabular}{|c|c|c|c|c|}
\hline Group & $\begin{array}{l}\text { Sample site from National Park Service } \\
\text { 1980s water-quality study }\end{array}$ & $\begin{array}{l}\text { Short name (table 3; } \\
\text { figs. 1.1 and 1.2) }\end{array}$ & $\begin{array}{c}\text { Number of samples } \\
\text { from the site in the } \\
\text { cluster }\end{array}$ & Category \\
\hline \multirow[t]{5}{*}{1} & NU Little Missouri River North Boundary & LmoNbndSw & 1 & \multirow{5}{*}{$\begin{array}{l}\text { Surface water and } \\
\text { springs }\end{array}$} \\
\hline & UL Little Missouri River Campground \#9 & LmoCG9Sw & 1 & \\
\hline & SU Little Missouri River at Knutson Creek & SU_LmoKntCrkSw & 1 & \\
\hline & SU Knuston Creek & SU_KntCrkSw & 2 & \\
\hline & SU Southeast Corner Spring & SU_SECrnSp & 2 & \\
\hline \multirow[t]{5}{*}{2} & NU Little Missouri River North Unit Campground & NU_LmocmpSw & 1 & \multirow{5}{*}{$\begin{array}{l}\text { Springs and sur- } \\
\text { face water }\end{array}$} \\
\hline & NU Little Missouri River North Unit East & NU_LmoRvrESw & 2 & \\
\hline & UL Buck Hill Spring & BckHllSp & 1 & \\
\hline & NU Stevens Spring & NU_StvnSp & 2 & \\
\hline & NU Hagan Spring & NU_HgnSp & 1 & \\
\hline \multirow[t]{7}{*}{3} & NU Overlook Spring & NU_OvrlkSp & 2 & \multirow{7}{*}{$\begin{array}{l}\text { Upper Fort Union } \\
\text { aquifer }\end{array}$} \\
\hline & SU Tomamichel Well & SU_TmclW & 2 & \\
\hline & SU Ekblom Well & SU_EkblW & 2 & \\
\hline & SU VA Well & SU_VAW & 2 & \\
\hline & SU Jones Creek Well & SU_JnsCrkW & 2 & \\
\hline & SU Mike Auney Well & SU_MkAunW & 2 & \\
\hline & UL Rougher Rider Well & RghRdrW & 2 & \\
\hline \multirow[t]{13}{*}{4} & NU Little Missouri River North Unit Southwest & NU_LmoRvrSWSw & 2 & \multirow{13}{*}{$\begin{array}{l}\text { Springs and sur- } \\
\text { face water }\end{array}$} \\
\hline & NU Little Missouri River North Unit East & NU_LmoESw & 1 & \\
\hline & NU Little Missouri River North Unit & NU_LmoRvrSw & 1 & \\
\hline & NU Little Missouri River North Boundary & LmoNbndSw & 1 & \\
\hline & UL Little Missouri River Campground \#9 & LmoCG9Sw & 1 & \\
\hline & SU Boicourt Spring & SU_BoSp & 2 & \\
\hline & SU Sheep Butte Spring & SU_ShpBtSp & 2 & \\
\hline & SU Sheep Pasture Spring & SU_ShpPstSp & 2 & \\
\hline & SU Lone Tree Spring & SU_LnTrSp & 1 & \\
\hline & SU Wannagan Seeps & SU_WgnSeepSp & 1 & \\
\hline & UL Buck Hill Spring & BckHllSp & 1 & \\
\hline & SU Olsen Well & SU_OlsnW & 2 & \\
\hline & UL Peck Hill Spring & PckHllSp & 1 & \\
\hline \multirow[t]{6}{*}{5} & SU Little Missouri River at Knutson Creek & SU_LmoKntCrkSw & 1 & \multirow[t]{6}{*}{ Springs and seeps } \\
\hline & NU Achenbach Spring & NU_AchSp & 2 & \\
\hline & NU Hagan Spring & NU_HgnSp & 1 & \\
\hline & NU Mandal Spring & NU_MndSp & 1 & \\
\hline & NU Big Plateau Spring & NU_BgPltSp & 2 & \\
\hline & SU Wannagan Seeps & SU_WgnSeepSp & 1 & \\
\hline
\end{tabular}




\section{References Cited}

Davis, J.C., 2002, Statistics and data analysis in geology $3 \mathrm{~d}$ ed.: Hoboken, New Jersey, John Wiley and Sons, Inc., $638 \mathrm{p}$.

National Park Service, 1997, Baseline water quality data inventory and analysis-Theodore Roosevelt National Park: National Park Service, Technical Report NPS/NRWRD/ NRTR-97/100, 499 p. 
For more information about this publication, contact: Director, USGS Dakota Water Science Center

821 East Interstate Avenue, Bismarck, ND 58503

1608 Mountain View Road, Rapid City, SD 57702

605-394-3200

For additional information, visit: https://www.usgs.gov/centers/dakota-water Publishing support provided by the Rolla Publishing Service Center 


\section{$\frac{\mathbb{2}}{\mathrm{C}}$}

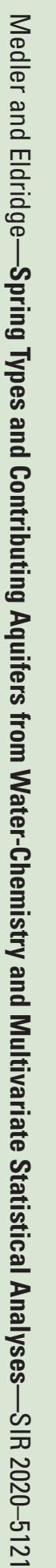

